\title{
Both Granulocytic and Non-Granulocytic Blood Cells Are Affected in Patients with Severe Congenital Neutropenia and Their Non- Neutropenic Family Members: An Evaluation of Morphology, Function, and Cell Death
}

Ciddi Konjenital Nötropenisi Olan Hastalarda ve Nötropenik Olmayan Ebeveynlerinde Hem Granülositik Hem Granülositik Olmayan Kan Hücreleri Etkilenir: Morfoloji, Fonksiyon ve Hücre Ölümü Yönünden Bir Değerlendirme

\footnotetext{
(D) Lale Olcay1, (D) Şule Ünal2, (D) Hüseyin Onay33, (D) Esra Erdemli4, (D) Ayşenur Öztürk5, (D) Deniz Billur6, (D) Ayşe Metin7, (D) Hamza Okur², (D) Yıldız Yıldırmak , (D) Yahya Büyükaşık ${ }^{9}$, (D) Aydan İkincioğulları10, (D) Mesude Falay11, (D) Gülsüm Özet11,12, (D) Sevgi Yetgin²

${ }^{1}$ Ankara Oncology Training and Research Hospital, Clinic of Pediatric Hematology, Ankara, Turkey

2 Hacettepe University Faculty of Medicine, ihsan Doğramacı Children's Hospital, Clinic of Pediatric Hematology, Ankara, Turkey

${ }^{3}$ Ege University Faculty of Medicine, Department of Medical Genetics, Izmir, Turkey

${ }^{4}$ Ankara University Faculty of Medicine, Department of Histology Embryology, Ankara, Turkey

${ }^{5}$ Ankara University Faculty of Medicine, Department of Pediatric Molecular Genetics, Ankara, Turkey

${ }^{6}$ Ankara University Faculty of Medicine, Department of Histology Embryology, Ankara, Turkey

${ }^{7}$ Ankara Children's Hematology Oncology Training and Research Hospital, Clinic of Pediatric Immunology, Ankara, Turkey

8Şişli Etfal Children's Training and Research Hospital, Clinic of Pediatric Hematology, İstanbul, Turkey

9 Hacettepe University Faculty of Medicine, Department of Internal Medicine, Unit of Hematology, Ankara, Turkey

${ }^{10}$ Ankara University Faculty of Medicine, Department of Pediatric Immunology and Allergy and Pediatric Molecular Genetics, Ankara, Turkey

${ }^{11}$ Ankara Numune Training and Research Hospital, Clinic of Hematology, Ankara, Turkey

12 Yıldırım Beyazıt University Faculty of Medicine, Department of Internal Medicine, Clinic of Hematology, Ankara, Turkey
}

\section{Abstract}

Objective: To examine granulocytic and non-granulocytic cells in children with severe congenital neutropenia $(\mathrm{SCN})$ and their nonneutropenic parents.

Materials and Methods: Fifteen patients with SCN and 21 nonneutropenic parents were evaluated for a) CD95, CD95 ligand, annexin $V$, propidium iodide, cell cycle, and lymphocyte subsets by flow cytometry; b) rapid cell senescence (of leukocytes) by senescenceassociated $\beta$-galactosidase stain; c) aggregation tests by aggregometer; d) in vitro bleeding time by PFA-100 instrument; e) mepacrine-labeled dense granule number of thrombocytes by fluorescence microscope; and f) hematomorphology by light and electron microscope. $H A X 1$, ELANE, G6PC3, CSF3R, and JAGN1 mutations associated with SCN were studied in patients and several parents.

\begin{abstract}
IIII
Amaç: Ciddi konjenital nötropenisi (CKN) olan hastalar ve nötropenik olmayan ebeveynlerindeki granülositik ve granülositik olmayan kan hücrelerini incelemektir.

Gereç ve Yöntemler: CKN'si olan 15 çocuk ve nötropenik olmayan 21 ebeveynin lenfosit, granülosit ve monositlerinde CD95, CD95 ligand, annexin $\mathrm{V}$, hücre siklusu (periferik lenfositler, granülosiler +/monositlerde) ve lenfosit alt grupları akım sitometri ile, b) hızlı hücre yaşlanması (lökositlerde) yaşlanma-ilişkili $\beta$-galaktozidaz boyası SA$\beta$-galaktosidaz boyası ile, c) agregasyon testleri agregometre ile, $d$ ) in vitro kanama zamanı, PFA-100 aleti ile, e) trombositlerde mepakrin işaretli kaba granül sayısı floresan mikroskopu ile, f) hematomorfoloji ışık ve elektron mikroskopu ile değerlendirildi. Hastalarda ve bazı ebeveynlerde CKN ile ilişkili olarak HAX1, ELANE, G6PC3, CSF3R, JAGN1 mutasyonları çalışıldı.
\end{abstract}


Results: Significant increase in apoptosis and secondary necrosis in monocytes, lymphocytes, and granulocytes of the patients and parents was detected, irrespective of the mutation type. CD95 and CD95 ligand results implied that apoptosis was non-CD95mediated. Leukocytes of $25 \%, 12.5 \%$, and $0 \%$ of patients, parents, and controls showed rapid cell senescence. The cell cycle analysis testable in four cases showed $\mathrm{G} 1$ arrest and apoptosis in lymphocytes of three. The patients had HAX1 $(n=6), \operatorname{ELANE}(n=2), \operatorname{G6PC3}(n=2)$, and unidentified $(n=5)$ mutations. The CD3, CD4, and NK lymphocytes were below normal levels in $16.6 \%, 8.3 \%$, and $36.4 \%$ of the patients and in $0 \%, 0 \%$, and $15.4 \%$ of the parents (controls: $0 \%, 0 \%, 5.6 \%$ ). The thrombocytes aggregated at low rates, dense granule number/ thrombocyte ratio was low, and in vitro bleeding time was prolonged in $37.5 \%-66.6 \%$ of patients and $33.3 \%-63.2 \%$ of parents (vs. $0 \%$ in controls). Under electron and/or light microscope, the neutrophils, monocytes, lymphocytes, and thrombocytes in the peripheral blood of both patients and parents were dysplastic and the bone marrow of patients revealed increased phagocytic activity, dysmegakaryopoiesis, and necrotic and apoptotic cells. Ultrastructurally, thrombocyte adhesion, aggregation, and release were inadequate.

Conclusion: In cases of SCN, patients' pluripotent hematopoietic stem cells and their non-neutropenic parents are both affected irrespective of the genetic defect.

Keywords: Severe congenital neutropenia, Monocytes, Lymphocytes, NK cells, Thrombocytes, Phagocytes, Apoptosis, Senescence, Parents, Family
Bulgular: Akım sitometri ile, hasta ve ebeveynlerinin monosit, lenfosit ve granülositlerinde apoptoz ve sekonder nekrozda belirgin artış olduğu ve bunun konjenital nötropeni mutasyonunun cinsi ile ilişkili olmadığı gösterildi. CD95 ve CD95 ligand sonuçları, apoptozun CD95 yolu ile olmadığını gösteriyordu. Hasta, ebeveyn ve kontrol olgularının lökositlerinin \%25, \%12,5 ve \% $\%$ ' SA- $\beta$-gal boyası ile boyandı. Dört olguda yapılabilen hücre siklusu analizinde üç olgunun lenfositlerinde $\mathrm{G} 1$ arresti ve apoptoz görüldü. Hastalarda $\operatorname{HAX} 1(\mathrm{n}=6)$; ELANE $(n=2) ; \operatorname{G6PC3}(n=2)$ ve belirlenemeyen $(n=5)$ mutasyonlar saptandı. CD3, CD4 ve NK lenfositleri sırasıyla hastaların $\% 16,6$; $\% 8,3 ; \% 36,4$ 'ünde, ebeveynlerin $\% 0, \% 0 \% 15,4$ 'ünde, kontrolün $\% 0, \% 0, \% 5,6$ 'sında yaşa göre normal aralığın altında idi. Hasta ve ebeveynlerin trombositleri düşük oranda agrege oluyordu (olguların sırasıyla \%66,6 ve \%63,2'sinde, kontrolün \%0'ında), kaba granül sayısı/trombosit oranı düşük (hasta, ebeveyn ve kontrolün \%50, \%35 ve $\% 0$ 'ında); in vitro kanama zamanı uzun (farklı kartuşlarla olguların $\% 37,5$ ve $\% 33,3$ 'ünde ve ebeveynlerin $\% 18,8$ ve $\% 12,5$ 'inde) idi. Işık ve elektron mikroskopta hasta ve ebeveynlerin periferik kanlarındaki nötrofil, monosit, lenfosit ve trombositleri displastik idi; hastaların kemik iliğinde fagosit aktivitesinde artış, dismegakaryopoez, nekrotik ve apoptotik hücreler bulunuyordu. İnce yapısal olarak trombositlerde adezyon, agregasyon, salınım yetersiz idi.

Sonuç: CKN'de, pluripotent hematopoietik kök hücreler ve nötropenik olmayan ebeveynleri genetik bozukluktan bağımsız olarak etkilenirler.

Anahtar Sözcükler: Ciddi kongenital nötropeni, Monositler, Lenfositler, Trombositler, Fagositler, Apoptoz, Yaşlanma, Ebeveyn, Aile

\section{Introduction}

Severe congenital neutropenia ( $\mathrm{SCN}$ ) is a heterogeneous bone marrow failure syndrome characterized by recurrent infections, low absolute neutrophil count $\left(<0.5 \times 10^{9} / \mathrm{L}\right)$, and maturation arrest at the promyelocyte/myelocyte stage of myelopoiesis in the vast majority of cases and it is due to various genetic defects $[1,2,3]$. Regular variations [4], giving rise to transient elevations of neutrophil counts to even $>1.5 \times 10^{9} / \mathrm{L}$ with 'intermittent maturation arrest' [5], can be encountered.

Apoptosis in neutrophilic precursors plays a major role in the pathogenesis of SCN $[1,2,6]$. Reports regarding lymphocyte apoptosis in addition to granulocyte apoptosis have been restricted to a few cases $[7,8]$, and apoptosis in monocytes has not been studied. Reports pertaining to non-granulocytic blood cell lines in SCN and patients' non-neutropenic family members are also too limited $[3,7,8,9,10]$ to make a general characterization of the phenotype of SCN cases with heterogeneous genetic backgrounds.

We have hypothesized that, in $\mathrm{SCN}$, development of all cell lines other than the granulocytic lineage is also impaired and patients' non-neutropenic parents also carry some hematologic abnormalities. Our specific aim in this study is to examine the lymphocytes, monocytes, and granulocytes of patients with SCN and their family members in terms of morphology and cell death parameters [apoptosis and rapid cell senescence (RCS)] and additionally to evaluate thrombocyte morphology and functions and percentage of lymphocyte subsets.

\section{Materials and Methods}

\section{Study Participants}

Severe congenital neutropenia was defined as persistent neutropenia (neutrophil counts of $<0.5 \times 10^{9} / \mathrm{L}$ ) confirmed from two samples a week for 6 weeks and the onset of neutropenia or infections early in life and deficiency in late maturation stages of neutrophils in bone marrow (mature neutrophils being $<10 \%$ : central neutropenia) [4]. However, subjects whose neutrophils showed some spontaneous variations between $<0.5 \times 10^{9} / \mathrm{L}$ and $1.5 \times 10^{9} / \mathrm{L}$ were not excluded [4]. Those with syndromic neutropenia were excluded.

Fifteen children with SCN [age: $9.35 \pm 4.54$ years; range: 1.5 22; 8 female (F), 7 male (M)] and 21 non-neutropenic family members (10 mothers, 11 fathers; age: $35.14 \pm 8.92$ years; range: 23-55) were included in the study. A 22-year-old female was included since she had been followed in Pediatrics for 8 years.

Patients were prescribed G-CSF (5-25 $\mu \mathrm{g} / \mathrm{kg} /$ day), 2-7 times weekly; however, many patients received therapy irregularly for economic and social reasons. Blood was drawn during periods in which patients had stopped therapy and patients and family members had not consumed any other drugs for at least 10 days 


\begin{tabular}{|c|c|c|c|c|c|c|c|c|c|c|c|}
\hline & 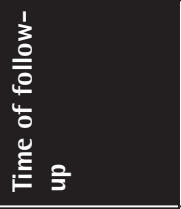 & 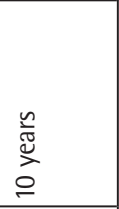 & 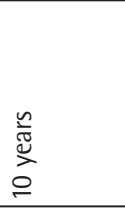 & 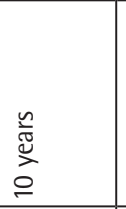 & 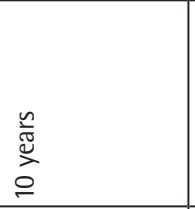 & 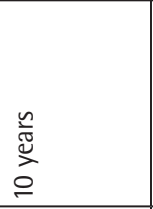 & 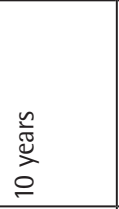 & $\begin{array}{l}\frac{\tilde{\omega}}{\bar{J}} \\
\stackrel{\sigma}{\sigma}\end{array}$ & $\begin{array}{l}\frac{\omega}{\bar{\varpi}} \\
\stackrel{\sigma}{\sigma} \\
\end{array}$ & 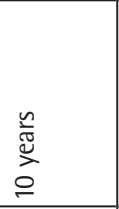 & 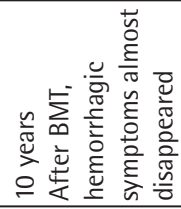 \\
\hline & 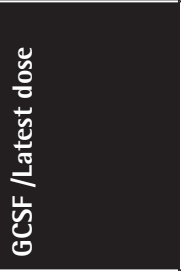 & 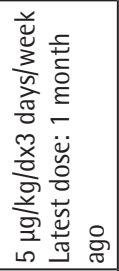 & 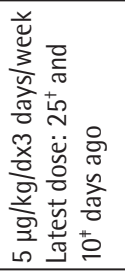 & 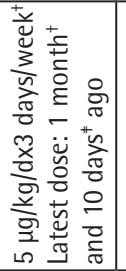 & 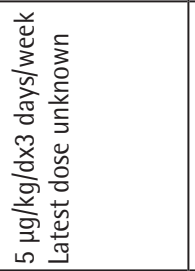 & 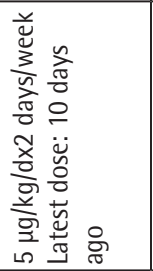 & 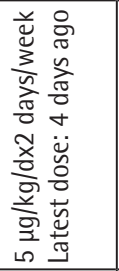 & $\begin{array}{l}\text { 剀 } \\
\vdots \\
0 \\
0 \\
2\end{array}$ & 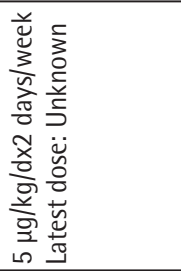 & 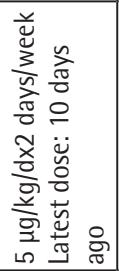 & 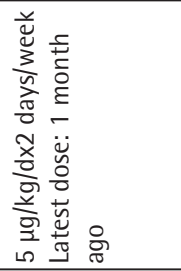 \\
\hline & 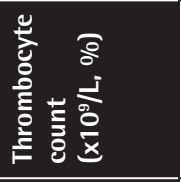 & 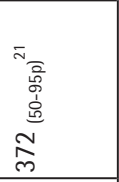 & 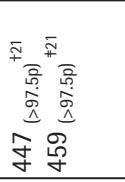 & 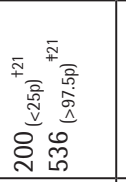 & 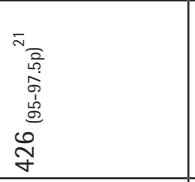 & 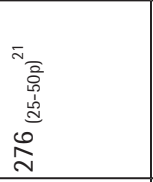 & 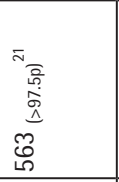 & 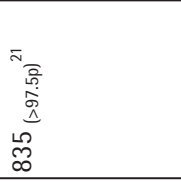 & 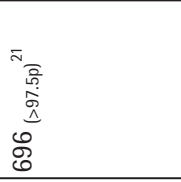 & 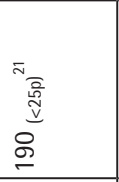 & 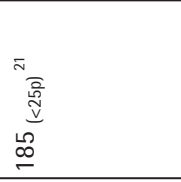 \\
\hline & 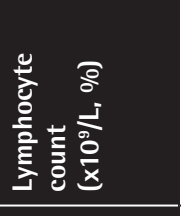 & 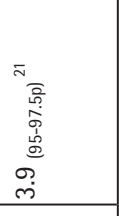 & 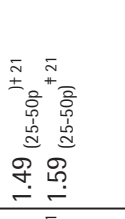 & 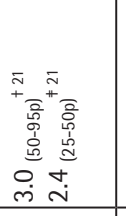 & 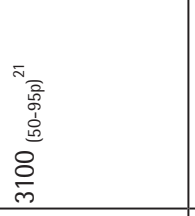 & 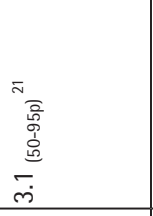 & 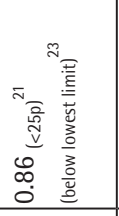 & 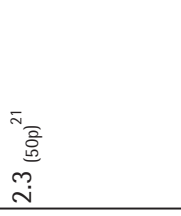 & 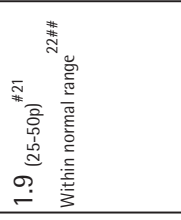 & 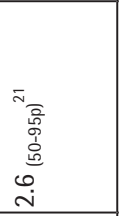 & 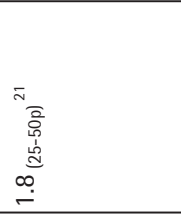 \\
\hline & 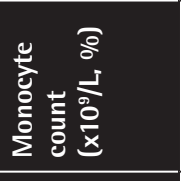 & 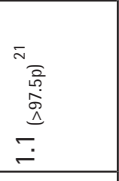 & 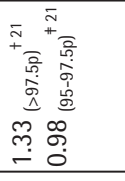 & 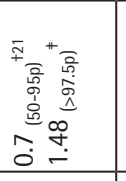 & 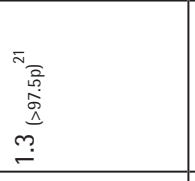 & 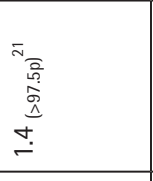 & 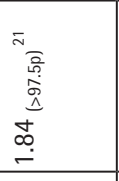 & 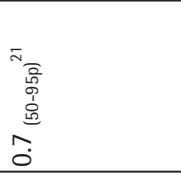 & 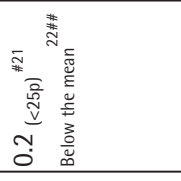 & 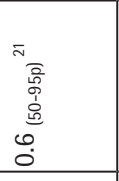 & 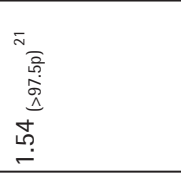 \\
\hline & 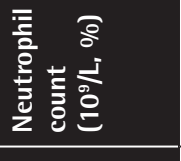 & $\stackrel{\llcorner}{0}$ & t & 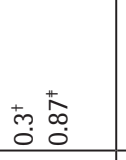 & $\stackrel{0}{0}$ & $\stackrel{+}{0}$ & $\stackrel{2}{0}$ & $\stackrel{\leftrightarrow}{\circ}$ & ชี & $\stackrel{+}{0}$ & $\begin{array}{l}0 \\
0 \\
0\end{array}$ \\
\hline & 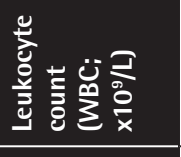 & 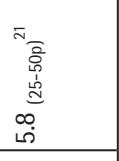 & 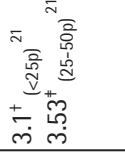 & 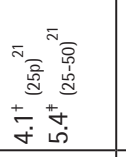 & 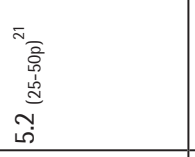 & 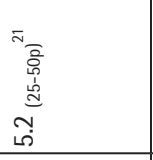 & 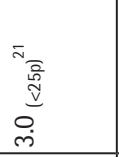 & 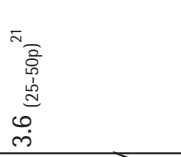 & 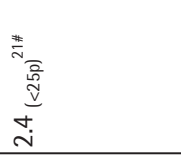 & 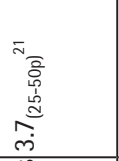 & 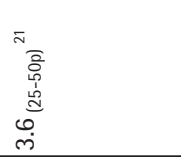 \\
\hline & 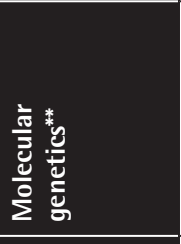 & 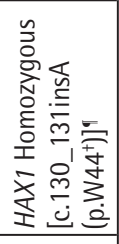 & 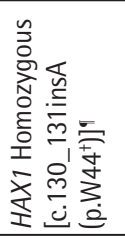 & 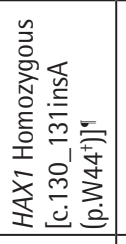 & 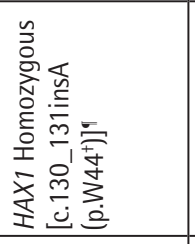 & 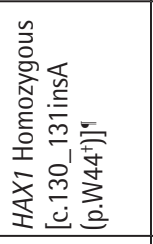 & 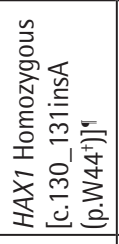 & 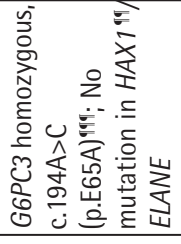 & 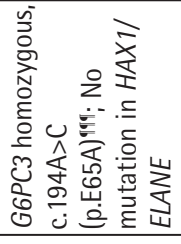 & 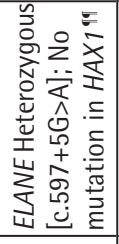 & 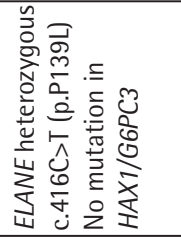 \\
\hline 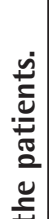 & 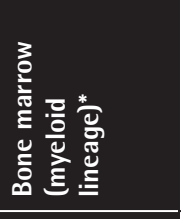 & 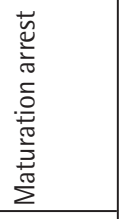 & 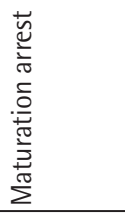 & 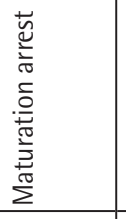 & 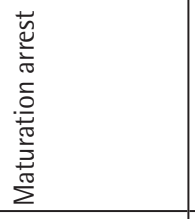 & 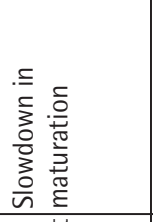 & 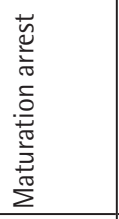 & 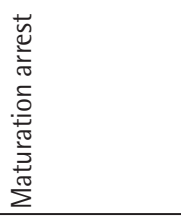 & 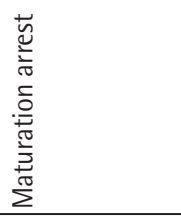 & 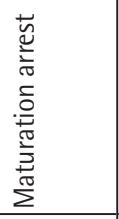 & 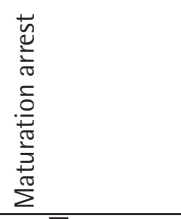 \\
\hline 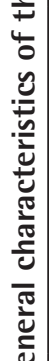 & 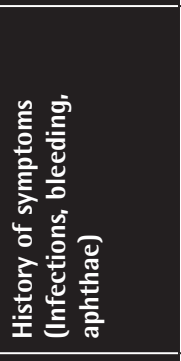 & 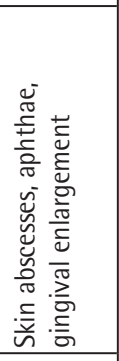 & 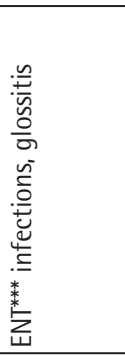 & 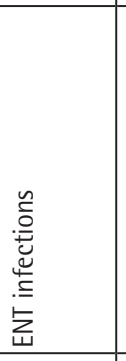 & 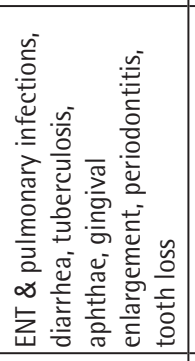 & 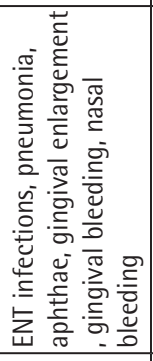 & 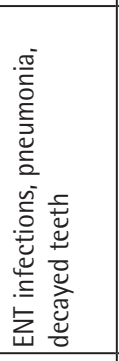 & 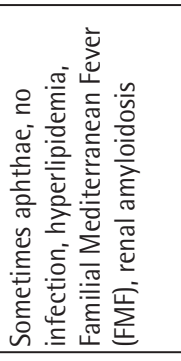 & 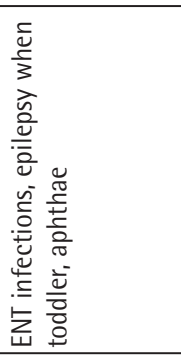 & 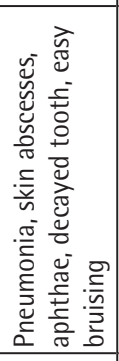 & 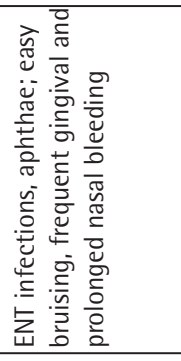 \\
\hline 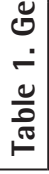 & 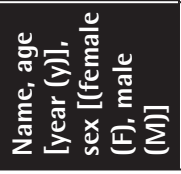 & 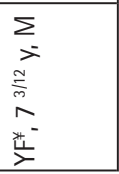 & 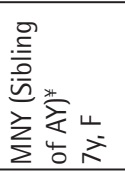 & 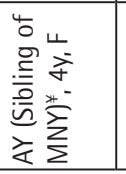 & $\begin{array}{l}u \\
\text { aे } \\
\check{\Sigma} \\
\dot{\Sigma}\end{array}$ & 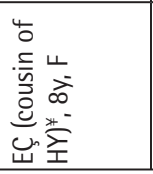 & 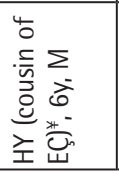 & 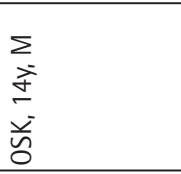 & 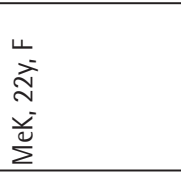 & 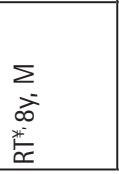 & 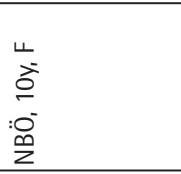 \\
\hline
\end{tabular}




\begin{tabular}{|c|c|c|c|c|c|c|c|}
\hline & 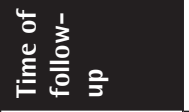 & 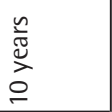 & 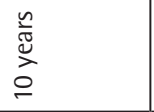 & \begin{tabular}{|l}
$n$ \\
$\frac{n}{\pi}$ \\
$\tilde{J}$ \\
0 \\
\end{tabular} & 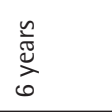 & 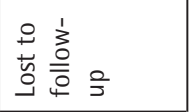 & 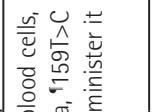 \\
\hline & 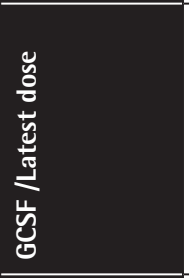 & 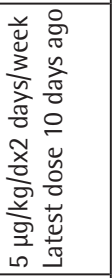 & $\begin{array}{l}\text { 峲 } \\
0 \\
0 \\
0 \\
\end{array}$ & 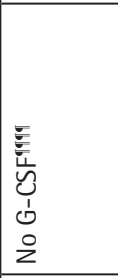 & 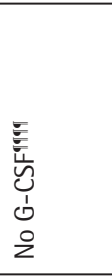 & 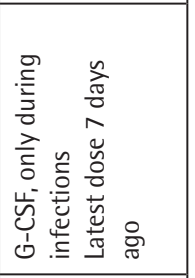 & 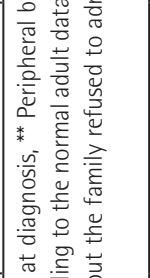 \\
\hline & 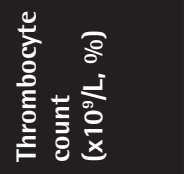 & 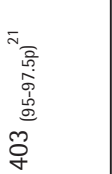 & 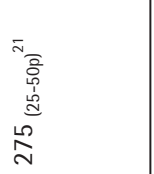 & 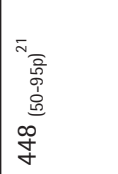 & 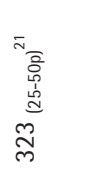 & 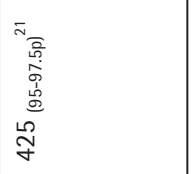 & 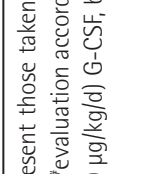 \\
\hline & 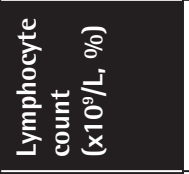 & 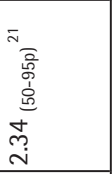 & 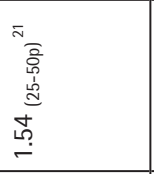 & 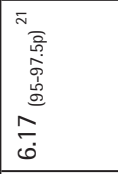 & 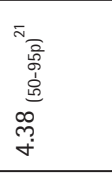 & 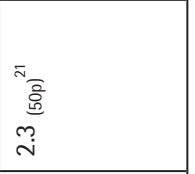 & 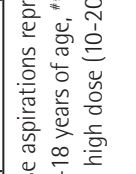 \\
\hline & 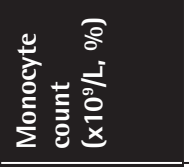 & 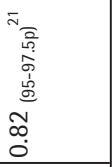 & 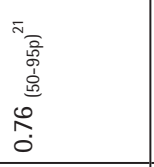 & 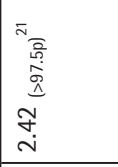 & 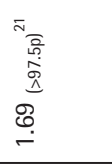 & 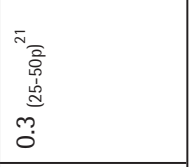 & 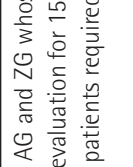 \\
\hline & 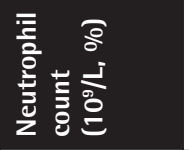 & 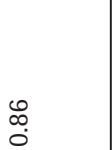 & $\begin{array}{l}\stackrel{0}{0} \\
\tilde{0}\end{array}$ & ปั. & $\underset{0}{J}$ & テุ & 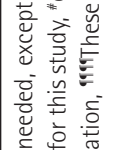 \\
\hline & 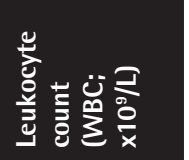 & 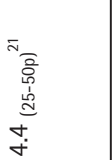 & 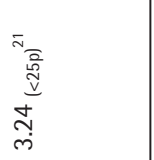 & 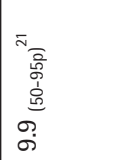 & 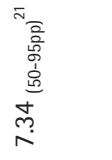 & 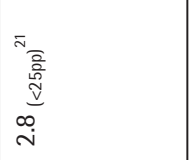 & 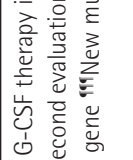 \\
\hline & 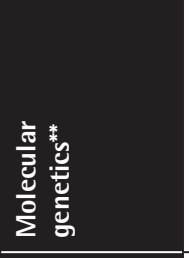 & 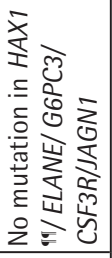 & 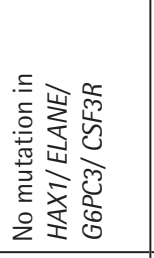 & 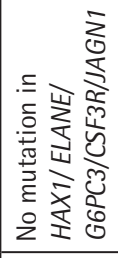 & 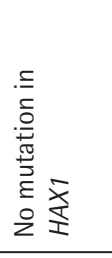 & 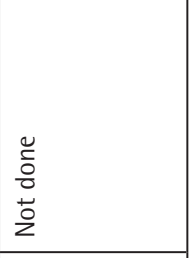 & 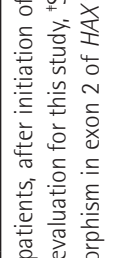 \\
\hline & 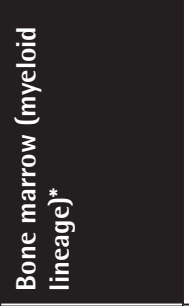 & 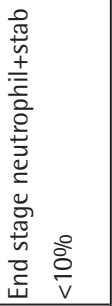 & 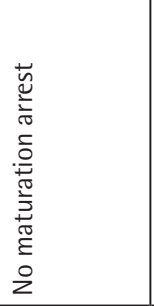 & 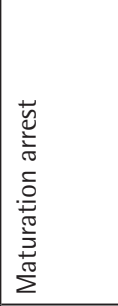 & 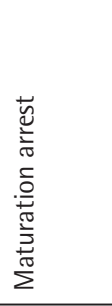 & 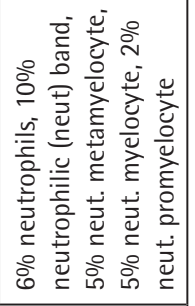 & 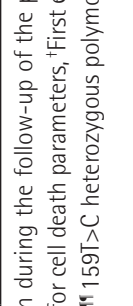 \\
\hline & 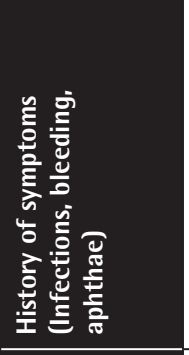 & : & 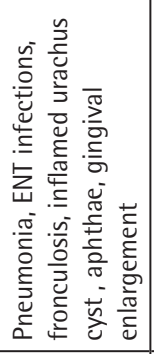 & 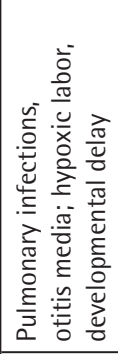 & 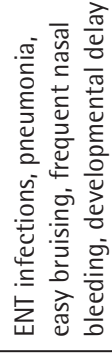 & 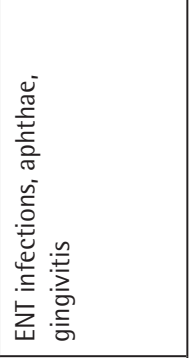 & 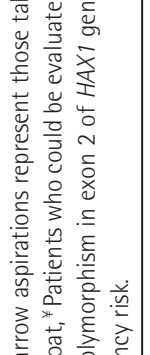 \\
\hline$\because$ & 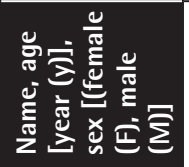 & $\begin{array}{l}\sum \\
\grave{\beth}\end{array}$ & 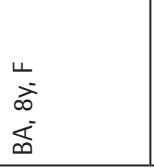 & 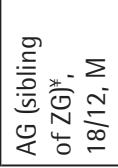 & 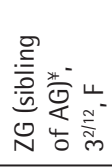 & $\begin{array}{l}\sum \\
\grave{d} \\
\frac{\Sigma}{\sin } \\
\end{array}$ & 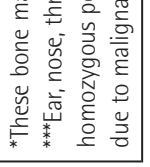 \\
\hline
\end{tabular}

prior to samples being taken to eliminate drug effects on thrombocyte aggregation [11].

For lymphocyte subsets, death parameters (CD95, CD95 ligand, annexin V), dysmorphism, thrombocyte aggregation tests, mepacrine labeling, and in vitro bleeding time, 18, 10, 9, 5,5 , and 9 healthy volunteers were evaluated, respectively. For evaluation of lymphocyte subsets, age-matched normal ranges for healthy Turkish children [12] and our laboratory for adults were used.

\section{Flow Cytometric Evaluation}

Peripheral blood was prepared for flow cytometric analysis as reported previously $[8,13,14]$ by direct immunofluorescence (FAC Scan, Becton Dickinson CA and Beckman Coulter, USA). By combining CD45 and CD14 with the forward and right-angle light scatter parameters of blood cells, the lymphocytes, granulocytes, and monocytes were gated (Figure 1A). CD95, CD95 ligand, and annexin $V$ were evaluated in each gate; the CD3, CD4, CD8, and NK cells were evaluated in the lymphocyte gates $[13,14]$. Kits from Biosciences (USA) (for CD95 and CD95 ligand) and Pharmingen (USA) [for annexin $\mathrm{V}$, propidium iodide $(\mathrm{PI}), 7$-aminoactinomycin $\mathrm{D}$ (7-AAD), and CD3, CD4, CD8, and NK cells] were used. Per sample, 10,000 cells were counted. The cell cycles of the lymphocytes and granulocytes were evaluated by the PI florescence histogram method [13].

\section{Rapid Cell Senescence}

The leukocytes were stained for senescenceassociated $\beta$-galactosidase (SA- $\beta$-gal kit, Sigma Co., Germany) as per the manufacturer's protocols [15].

\section{Mutation Analysis}

Mutation analyses of HAX1, ELANE, CSF3R, G6PC3, and JAGN1 genes were performed by standard techniques (Supplemental Materials and Methods and Supplemental Table 1).

\section{Evaluation of Cellular Morphology}

The peripheral blood cells were evaluated by light (Nikon E400) and transmission electron microscopy (TEM) (LEO 906E) for apoptosis and dysplasia $[8,10,14,16,17]$, in a blinded fashion (Supplemental Materials and Methods). The 
bone marrow aspiration smears taken at admission were also evaluated under light microscope. Bone marrow aspiration of the parents could not be performed.

\section{Evaluation of the Thrombocytes of the Patients and the Parents}

In vitro bleeding time was measured with a PFA-100 instrument (Dade Behring Marburg GmbH, Marburg, Germany) [18] and turbidimetric aggregation tests were measured with a ChronoLog $560 \mathrm{Ca}$ aggregometer (Chrono-Log Corporation, Havertown, PA, USA) [18].

Dense granules were stained with mepacrine $(1 \mu \mathrm{M}$, Sigma, St. Louis, MO, USA) $[19,20]$ and thrombocytes were prepared for electron microscopic visualization of aggregation [19], as described previously (Supplemental Materials and Methods).

\section{Statistics Analysis}

We used SPSS 15.0 (SPSS Inc., Chicago, IL, USA) to evaluate the data we obtained. A normality test was performed to determine if the data were distributed in a normal fashion (Supplemental Materials and Methods).

\section{Results}

\section{History and Physical Examination}

In our cohort, there were three pairs of siblings and one pair of cousins, one having coexistent amyloidosis and hypercholesterolemia and the other having hemoglobin C. Their vaccines were administered on time without any complications. Parents of 14 patients were $1^{\text {st }}(n=10)$ or $2^{\text {nd }}$ $(n=4)$ degree relatives. The patients had gingival hypertrophy, aphthous stomatitis, decayed teeth, and tooth loss by $26.6 \%, 20 \%, 20 \%$, and $13.3 \%$, respectively. None had any physical malformation. Several patients had monocytosis and thrombocytosis $[21,22]$. The immunoglobulin (Ig) A, G, and $M$ levels of patient $A G$ and the $\lg G$ of patient $Z G$ were higher than normal, while the levels of all the other patients were normal. Four out of $15 \mathrm{SCN}$ patients (26.6\%) and 5 of 21 parents $(23.8 \% ; 3$ mothers, 2 fathers) had frequent nasal bleeding and easy bruising with/without menorrhagia. Investigations of immunoglobulin levels, which could be performed for ten parents, revealed normal results. The other characteristics of the patients and parents are presented in Table 1 and Supplemental Table 2.

\section{Flow Cytometric Evaluation}

Percentage of apoptotic cells, necrotic cells, and dead cells (apoptotic + necrotic) in the lymphocyte, granulocyte, and monocyte gates of both the patients and the parents were higher than those of the healthy controls, while they were similar among the patients and parents (Figure 1). CD95 and
CD95 ligand results were inconsistent with each other, implying that apoptosis was non-CD95-mediated (Table 2; Figure 1).

The CD3, CD4, and NK cells were below the age-matched normal ranges in $16.6 \%, 8.3 \%$, and $36.4 \%$ of the patients and $0 \%, 0 \%$, and $15.4 \%$ of the parents versus $0 \%, 0 \%$, and $5.6 \%$ of the controls. On the other hand, CD3 and CD8 cells were found to be above the age-matched normal ranges in 16.6\% and $27.3 \%$ of the patients and in $0 \%$ and $7.7 \%$ of the parents versus $0 \%$ and $16.7 \%$ of the controls (Supplemental Table 3).

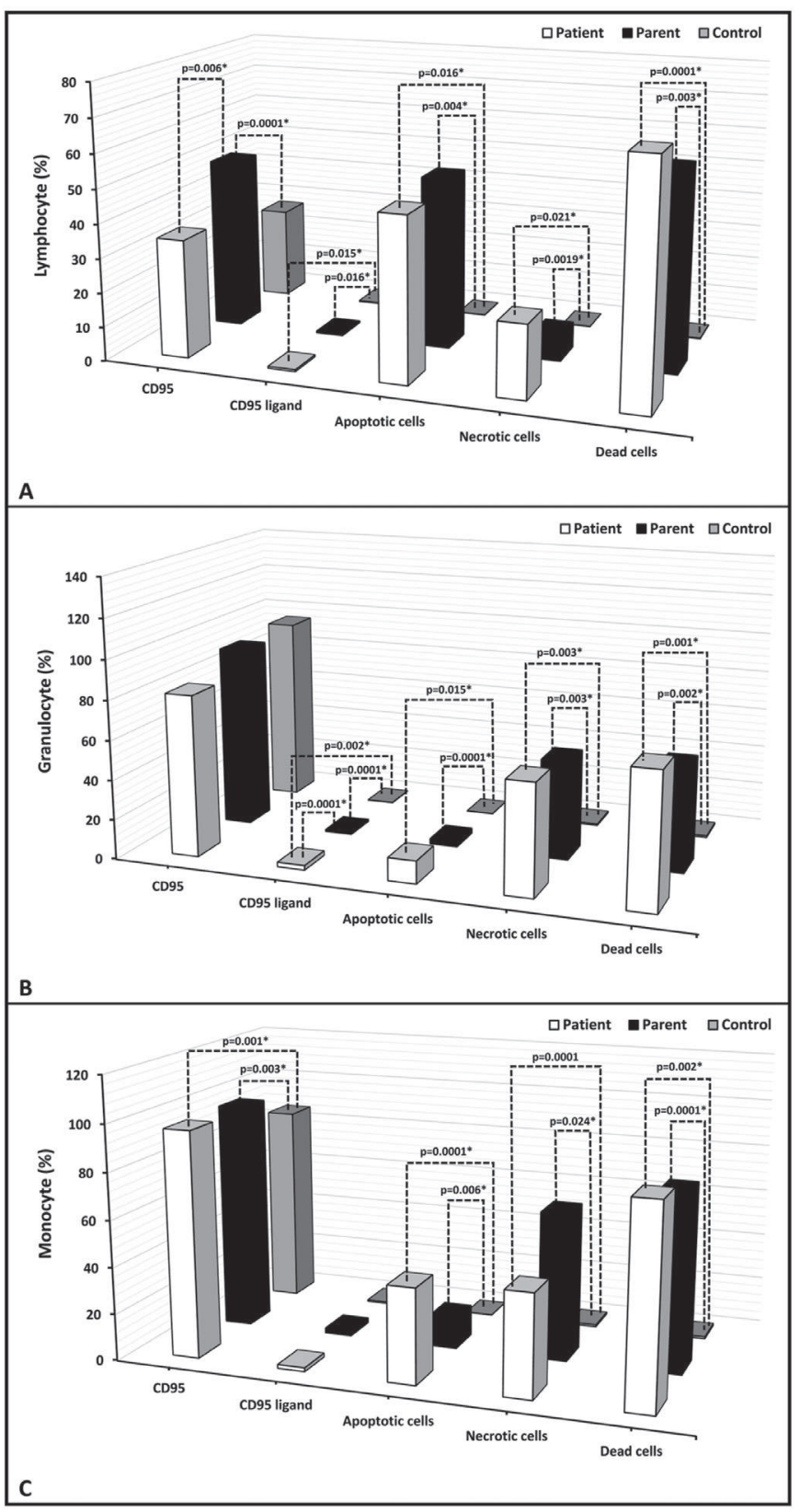

Figure 1. Percentage of CD95, CD95 ligand, annexin (showing apoptotic cells), propidium iodide (PI), or 7-aminoactinomycin D (7-AAD) (showing necrotic cells) and overall dead cells (apoptotic + necrotic cells) in lymphocyte, monocyte, and granulocyte gates. 


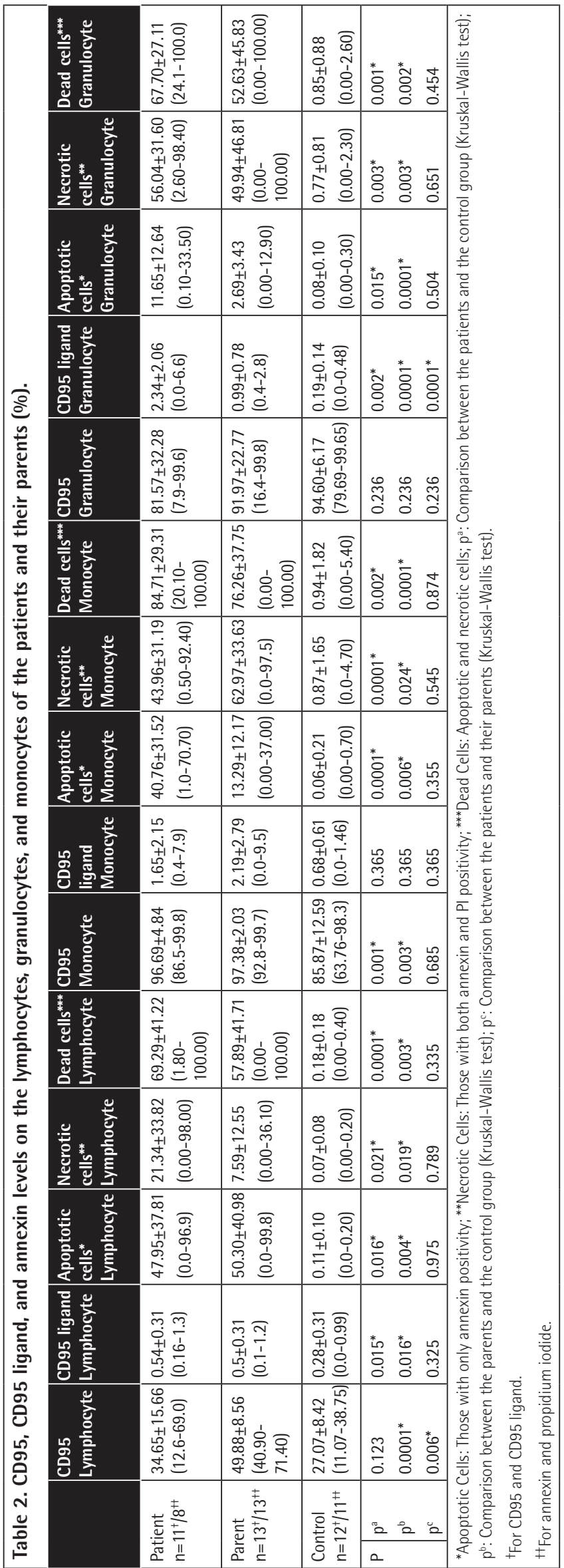

G1 arrest and apoptosis were established in one patient's lymphocytes (ZG) and those of her parents while the cell cycle of lymphocytes in the sibling of ZG (patient AG) was normal. The cell cycles of the parents' granulocytes were normal (Figures 3A-3F).

\section{Rapid Cell Senescence}

Eight patients and eight parents were evaluated. The leukocytes of only 2 patients (siblings $A G$ and $Z G$ ) and their mother were stained with SA- $\beta$-gal by $88 \%, 76 \%$, and $94 \%$, respectively (Figures $3 \mathrm{G}, 3 \mathrm{H}$, $31)$. These patients were members of a family and were evaluated for cell cycles at the same time (Figures 3A-3F).

\section{Cell Morphology}

\section{Neutrophils}

The incidences of bizarre nuclei $(34.0 \pm 17.4 \%$ vs. $15.2 \pm 4.7 \%$, $\mathrm{p}=0.015)$, pseudo Pelger-Huet (PPH) and PPH-like cells $(15.7 \pm 9.3$ vs. $4.1 \pm 3.3, p=0.003)$, striking chromatin clumping $(38.1 \pm 27.7 \%$ vs. $11.0 \pm 9.7 \%, p=0.036$ ), macropolycyte percentage (diameter $\geq 15$ $\mu \mathrm{m})(38.71 \pm 27.46 \%$ vs. $6.44 \pm 6.00 \%, p=0.0001)$ of neutrophils, and neutrophil diameter $(13.46 \pm 1.76$ vs. $9.79 \pm 1.73, p=0.0001)$ were significantly higher in the neutrophils of the parents than those of the control group by light microscope.

The few neutrophils of the patients in their peripheral blood and bone marrow also revealed the same abnormalities, but no scoring could be done due to the low number.

Ultrastructural study of the patients and parents revealed that secondary granules of neutrophils were low in number, primary granules were heterogeneous in shape and size, and chromatin clumping and apoptosis were striking (Figures 4D, 4E, 4L, 5D, 5E, and $5 \mathrm{H})$.

\section{Lymphocytes}

The peripheral lymphocytes of both patients and parents revealed few lymphocytes with tiny cytoplasmic protrusions. Ultrastructural study of peripheral blood of patients and parents showed that the lymphocytes were abnormal or active (Figures $4 G, 5 F$, and $5 G$ ).

\section{Monocytes, Macrophages, Histiocytes, and Other Phagocytes}

The peripheral blood of patients and parents revealed monocytes with features of apoptosis, abnormal nucleus, necrosis, or pseudopod formation under light microscope and abnormal mononuclear cells under TEM with or without features of apoptosis (Figures $4 \mathrm{~F}$ and $5 \mathrm{H}$ ).

The bone marrow examination of the patients revealed many monocytes, macrophages, histiocytes, neutrophils, bands, eosinophils, and eosinophil myelocytes undergoing phagocytosis. Sea blue-like and Gaucher-like histiocytes in the bone marrow of the patients were striking. The phagocytosed cells were lymphocytes, 


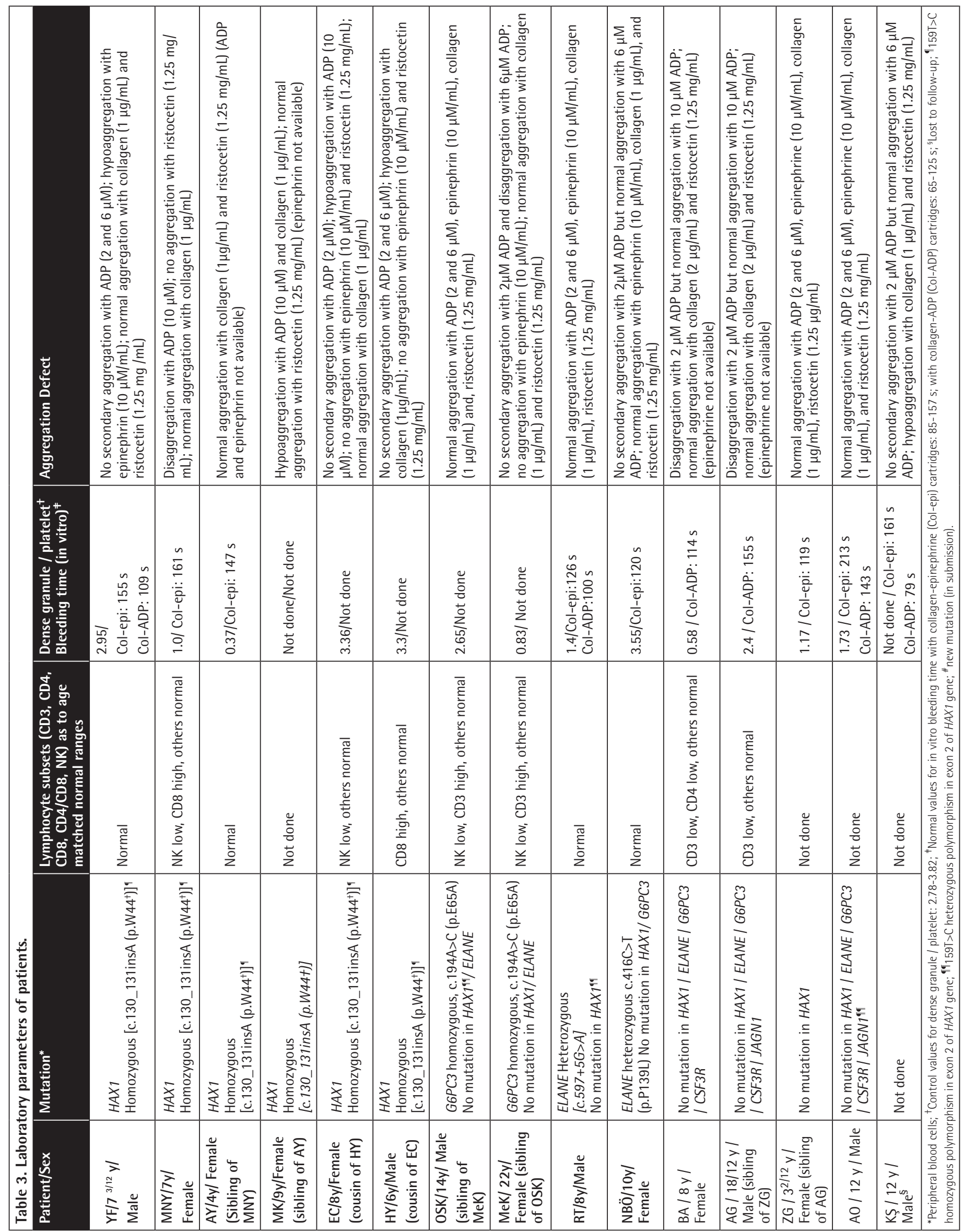




\section{Figure 2.A1}

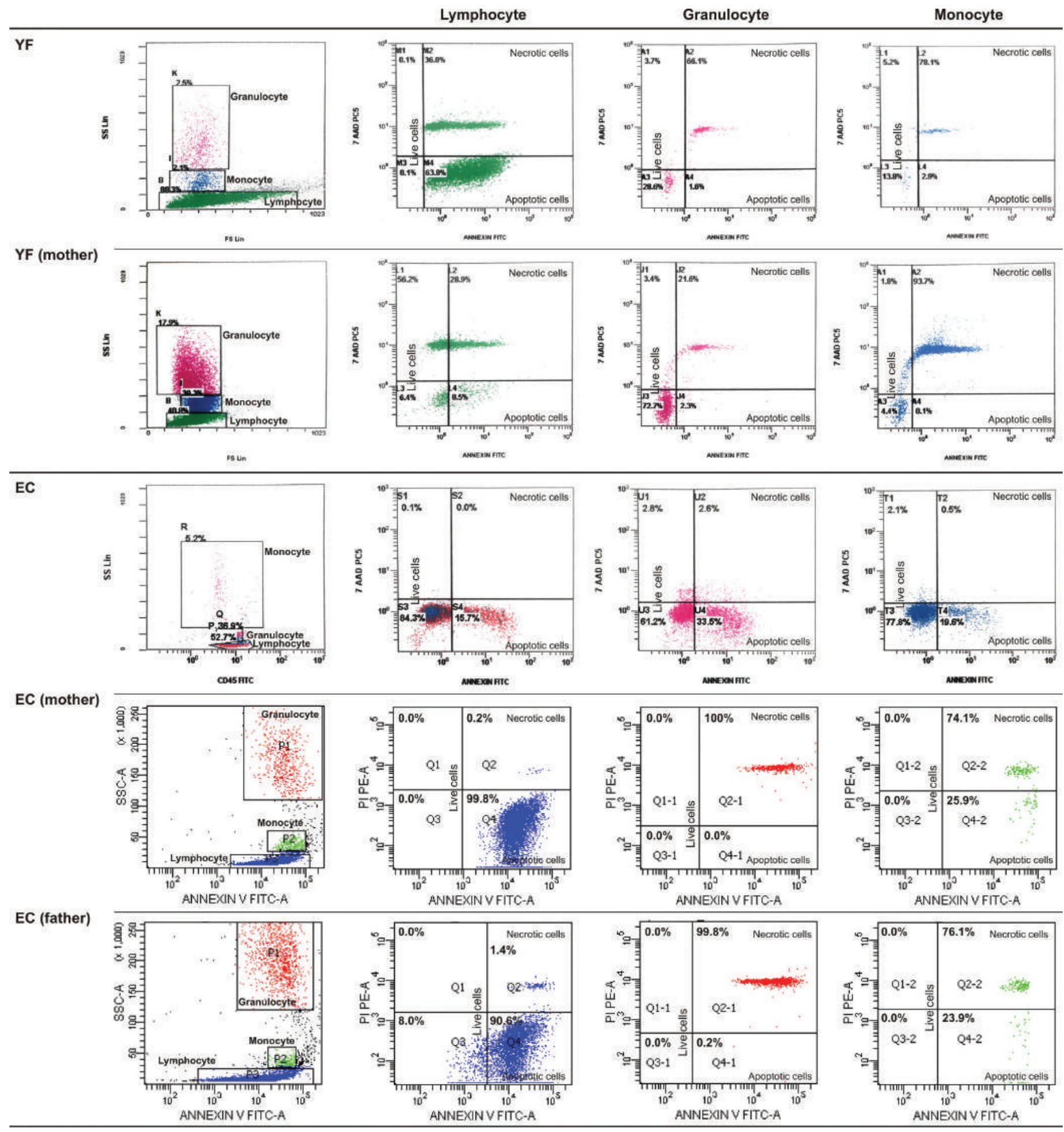

Figure 2. FACS gating and flow cytometric graphics of annexin and PI/7-AAD of lymphocytes, monocytes, and granulocytes of patients with congenital neutropenia and their parents. 2A1 and 2A2: Those of patients with HAX1 mutation (YF, EC, AY, MNY, HY) and their parents. The mother and father of AY, MY, and HY and the mother of EC were heterozygous for HAX1. 
Figure 2.A2

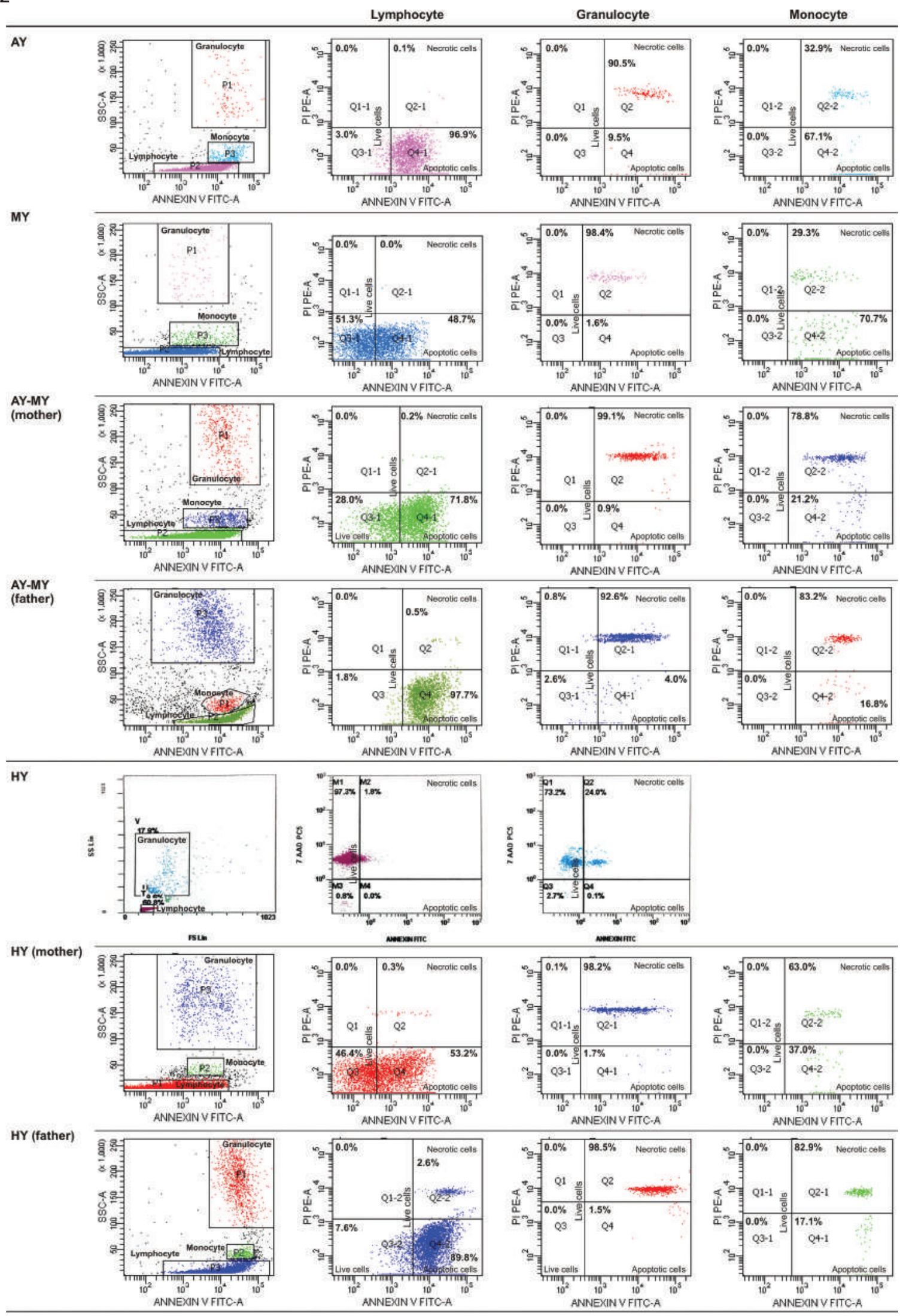

Figure 2. Continued. FACS gating and flow cytometric graphics of annexin and PI/7-AAD of lymphocytes, monocytes, and granulocytes of patients with congenital neutropenia and their parents. 2A1 and 2A2: Those of patients with HAX1 mutation (YF, EC, AY, MNY, HY) and their parents. The mother and father of AY, MY, and $\mathrm{HY}$ and the mother of EÇ were heterozygous for HAX1. 
Figure 2.B

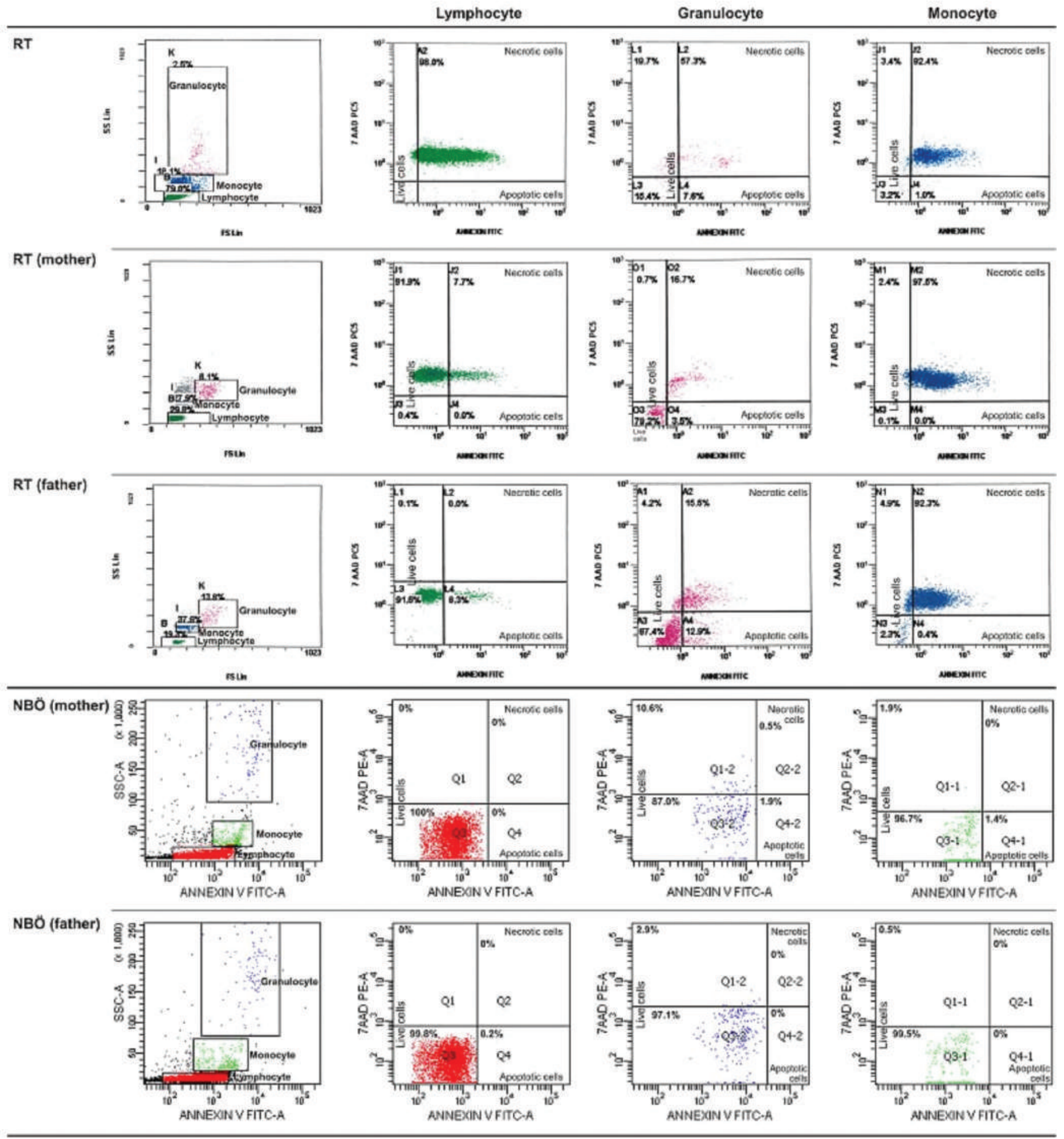

Figure 2. Continued. FACS gating and flow cytometric graphics of annexin and PI/7-AAD of lymphocytes, monocytes, and granulocytes of patients with congenital neutropenia and their parents. 2B: Those of RT with ELANE mutation and his parents and parents of NBÖ with ELANE mutation. The cells of patient NBÖ could not be evaluated. Neither of the parents had ELANE mutation in peripheral lymphocytes or buccal mucosa. 


\section{Figure 2.C}

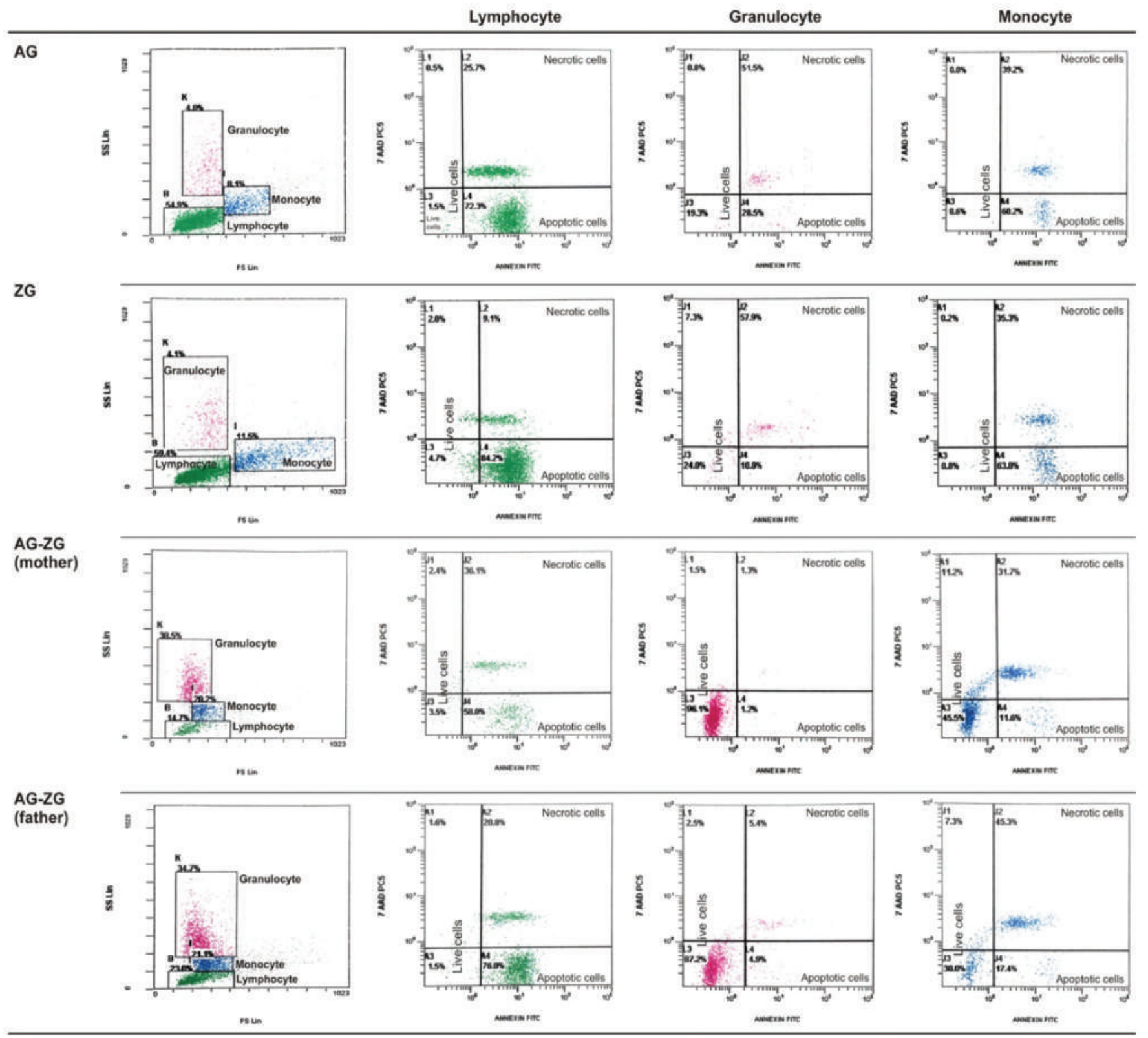

Figure 2.D
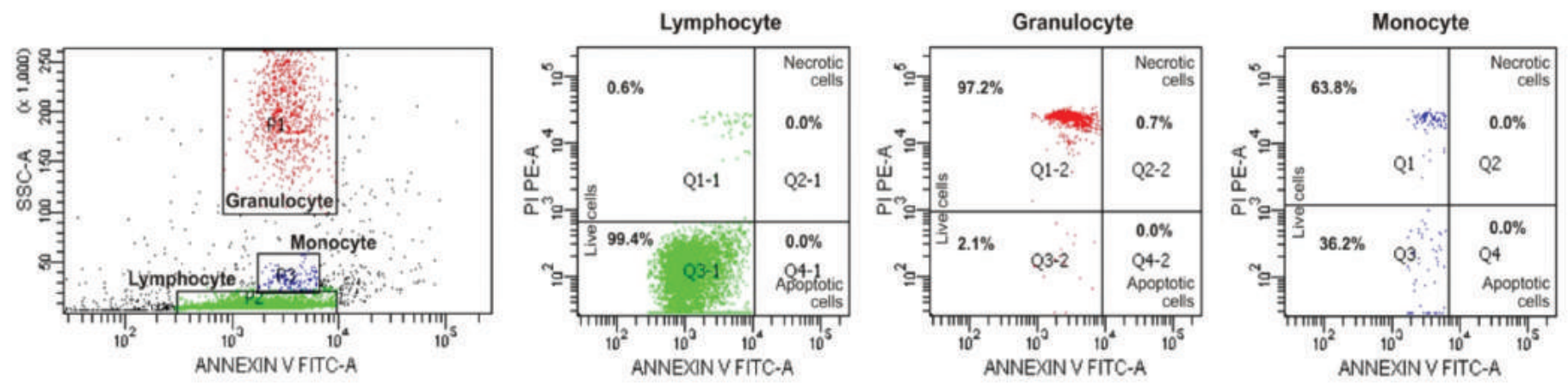

Figure 2. Continued. FACS gating and flow cytometric graphics of annexin and PI/7-AAD of lymphocytes, monocytes, and granulocytes of patients with congenital neutropenia and their parents. $2 \mathrm{C}$ : Those of two siblings with congenital neutropenia with unidentified mutation and their parents $(A G, Z G)$. 2D: Those of one of the healthy volunteers. 

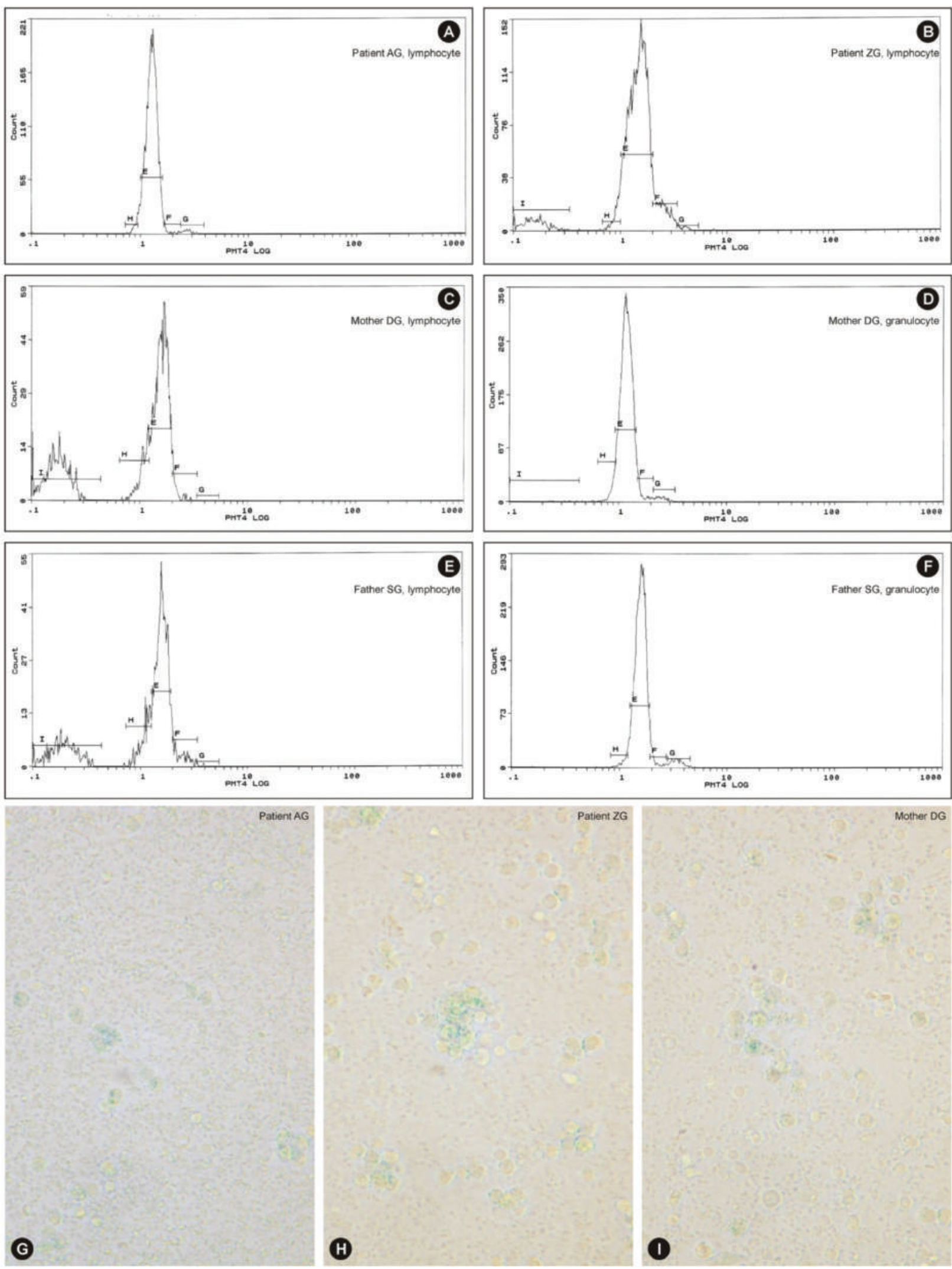

Figure 3. Cell cycle patterns of two sibling patients, their mother, and their father: A) normal cell cycle (patient AG, lymphocyte; sibling of ZG); B) G1 arrest and pre-G1 peak showing apoptosis (patient ZG; sibling of AG); C) G1 arrest and apoptosis (mother DG, lymphocyte); D) normal cell cycle (mother DG, granulocyte); E) G1 arrest and apoptosis (father SG, lymphocyte); F) normal cell cycle (father SG, granulocyte) (the patients' granulocytes could not be evaluated due to granulocytopenia). G-H-I: The leukocytes of two sibling patients and their mother stained by SA- $\beta$-gal, as blue granules, from peripheral blood culture (400×). The leukocytes of patient $A G(G)$, patient ZG $(H)$, and their mother DG (I). These patients were members of a family evaluated for cell cycles. 
erythroblasts, or apoptotic cells. Necrosis of cells that had phagocytosed other cells was also evident (Figures 6A, 6B, 6C).

\section{Megakaryopoiesis}

Megakaryocytes with asynchrony in nucleo-cytoplasmic maturation or those undergoing emperipolesis or transformed/ transforming to naked megakaryocyte nuclei were striking. Additionally, naked megakaryocyte cytoplasm just after completing thrombocyte release, many megakaryoblasts, and necrotic, apoptotic, or dysplastic megakaryocytes were also seen in the bone marrow examinations of the patients (Figures $6 \mathrm{~A}$, $6 B, 6 C)$.

\section{Thrombocytes and Thrombocyte Functions}

Thrombocytes with heterogeneous size, abnormal shape, and/or giant forms were observed on the peripheral blood smears of both the parents and patients. Giant and dysplastic thrombocytes were also evident in many patients' bone marrow under light microscope (Figures 6A, 6B, 6C).

The mean dense granule number per thrombocyte was $2.01 \pm 1.19$ (0.37-3.55) in the patients $(n=12), 2.27 \pm 1.33(0.22-4.47)$ in the parents $(n=20)$, and $3.32 \pm 0.40(2.78-3.82)$ in the healthy controls $(n=5)$, and these were comparable with each other $(p=0.147)$. However, the percentage of patients, parents, and controls who had fewer than 2 dense granules per thrombocyte was 50\%, 35\%, and 0\% respectively (Supplemental Figure 1).

Ultrastructural examination showed that the thrombocytes had a reduced number of dense granules that were heterogeneous in size, shape, and composition. The open canalicular system (OCS) was enlarged and contained unevacuated components in patients (Figures 4H, 4I, 4J, 4K, and 7A - Case 2) and parents (Figures $5 \mathrm{G}$ and $5 \mathrm{I}$ ).

In vitro bleeding time was prolonged in patients and parents by $37.5 \%$ and $18.8 \%$ with collagen-epinephrine cartridges and by $33.3 \%$ and $12.5 \%$ with collagen-ADP cartridges, respectively, vs. $0 \%$ in the control group with both cartridges. While in vitro bleeding times in patients and parents were comparable $(p=0.293$ and 0.233 , respectively), only the in vitro bleeding time with collagen-ADP in patients was longer than in the control $(p=0.031)$ (Supplemental Table 4).

Up to $63.6 \%$ and $44.4 \%$ of the aggregation results performed with various reactive substances in patients and their family members displayed abnormalities (Table 3; Supplemental Tables 5 and 6).

Thrombocyte aggregation at the $2^{\text {nd }}, 8^{\text {th }}$, and $14^{\text {th }}$ minutes under TEM (Figure 7) revealed a lack of adhesion and a lack of or inadequate secretion as also seen in Figures 4H, 4I, 4J, 4K, 5G, and $5 \mathrm{I}$, with delayed or defective centralization, development of pseudopods, and/or secretion, abnormal degranulation, dissociation phenomenon [23,24], and abnormal amoeboid cytoplasmic protrusions (Supplemental Results).

There was inconsistency between the presence of hemorrhagic diathesis and abnormality of laboratory tests (aggregation tests, dense granule number in thrombocytes, in vitro bleeding time, thrombocyte ultrastructure) and vice versa. Not all these abnormalities coexisted all together (Table 3; Supplemental Table 6).

\section{Genetic Mutations}

Fourteen of 15 patients and 9 of 21 parents were evaluated for genetic mutations. Patients had homozygous [c.130_131insA (p.W44*)] mutation in the second exon of the HAX1 gene $(n=6)$, heterozygous ELANE mutations [c.597+5G>A and c.416C $>T$ (p.P139L) $(n=2)]$, and homozygous G6PC3 mutation [c.194A>C (p.E65A), $n=2$ ], which is a novel mutation in the literature and is predicted to be disease-causing by SIFT and MutationTaster in silico analysis software [in submission]. Five had unidentified mutations. No tested patient had CSF3R mutation. ELANE c.597+5G $>$ A splicing mutation was predicted to be diseasecausing by NNSPLICE, GeneSplicer, and Human Splicing Finder in silico prediction tools.

Patients with $H A X 1$ displayed coexistent homozygous c.159T>C polymorphism in the second exon of the HAX1 gene. Three patients with other mutations were heterozygous for this polymorphism (Tables 1 and 3). Both the mother and father of $A Y, M N Y$, and $H Y$ and the mother of $E C$ were found heterozygous for HAX1 [c.130_131insA (p.W44*)]. The parents of the two patients with heterozygous ELANE mutation revealed no mutation in the ELANE gene and their buccal mucosa cells did not reveal mosaicism.

\section{Discussion}

In this study, we showed that non-granulocytic blood cells were also affected and that morphologic and functional changes occurred in patients with SCN and in their non-neutropenic family members, and cell death mechanisms other than apoptosis also operated.

\section{Apoptosis and Secondary Necrosis in Granulocytic and Non- Granulocytic Cells}

It has been reported that in SCN and other neutropenic states, accelerated apoptosis of bone marrow granulocytic progenitor cells $[1,2,6,25,26,27,28,29,30,31]$ and lymphocyte apoptosis $[7,8]$ took place through different mechanisms. In our study, apoptosis was demonstrated not only in granulocytes and lymphocytes but also in monocytes by elevated annexin $\mathrm{V}$, ultrastructural appearance, and a pre-G1 peak in cell cycle analysis. The absence of a pre-G1 peak is not enough to exclude 

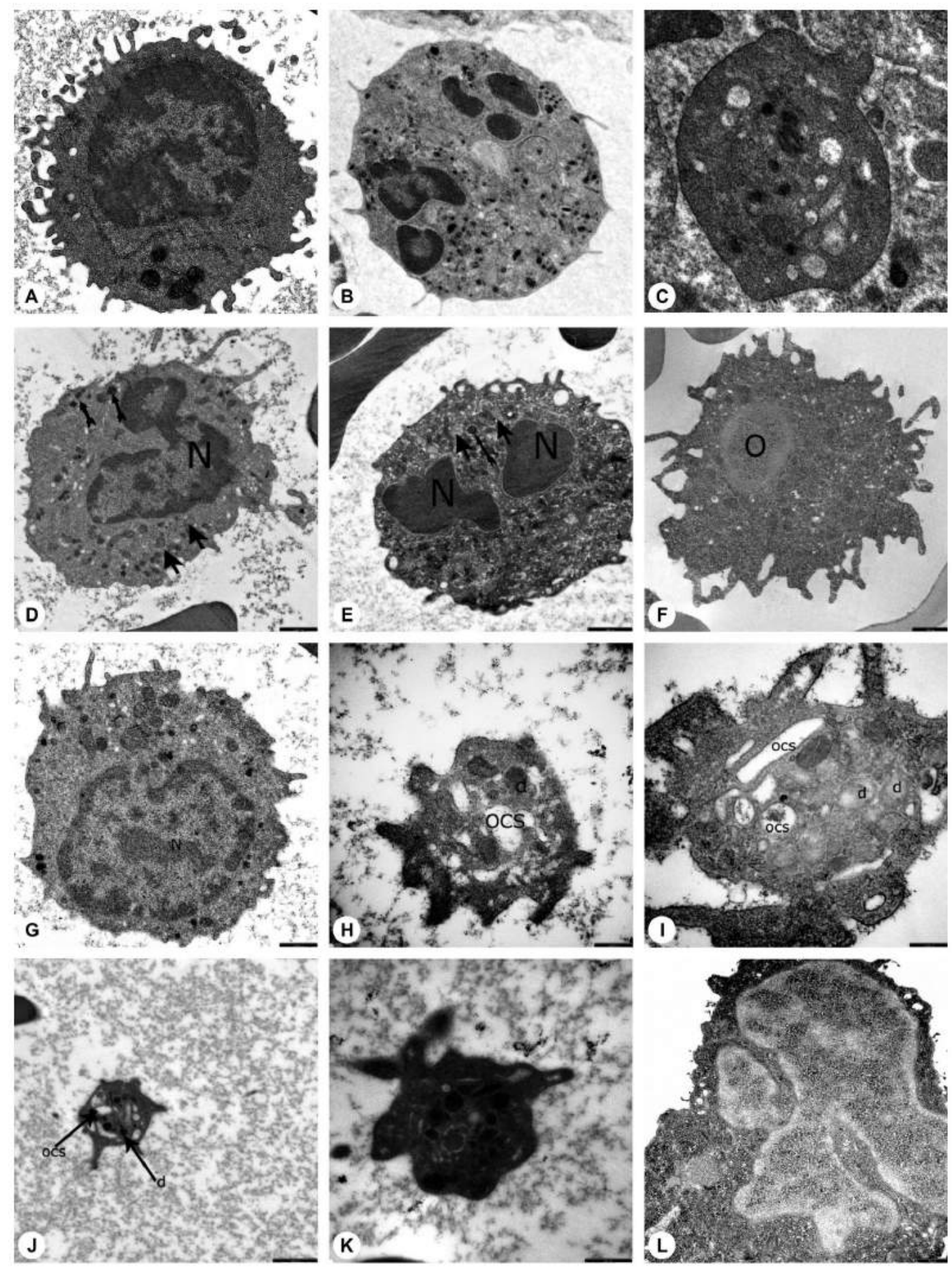

Figure 4. Electron microscopic images of the blood cells of the patients. A) Normal lymphocyte $\left.\left(16700^{x}\right), B\right)$ normal neutrophil $\left(3597^{x}\right)$, C) normal thrombocyte $\left(10000^{\times}\right)$, D) patient EC (with HAX1 mutation) $\left(12930^{\star}\right)$, E) patient NBO (with ELANE mutation) (12930x), F) patient OSK (with G6PC3 mutation) (10000x), G) patient EC (with HAX1 mutation) (16700), H) patient EC (with HAX1 mutation) (35970), I) patient MeK (with G6PC3 mutation) (46460x), J) patient MNY (with HAX1 mutation) (12930x), K) patient NBÖ (with ELANE mutation) $\left(27800^{\times}\right)$, L) patient MeK (with G6PC3 mutation) (14000) (N: nucleus; thick arrow: primary granule; thin arrow: secondary granule; OCS: open canalicular system; d: dense granule; *: segment of non-apoptotic nucleus; arrow head: fusion of granules; 0: autophagosome). Decreased number of secondary granules in the neutrophils (Figures 4D, 4E), which were abnormal in shape (4L). Primary granules that were irregular in shape (Figures 4E, 4L) or large (Figure 4D) and had a tendency to combine and condense (Figure 4E). Chromatin clumping in nuclei (Figure 4D) and apoptosis (Figure 4E). An active lymphocyte (Figure 4G). Abnormal giant mononuclear cell with abundant mitochondria and autophagic vacuole (Figure 4F). Dense granules in platelets, which were large and giant (Figure 4H), reduced in number (Figure $4 \mathrm{H}$ ), in different shapes and dimensions (Figures $4 \mathrm{H}, 4 \mathrm{~J}, 4 \mathrm{~K}$ ) with varying components (Figure 4l). Enlarged open canalicular system due to unevacuated ingredients (Figures $4 \mathrm{H}, 4 \mathrm{I}, 4 \mathrm{~J}, 4 \mathrm{~K}$ ). 

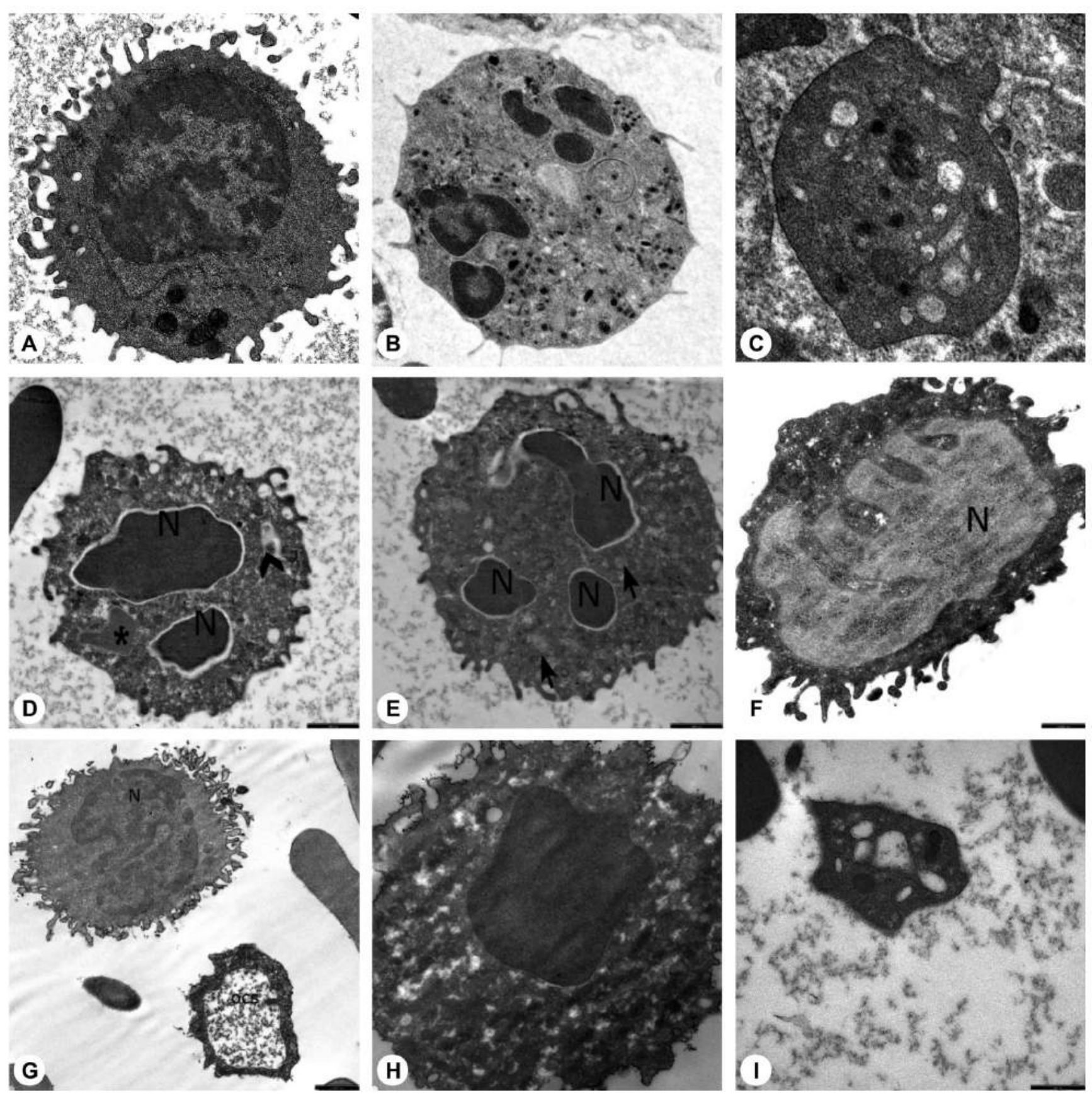

Figure 5. Electron microscopic images of the blood cells of the parents. A) Normal lymphocyte $\left.\left(16700^{x}\right), B\right)$ normal neutrophil $\left(3597^{x}\right)$, C) normal thrombocyte $\left.\left(10000^{\star}\right), \mathrm{D}\right)$ mother of AO (with unidentified mutation) (SO) $\left(12930^{x}\right)$, E) mother of AO (with unidentified mutation) (S0) $\left(12930^{x}\right)$, F) father of MeK and OSK (with G6PC3 mutation) (MK) $\left(16700^{\times}\right), G$ ) father of MeK and OSK (with G6PC3 mutation) (MK) $\left.\left(10000^{\times}\right), \mathrm{H}\right)$ father of MeK and OSK (with G6PC3 mutation) (MK) (21560), I) father of MNY and AY (with HAX1 mutation) (AhY) (27000) ( $N$ : nucleus; thick arrow: primary granule; thin arrow: secondary granule; OCS: open canalicular system; d: dense granule; * : segment of non-apoptotic nucleus; arrow head: fusion of granules; 0 : autophagosome). Decreased number of secondary granules in the neutrophils (Figures 5D, 5E). Primary granules in irregular shape (Figure 5D). Chromatin clumping in nuclei (Figure 5D) and apoptosis (Figures 5D, 5E, $5 \mathrm{H}$ ). Abnormal lymphocytes (Figures 5F, 5G). Dense granules in platelets, which were large and giant (Figure 5I). Open canalicular system enlarged due to unevacuated ingredients (Figures $5 \mathrm{G}, 5 \mathrm{H}, 5 \mathrm{I}$ ). 
Figure 6.A

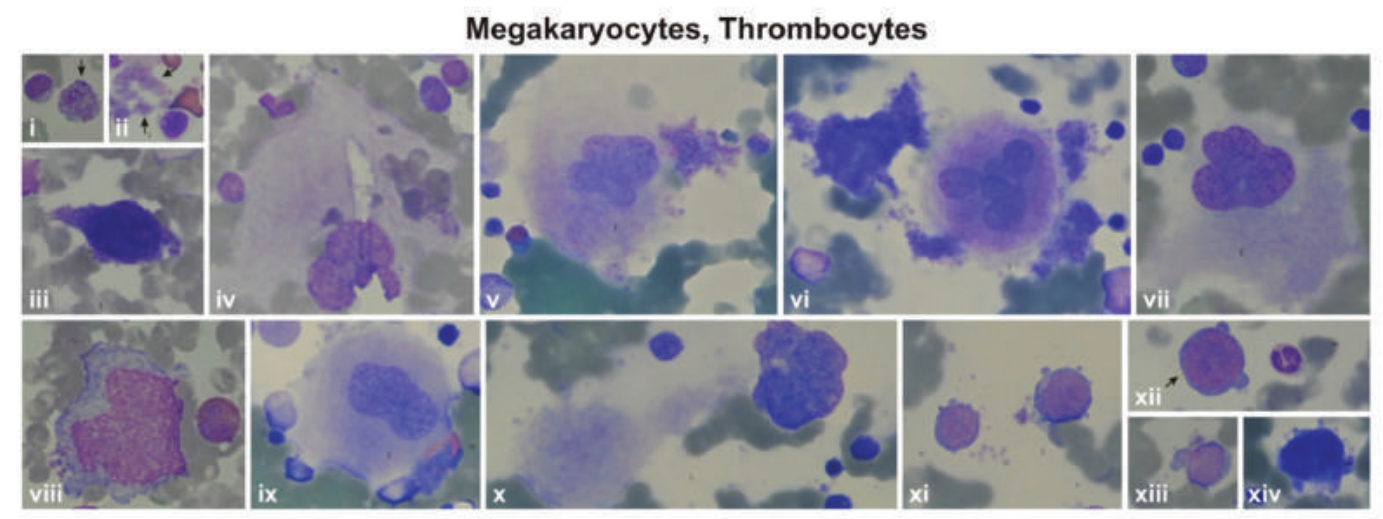

Monocytes, Macrophages, Histiocytes
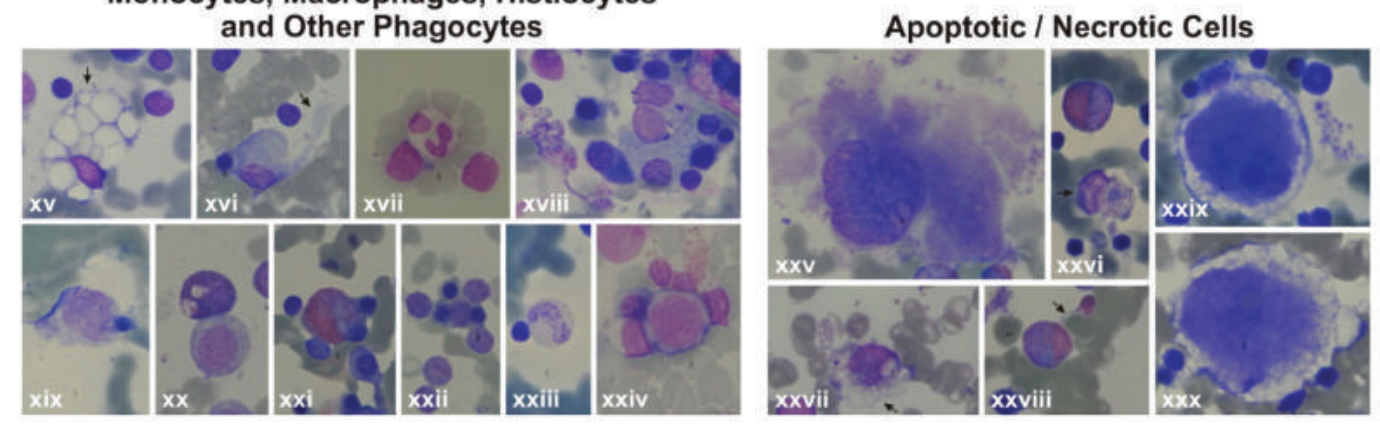

Figure 6.B

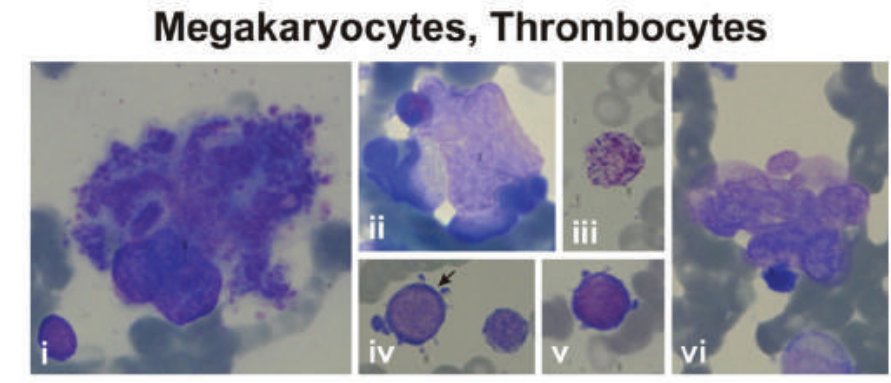

Monocytes, Macrophages, Histiocytes and Other Phagocytes

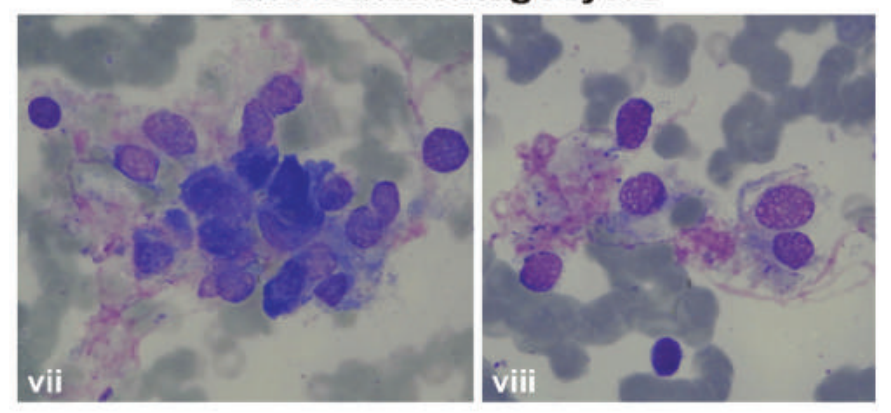

Apoptotic / Necrotic Cells

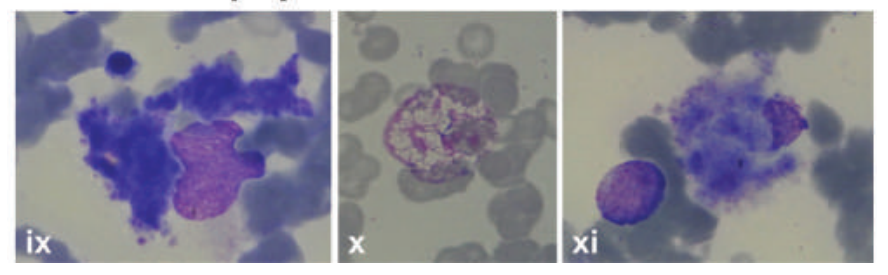


Figure 6.C

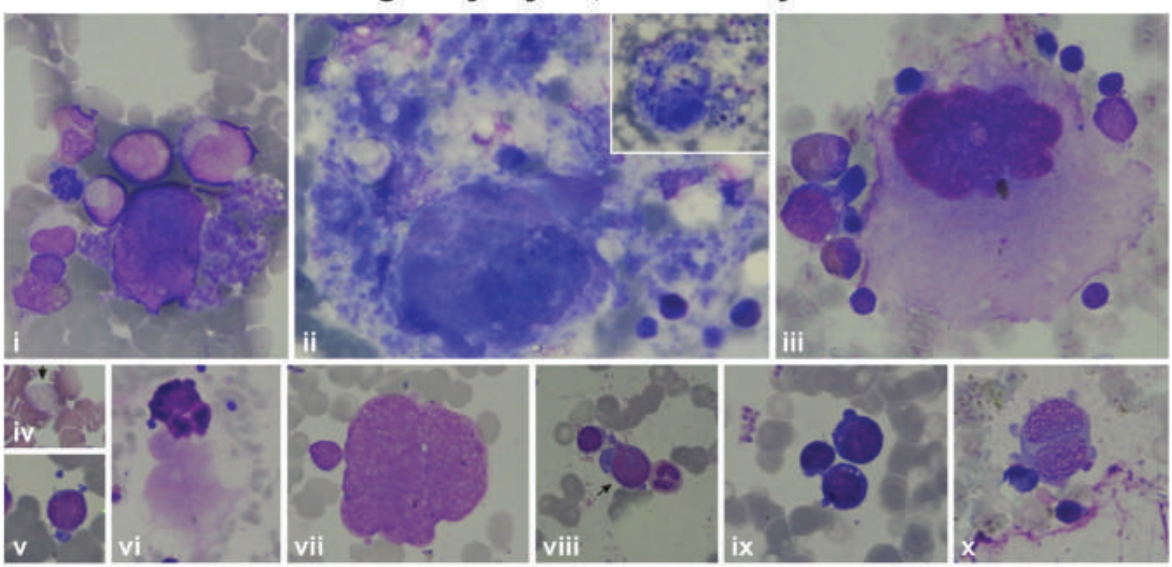

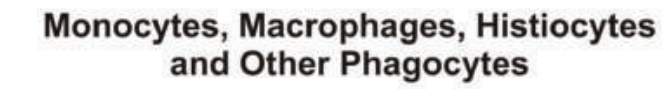
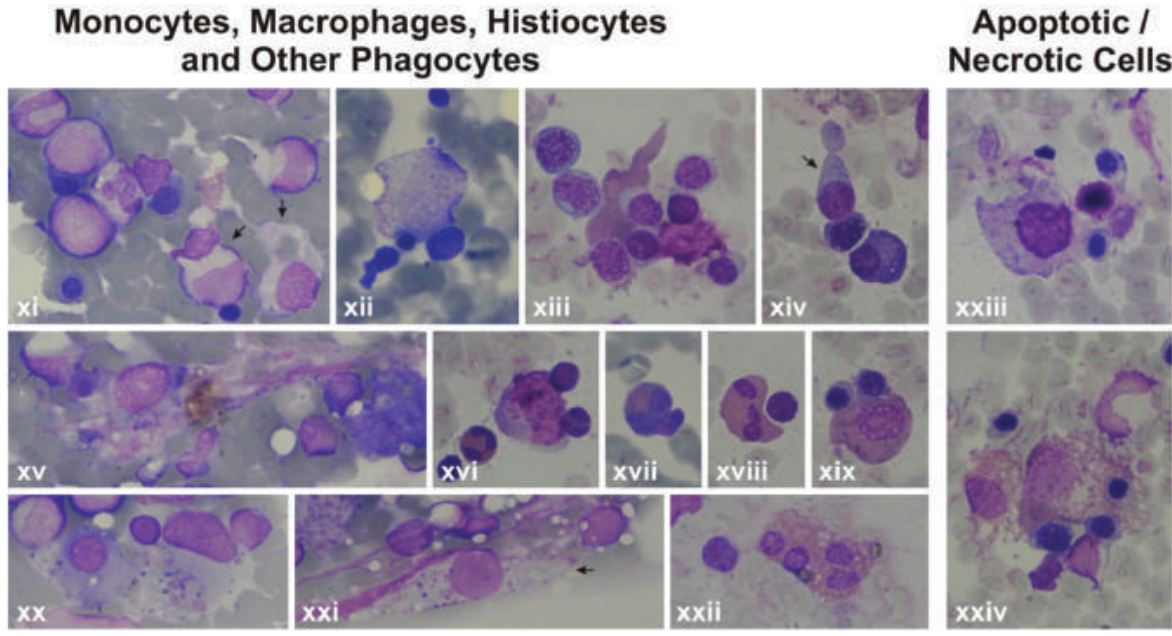
Necrotic Cells

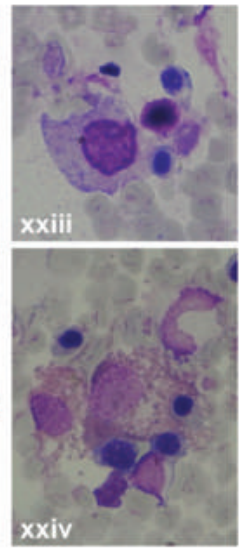

Figure 6. Features of some bone marrow cells (megakaryocytes, thrombocytes, monocytes, macrophages, histiocytes, other phagocytes, and apoptotic/necrotic cells) of the patients by light microscope. 6A: Features of some bone marrow cells from the patients with $H A X 1$ mutation. i, xxvii, xxviii): Patient AY; ii) Patient EÇ; iii, iv, viii, xvi, xxx) Patient MNY; v, vi, x, xii, xv, xvii, xviii, xxi, xxii, xxiii, xxiv, xxvi) Patient MK; vii, xiv, xxix) Patient YF; xi, xii, xiii, xix, xx, xxv) Patient HY (1000). i) Giant thrombocyte; ii) dysplastic thrombocytes; iii, xi, xii, xiii, xiv) Megakaryoblasts with nucleo-cytoplasmic asynchrony; iv, $v, v i, i x)$ senescent megakaryocytes undergoing the process of being naked megakaryocyte nucleus and naked megakaryocyte cytoplasm, just as producing $(v$, vi) or after completing production of thrombocytes (iv, vii, ix), with emperipolesis of other bone marrow cells (iv, ix); viii) Abnormal megakaryocyte; $x$ ) a megakaryocyte that has just developed into a naked megakaryocyte nucleus and naked megakaryocyte cytoplasm. xv) A macrophage full of fat (Gaucher-like cell); xvi, xix, xxii, xxiv) monocytes that are phagocytosing various mononuclear cells; $x \mathrm{x}$ ) a monocyte phagocytosing an apoptotic cell; xvii, xxi, xxiii) other phagocytes like a neutrophil (xvii), eosinophilic myelocyte (xxi), and stab (xxiii) that are phagocytosing other bone marrow cells; xxv) A megakaryocyte undergoing necrosis; xxix, xxx) megakaryocytes undergoing apoptosis; xxvi) a monocyte that had performed phagocytosis and is undergoing necrosis; xxvii) a monocyte undergoing necrosis; xxviii) an eosinophilic myelocyte with an apoptotic body attached to the cell. 6B: Features of some bone marrow cells from the patients with ELANE mutation. $\mathrm{i}$, iii, iv, vii, viii, ix, $\mathrm{x}$, xi) Patient NBÖ (1000×); ii, iv, vi) Patient RT (1000). i) A degenerating dysplastic megakaryocyte; ii) a mononuclear megakaryocyte undergoing emperipolesis; iii) a giant thrombocyte; iv, v) megakaryoblasts with nucleocytoplasmic asynchrony; vi) naked megakaryocyte nuclei that could not transform to unique nuclei. vii, viii) Histiocytes that phagocytosed many bone marrow cells; ix) A megakaryocyte that is just about to undergo necrosis; $\mathrm{x}$ ) a ghost-like cell degenerating through secondary necrosis; xi) a necrotic megakaryocyte. $6 \mathrm{C}$ : Features of some bone marrow cells from the patients with unidentified mutations. $i, v, v i i, v i i i, x i, x v, x x$, xxi) Patient AO; iii, vi, ix, x, xiii, xiv, xvi, xviii, xix, xxii, xxiii, xxiv) Patient ZG; iv) Patient BA; ii, xii, xvii) Patient KŞ (1000, except Figure vi, which is presented at $\left.400^{\times}\right)$. i) A megakaryocyte with nucleo-cytoplasmic asynchrony; ii, iii) senescent megakaryocytes undergoing the process of transformation to naked megakaryocyte nucleus and naked megakaryocyte cytoplasm, just as producing thrombocytes (ii) or after finishing production of thrombocytes (iii) or with emperipolesis (iii); iv) a giant thrombocyte; $v_{1}$ viii, ix) megakaryoblasts; vii) a megakaryocyte that is just transforming to naked megakaryocyte nucleus and naked megakaryocyte cytoplasm; vii) a naked megakaryocyte nucleus; $\mathrm{x}$ ) a dysplastic megakaryocyte with two nuclei and scanty cytoplasm but thrombocyte production; xi, xii, xvi, xix) Monocytes (xi, xiv), macrophages (xii, xvi, xix) that had phagocytosed or are phagocytosing bone marrow cells with eosinophilic cytoplasm (xix) or pseudopods (xiv); $x v_{1} x x_{1} x \mathrm{xi}$ ) histiocytes that have been phagocytizing bone marrow cells $(x v, x x)$ and/or consist of basophilic debris, which gives the appearance of sea blue-like histiocytes ( $\left.\left.x v_{1} x x, x x i\right) ; x v i i, x v i i i\right)$ phagocytosis of other phagocytes like eosinophils (xviii) or eosinophil metamyelocytes (xvii); xxiii, xxiv) Macrophages with normal (xxiii) or eosinophilic (xxiv) cytoplasm that had performed hemophagocytosis and are undergoing necrosis now. 

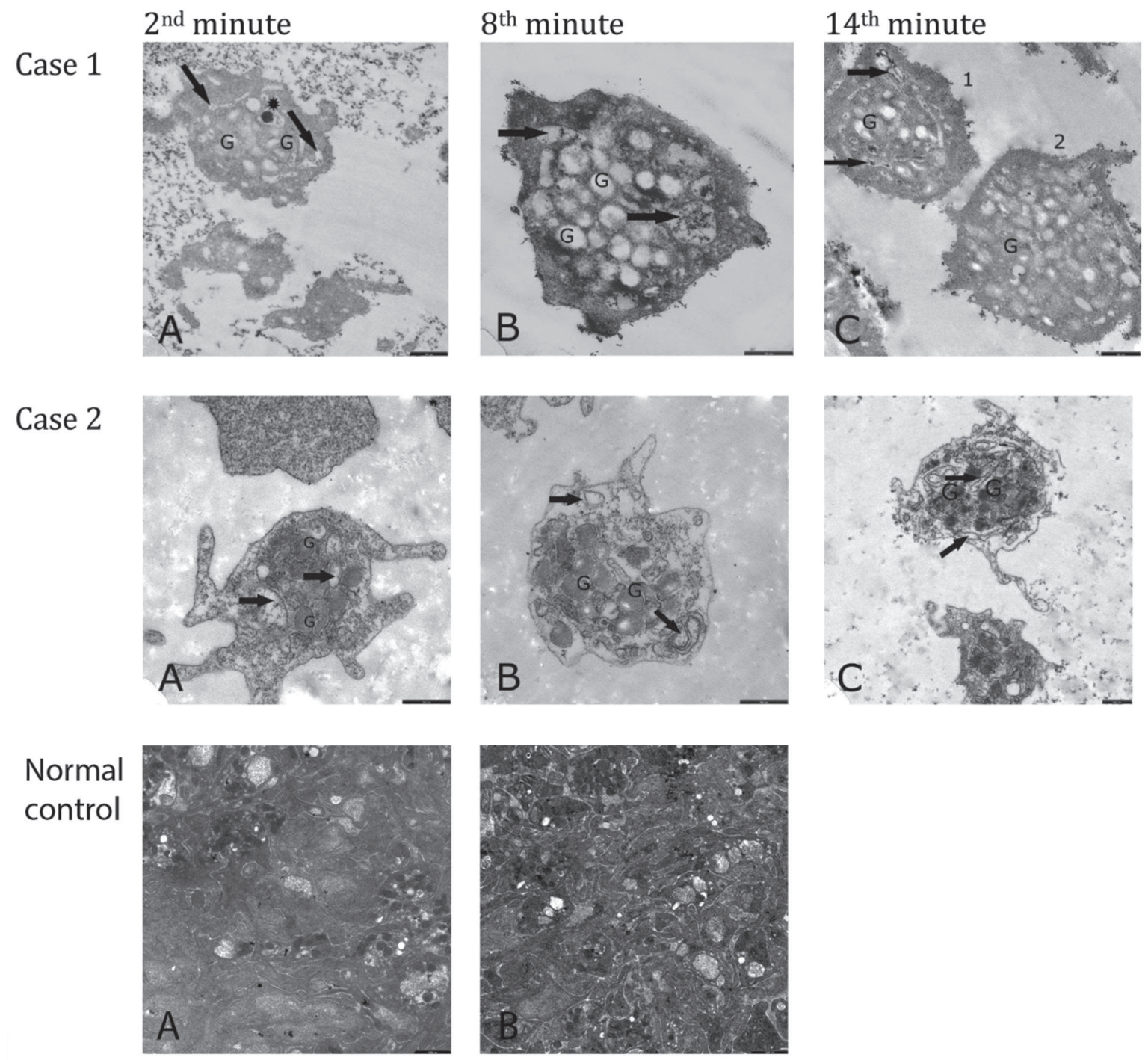

Figure 7. Electron microscopic images of the aggregating thrombocytes after addition of $2 \mu \mathrm{M}$ ADP. All bars are $500 \mathrm{~nm}$. Case 1 (patient BA, with unidentified mutation): A) $2^{\text {nd }}$ minute of aggregation: Thrombocytes are seen to have become close to each other; the granules $(\mathrm{G})$ have centralized; open canalicular system is enlarged $(\uparrow)$; one dense granule is visible in enlarged open canalicular system $(*)$. B) $8^{\text {th }}$ minute of aggregation: Platelets are still distant from each other. There are no platelets that fit tightly to each other. However, the granules $(\mathrm{G})$ have centralized and have discharged their ingredients. Open canalicular system is enlarged and consists of residual secretion ( $\uparrow$ ). There are a few granules that have not evacuated their ingredients yet. C) $14^{\text {th }}$ minute of aggregation: The platelets are seen to have become closer but they are still apart from each other. The open canalicular system is enlarged and consists of some secretion $(\uparrow)$. There are and there are not undischarged granules $(\mathrm{G})$ in thrombocytes 1 and 2, respectively. Case 2 (Patient ZG, with unidentified mutation): A) $2^{\text {nd }}$ minute of aggregation: Thrombocytes are seen to be apart from each other; the granules (G) have fairly centralized and are intact. B) $8^{\text {th }}$ minute of aggregation: The granules $(G)$ are larger than normal and increased in number. They have centralized but have not discharged their contents yet. Pseudopods have developed. The open canalicular system has not enlarged yet ( $\uparrow$ ). C) $14^{\text {th }}$ minute of aggregation: The thrombocytes have not adhered to each other yet. The dense granules are distributed throughout the cytoplasm but the majority have not discharged their contents yet. Upper thrombocyte: The granules $(\mathrm{G})$ are very large and increased in number. None of them have evacuated their contents. Open canalicular system ( $\uparrow$ ) is apparent. Normal Control: A) $2^{\text {nd }}$ minute of aggregation: Thrombocytes are seen to fit tightly together and display abundant pseudopods. They have released almost all of their granules. B) $8^{\text {th }}$ minute of aggregation: Thrombocytes fit tightly together. They have degranulated completely, except a few. 
apoptosis [32]. Inconsistent elevations in CD95 and CD95 ligand pointed at a non-CD95-mediated apoptosis.

Only in the case of excessive apoptosis, during which the capacity of phagocytes to engulf apoptotic cells is reduced, do the uncleared apoptotic cells and fragments undergo secondary necrosis (delayed apoptotic clearance), which can provoke inflammation [33]. Our flow cytometric and microscopic findings revealed that apoptotic and necrotic cells coexisted in three cell lines in patients irrespective of the type of SCN mutation, and in their parents.

We think that in our patients apoptotic and necrotic cells in the myeloid lineage activated macrophages and other phagocytes extensively (Figures 6A,6B,6C), inducing secretion of TNFalpha, IL-1, IL-6, and IL-12 by activated macrophages, the latter exacerbating macrophage activation through stimulating IFNgamma production $[34,35]$. High levels of TNF-alpha $[36,37]$ in SCN patients and their non-neutropenic parents [36] and increased capacity of stimulated monocytes to produce TNFalpha on stimulation through certain toll-like receptors $[38,39]$ were reported before.

We consider the apoptosis in the non-granulocytic cells to be due to the high TNF-alpha levels, which can give rise to apoptosis in neutrophils $[40,41]$, lymphocytes $[42,43]$, monocytes [44], and thrombocytes [45] in various conditions [46] through TNF alpha-TNFR1 interaction (Supplemental Discussion, Text 1).

\section{Cytopenia in Non-Granulocytic Cells and RCS}

Absence of lymphopenia (except 1 case), monocytopenia, and thrombocytopenia (Table 1; Supplemental Table 2) is apparently due to good compensation of the bone marrow of both the patients and the parents.

However, it was striking that both patients and their parents had quantitative abnormalities in T lymphocytes and NK cells, regardless of the type of the SCN mutation carried by the patients.

Abnormalities in B, cytotoxic $\mathrm{T}, \mathrm{NK}, \mathrm{NKT}$, Th2, and Th7 cells were reported in SCN with GFI-1 mutation, albinismneutropenia syndromes, and Wiskott-Aldrich syndrome (WAS) $[2,47,48,49,50,51]$. None of our cases were clinically compatible with WAS or albinism-neutropenia syndromes. However, 2 SCN patients with WAS mutation were reported to have a reduced number of NK and CD4+ cells [7]. Interestingly, SCN patients with ELANE and unidentified mutations were reported to have normal numbers of NK cells that were less mature than those of normal controls [52]. NK cell deficiency and dysfunction was reported in some chronic neutropenia patients with morphological abnormalities [53]. In our cases, patients with NK levels lower than the normal range for age had HAX1 $(\mathrm{n}=2)$ and G6PC3 $(\mathrm{n}=2)$ mutations while patients with low CD3 $(n=2)$ and CD4 $(n=1)$ levels had unidentified mutations (Table 3). Mature neutrophils are reportedly necessary for NK cell development [52]. Reduced mature neutrophils may account for low levels of NK cells in the patient group but the reasons why not all SCN patients had low NK cells and why the parents who had low NK levels were not neutropenic require further investigations.

That the patients with low $\mathrm{CD} 3+$ and $\mathrm{CD} 4+$ lymphocytes $(\mathrm{AG}$, ZG) were those with $\beta$-gal positivity of leukocytes suggests that the continual presence of circulating pro-inflammatory factors secreted by activated macrophages kept the immune system in a state of chronic low-level activation, giving rise to immunosenescence through loss of telomeric DNA with each S phase and therefore a decline in the number of T lymphocytes and no change or decline in overall lymphocyte and NK cells [54] during which inflammatory mediators secreted by senescent cells themselves contributed to immunosenescence $[55,56]$ (we could not evaluate B lymphocytes) (Supplemental Discussion, Text 2).

The presence of apoptosis together with RCS was reported in SCN [8] and in cell lines that had been administered cytotoxic drugs [57]. These cases (ZG and parents) in which individuals had not consumed cytotoxic drugs and were exposed to radiation may carry an unknown DNA-disrupting factor.

Cellular senescence is the state of irreversible cell cycle arrest, predominantly in the $\mathrm{G} 1$ phase $[57,58,59,60,61,62,63,64]$, being dependent on (replicative senescence) or independent of telomeres (RCS) $[60,61]$. The latter is due to inappropriately expressed pro-proliferative genes [63], oncogenic mutations [62], DNA-damaging drugs, or gamma irradiation $[57,58]$.

The senescence-like phenotype is characterized by reorganization of heterochromatin $[65,66]$, formation of fragmented nuclei, polyploidy, and enlarged and flattened cell shape, along with expression of SA- $\beta$-gal positivity $[15,57]$ and alterations in the cell cycle [65].

\section{Dysplasia of Hematopoietic Cells}

In our study, as reported previously $[8,10]$, dysplasia was noted not only in the neutrophil series but also in the monocyte, megakaryocyte, lymphocyte, and eosinophil series in all patients and parents to various degrees. Some dysplasia parameters overlap with the senescence phenotype; however, restriction of RCS to a few cases in our study showed that RCS only partially affected the development of dysplasia. Our previous studies point at the role of inflammatory cytokines to cause dysplasia $[36,37]$ in patients with autoimmune disorders, acute infections, and hemophagocytic histiocytosis $[67,56]$. The pro-inflammatory cytokines secreted by activated 
macrophages can destroy the bone marrow microenvironment and hematopoietic stem cell niches by activating innate immune cells [55] and give rise to hematopoietic stem cell dysfunction, dyshematopoiesis, and thus dysplastic hematopoietic cells.

Morphologic abnormalities due to abnormal differentiation in myeloid cells are also encountered in congenital, cyclic, dysgranulopoietic neutropenia cases $[7,10,66,68]$ with or without the WAS, GFI-1, and G6PC3 mutations $[1,7]$, in myelodysplastic syndrome, and in a number of non-malignant disorders $[16,67]$.

\section{Dysmegakaryopoiesis and Hemorrhagic Diathesis}

That the presence of nearly no normal megakaryocytes in our patients and that nearly all megakaryocytes displayed characteristics of naked megakaryocyte nuclei, emperipolesis, or abnormal morphology like peripheral vacuolization (showing non-classical apoptosis: para-apoptosis) and directly destructed megakaryocytes (showing necrosis) and presence of many stage 1 megakaryocytes (megakaryoblasts), some of which were aberrantly releasing thrombocytes, imply defective megakaryocyte maturation, heavy intramedullary premature cell death of megakaryocytes, and increased megakaryopoiesis $\quad[14,69,70,71,72,73] \quad$ (Supplemental Discussion, Text 3).

Defective maturation in megakaryocytes is also expected to be due to the increased levels of pro-inflammatory cytokines, which can destroy the bone marrow microenvironment and hematopoietic stem cell niches [55]. Therefore, thrombocytes derived from megakaryocytes with defective maturation are also expected to be functionally abnormal.

Hence, in our cases, we noted a combination of thrombocyte functional defects and in a few of them a low number of mepacrine-labeled dense granules reminiscent of a delta storage pool defect. The ultrastructural view of aggregating thrombocytes (Figure 7; Supplemental Discussion, Text 3) may reflect defective transmission. From all these aspects, the findings of our patients resemble the thrombocyte disorders encountered in leukemia, refractory anemia, cystinosis, and others $[19,23,24,74,75]$.

Hemorrhagic diathesis is a common finding of albinismneutropenia syndromes like Chediak-Higashi syndrome, Hermansky-Pudlak syndrome type 2, Griselli's syndrome type 2, Cohen's syndrome, and p14 deficiency [51] but has not been reported in SCN [76] before.

Our results, at the same time, confirmed that not all patients with thrombocyte aggregation defects display laboratory evidence $[18,77,78]$ and the most reliable tool to show thrombocyte aggregation defect is electron microscopic evaluation $[78,79,80]$.

\section{Parents}

No parent had cytopenia; however, apoptosis and secondary necrosis to various degrees in granulocytes, monocytes, and lymphocytes with the presence of dysplasia, decreased NK cells, and abnormalities in thrombocyte functions in most of the parents and RCS in one suggest that the parents were also affected by the same genetic abnormality but the cell loss was well compensated by the proliferating compartment. However, only the parents of patients with ELANE and those of most patients with $H A X 1$ could be evaluated genetically.

For the parents of the patients with homozygous HAX1 mutation (AY, MNY, HY, EÇ) who were heterozygous for the same mutation, we think that cell loss took place through one mutant allele, just like in their children. The apoptotic hematopoietic cells (lymphocytes, neutrophils, monocytes) were the mutant cells that were lost early $[81,82]$, but normal hematopoiesis compensated for the cell loss when the other allele was normal.

As for the parents of patients with ELANE mutation (RT, NBÖ), the absence of ELANE mutation in the parents' peripheral blood cells led us to consider that the parents were either mosaic for the mutation or actually normal and their children were sporadic cases of ELANE mutation. Hence, a number of phenotypically healthy parents were shown to harbor somatic [83], only germline [3], or both somatic and germline [84] mosaicism of ELANE mutation. On the other hand, most of the sporadic cases of SCN were reported to have ELANE mutations [85].

That we could not detect mosaicism in the buccal mucosa cells of the parents does not rule out mosaicism definitively. A search for mutant alleles in various other cell types like skin or sperm of the father, preferably using more sensitive mutation analysis methods, might have proved mosaicism, like in the reported cases $[3,86]$ in which the mutant allele was negative in DNA from neutrophils, buccal mucosa, and/or lymphocytes and was detected only in spermatozoa. However, the parents felt uneasy about being tested any further.

Additionally, that the parents of patient RT had normal blood cell counts but high cell death parameters in lymphocytes, granulocytes, and monocytes like the parents with heterozygous $H A X 1$ suggested that they were very probably affected by the same mutation in the same gene, ELANE, as their children. However, we cannot exclude the possibility that patient RT was a sporadic case of ELANE mutation and did not additionally harbor any other untested/unidentified neutropenia mutation [87] and that his parents were carriers of this mutation. On the other hand, similar death parameters in the hematopoietic cells of the parents of NBÖ to those of the controls suggested that the ELANE mutation in NBÖ could be sporadic. As a second possibility, both of the parents of NBÖ might have cyclic hematopoiesis with consecutive normal and abnormal 
hematopoiesis [88], just like in the mother of a patient with JAGN1 mutation who we followed before $[8,10$, unpublished data]. However, we could not exclude an unidentified mosaicism for the parents of NBÖ definitively due to the same reasons.

As for the parents of patients with G6PC3 (OSK, MeK) and unidentified mutations ( $A O, B A, A G, Z G, K S$ ), only two siblings with unidentified mutation $(A G, Z G)$ and their parents could be evaluated for cell death parameters and both the parents' blood cells (lymphocytes, granulocytes, monocytes) showed apoptosis and necrosis similar to that of their children. Therefore, we think that the parents of patients with other recessive SCN gene mutations (like G6PC3 and at least some of the unidentified mutations) might be heterozygous for the same genetic defect, like in the parents who were heterozygous for HAX1.

We think that the modifying effects of other genes or factors $[3,89]$ and any other accompanying neutropenia mutations [87] and many other factors that play roles in the transmission of disease, including the 159T $>C$ polymorphism in the same exon of $H A X 1$ mutation in patients with $H A X 1$ and other mutations as in other cases [90,91], both in the patients and parents, need to be evaluated in further studies.

The gingival enlargement and oral aphthae of the parents in the present study were thought to be possibly due to dysfunctional neutrophils, which were dysplastic at the same time, like a nonneutropenic mother of a patient with JAGN1 mutation who we followed before and had apoptosis in addition to morphological and functional abnormalities in neutrophils, lymphocytes, and thrombocytes with low levels of myeloperoxidase and defective chemotaxis $[8,10$, unpublished data].

Easy bruising and gingival bleeding of the parents were attributed to defective thrombocyte functions stemming from defective megakaryopoiesis.

We attribute apoptosis and secondary necrosis in the myeloid lineage of the non-neutropenic parents to the aforementioned genetic abnormalities relevant to $\mathrm{SCN}$, while those in the nongranulocytic cells to the high TNF-alpha levels [36] that can give rise to apoptosis in blood cells $[40,41,42,43,44,45,46]$, as discussed for children with SCN.

\section{Conclusion}

Apoptosis and secondary necrosis in non-granulocytic cell lines, dysplasia of blood cells with/without RCS, and disturbances in lymphocyte subsets and thrombocyte functions were observed in patients with congenital neutropenia and their non-neutropenic parents. Additionally, bone marrow of the patients showed increased phagocytic activity and striking dysmegakaryopoiesis. (Table 4). This study shows that abnormalities in lymphocyte subsets and hemorrhagic diathesis are not restricted to albinism- neutropenia syndromes, as current wisdom holds, but are also encountered in SCN.

Table 4. Summary of the findings.

- In our study, 15 patients with congenital neutropenia (6 had $H A X 1,2$ G6PC3, 2 ELANE, 5 unknown mutations) and 21 parents (5 had heterozygous HAX1 mutation) were evaluated.

- Significant increase in apoptosis and secondary necrosis in monocytes, lymphocytes, granulocytes of the patients and their parents was detected by flow cytometry irrespective of the type of congenital neutropenia mutation.

- Rapid cell senescence was additionally shown in 25\% and $12.5 \%$ of patients and parents respectively.

- Dysplasia was evident in neutrophils, monocytes, lymphocytes, thrombocytes in both patients and parents, by light and electron microscope.

- Bone marrow of the patients showed increased phagocytic activity, striking dysmegakaryopoiesis, necrotic and apoptotic cells.

- CD3 and CD4 lymphocytes and NK cells were decreased in 16.6\%, $8.3 \%$, and $36.4 \%$ of the patients and $0 \%, 0 \%$, and $15.4 \%$ of parents (controls: $0 \%, 0 \%, 5.6 \%$ ).

- The percentages of patients, parents, and controls with fewer than 2 dense granules/thrombocytes were 50\%, 35\%, and 0\%, respectively.

- In vitro bleeding time was prolonged by $37.5 \%$ and $33.3 \%$ in patients, and $18.8 \%$ and $12.5 \%$ in parents with different cartridges.

- Up to $63.6 \%$ and $44.4 \%$ of the aggregation tests displayed abnormality in patients and parents.

- Electron microscopic evaluation of thrombocyte aggregation revealed abnormality in two evaluated patients.

Moreover, our findings suggest that the pluripotent hematopoietic stem cells in SCN are defective irrespective of the genetic etiology, in contrast to the current thinking that understands the main defect as residing in the progenitor myeloid cells $[1,2,6]$, and myeloid transcriptional factors $[92,93]$.

\section{Study Limitations}

The main limitation of our study was that not all sub-studies could be performed for all cases due to daily limitations of our laboratory facilities. Including idiopathic neutropenic patients as a separate control group could have helped evaluate the results more extensively, although these patients were beyond the scope of this study. In spite of this, we believe that our results may lead to further in vivo and in vitro studies involving pluripotent hematopoietic stem cells in SCN so as to better understand the underlying physiopathology. Additionally, the presence of the same abnormalities in non-neutropenic parents shows that the phenotype-genotype relationship is another field that requires further evaluation.

\section{Acknowledgments}

This project was supported by the Turkish Society of Hematology (Project No: 06-B). We would like to thank all the patients 
and their families for kindly participating in our study. We are grateful to Prof. Nejat Akar, Aysel Pekel MD, Prof. Birkay Baştürk, and Associate Prof. Yunus Kasım Terzi for their valuable help and comments. We also thank Didem Özkazanç and Ahmet Gül from İstatistik Dünyası for doing the statistical analysis; Eren Çimen MA, Selma Şar, Hülya Dalgalı, Gül Ece Ulusan, and Esra Başyiğit for technical assistance; Murat Teberoğlu for his secretarial contribution; and our nurses for drawing blood from the patients.

\section{Ethics}

Ethics Committee Approval: Hacettepe University Ethics Committee (Number TBK 05/1-2).

Informed Consent: Informed consent was obtained from all individual participants included in the study.

\section{Authorship Contributions}

Surgical and Medical Practices: L.O., Ş.Ü.; Concept: L.O., S.Y.; Design: L.O., S.Y.; Data Collection or Processing: L.O., Ş.Ü., A.M., Y.Y.; Analysis or Interpretation: L.O., H.O., E.E., A.Ö., D.B., H.O., Y.B., A.I., M.F., G.Ö., S.Y.; Literature Search: L.O., H.O.; Writing: L.O., S.Y.

Financial Disclosure Statement: This project was supported by the Turkish Society of Hematology (Project No: 06-B).

Conflict of Interest Statement: The authors of this paper have no conflicts of interest, including specific financial interests, relationships, and/or affiliations relevant to the subject matter or materials included.

\section{References}

1. Özbek N. New insights into the genetics of congenital neutropenia. Turk J Hematol 2009;26:1-8.

2. Klein C. Genetic defects in severe congenital neutropenia: emerging insights into life and death of human neutrophil granulocytes. Ann Rev Immunol 2011;29:399-413.

3. Newburger PE, Pindyck TN, Zhu Z, Bolyard AA, Aprikyan AAG, Dale DC, Smith GD, Boxer LA. Cyclic neutropenia and severe congenital neutropenia in patients with a shared ELANE mutation and paternal haplotype: evidence for phenotype determination by modifying genes. Pediatr Blood Cancer 2010;55:314-317.

4. Donadieu J, Fenneteau O, Beaupain B, Mahlaoui N, Chantelot CB. Congenital neutropenia: diagnosis, molecular bases and patient management. Orphanet J Rare Dis 2011;6:26.

5. Boztug $K$, Järvinen PM, Salzer E, Racek T, Mönch S, Garncarz W, Gertz EM, Schäffer AA, Antonopoulos A, Haslam SM, Schieck L, Puchałka J, Diestelhorst J, Appaswamy G, Lescoeur B, Giambruno R, Bigenzahn JW, Elling U, Pfeifer D, Conde CD, Albert MH, Welte K, Brandes G, Sherkat $R$, van der Werff Ten Bosch J, Rezaei N, Etzioni A, Bellanné-Chantelot C, SupertiFurga G, Penninger JM, Bennett KL, von Blume J, Dell A, Donadieu J, Klein C. JAGN1 deficiency causes aberrant myeloid cell homeostasis and congenital neutropenia. Nat Genet 2014;46:1021-1027.

6. Aprikyan AA, Liles WC, Boxer LA, Dale DC. Mutant elastase in pathogenesis of cyclic and severe congenital neutropenia. J Pediatr Hematol Oncol 2002;24:784-786.
7. Ancliff PJ, Blundell MP, Cory GO, Calle $Y$, Worth A, Kempski H, Burns $S$, Jones GE, Sinclair J, Kinnon C, Hann IM, Gale RE, Linch DC, Thrasher AJ. Two novel activating mutations in the Wiskott-Aldrich syndrome protein result in congenital neutropenia. Blood 2006;108:2182-2189.

8. Olcay L, Yetgin S, Okur H, Erdemli E. Rapid cell senescence and apoptosis in lymphocytes and granulocytes and absence of GM-CSF receptor in congenital dysgranulopoietic neutropenia. Leuk Res 2008;32:235-242.

9. Ancliff PJ, Gale RE, Watts JM, Liesner R, Hann IM, Strobel S, Linch DC. Paternal mosaicism proves the pathogenic nature of mutations in neutrophil elastase in severe congenital neutropenia. Blood 2002;100:707709.

10. Olcay L, Yetgin S, Erdemli E, Germeshausen $M$, Aktaş $D$, Büyükaşik $Y$, Okur H. Congenital dysgranulopoietic neutropenia. Pediatr Blood Cancer 2008;50:115-119.

11. Shattil SJ, Abrams CS, Bennett JS. Acquired qualitative platelet disorders due to diseases, drugs and foods. In: Beutler E, Lichtman MA, Coller BS, Kipps TJ, Seligsohn U (eds). Williams Hematology. New York, McGraw-Hill, 2001.

12. İkincioğulları A, Kendirli $T$, Doğu $F$, Eğin $Y$, Reisli $I$, Cin Ş, Babacan E. Peripheral blood lymphocyte subsets in healthy Turkish children. Turk J Pediatr 2004;46:125-130.

13. Ormerod MG. Flow Cytometry: A Practical Approach. Oxford, Oxford University Press, 1994.

14. Olcay L, Tuncer AM, Okur H, Erdemli E, Uysal Z, Cetin M, Duru F, Cetinkaya DU. Excessive naked megakaryocyte nuclei in myelodysplastic syndrome mimicking idiopathic thrombocytopenic purpura: a complicated pre- and post-transplantation course. Pediatr Hematol Oncol 2009;26:387-397.

15. Dimri GP, Lee $X$, Basile $G$, Acosta $M$, Scott G, Roskelley $C$, Medrano EE, Linskens M, Rubelj I, Pereira-Smith O, Peacocke M, Campisi Jl. A biomarker that identifies senescent human cells in culture and in aging skin in vivo. Proc Natl Acad Sci U S A 1995;92:9363-9367.

16. Olcay $L$, Yetgin $S$, Okur $H$, Erekul $S$, Tuncer $M$. Dysplastic changes in idiopathic thrombocytopenic purpura and the effect of corticosteroids to increase dysplasia and cause hyperdiploid macropolycytes. Am J Hematol 2000;65:99-104.

17. Dykstra MJ. A Manual of Applied Techniques for Biological Electron Microscopy. New York, Plenum Press, 1993.

18. Buyukasik Y, Karakus S, Goker H, Haznedaroglu IC, Ozatli D, Sayinalp N, Ozcebe OI, Dundar SV, Kirazli S. Rational use of the PFA-100 device for screening of platelet function disorders and von Willebrand disease. Blood Coagul Fibrinolysis 2002;13:349-353.

19. Olcay L, Erdemli E, Kesimer M, Büyükasik Y, Okur H, Kalkanoğlu HS, Coskun T, Altay C. High cystine in platelets from patients with nephropathic cystinosis: a chemical, ultrastructural, and functional evaluation. J Clin Pathol 2005;58:939-945.

20. Komarnichi M, Pietrzak I, Zozulinska M. Mepacrine-labeled platelet densebody number in patients with chronic uremia. Nephron 1988;50:306-307.

21. Brugnara C. Reference values in infancy and childhood. In: Orkin SH, Nathan DG, Ginsburg D, Look AT, Fisher DE, Lux S (eds). Nathan and Oski's Hematology and Oncology of Infancy and Childhood. 8th ed. Philadelphia, Saunders, 2015.

22. Geaghan SM. Normal blood values for neonatal, pediatric and adult populations. In: Hoffman R, Benz EJ, Shattil SJ, Furie B, Cohen HJ, Silberstein LE, McGlave P (eds). Hematology: Basic Principles and Practice. 4th ed. Philadelphia, Churchill Livingstone, 2005.

23. Pintado $\mathrm{T}$, Maldonado JE. Ultrastructure of platelet aggregation in refractory anemia and myelomonocytic leukemia. I. Ultrastructure of aggregation in normal controls and general defects in refractory anemia and myelomonocytic leukemia. Mayo Clin Proc 1976;51:379-392.

24. Pintado T, Maldonado JE. Ultrastructure of platelet aggregation in refractory anemia and myelomonocytic leukemia. II. Individual platelet abnormalities: thrombasthenia-like platelets, surface defects, and dissociation phenomena. Mayo Clin Proc 1976;51:443-451. 
25. Courtney PA, Crockard AD, Williamson K, Irvine AE, Kennedy RJ, Bell AL. Increased apoptotic peripheral blood neutrophils in systemic lupus erythematosus: relations with disease. Ann Rheum Dis 1999;58:309-314.

26. Aprikyan AA, Liles WC, Park JR, Jonas M, Chi EY, Dale DC. Myelokathexis, a congenital disorder of severe neutropenia characterized by accelerated apoptosis and defective expression of bcl-x in neutrophil precursors. Blood 2000;95:320-327.

27. Liu JH, Wei S, Lamy T, Epling-Burnette PK, Starkebaum G, Djeu JY, Loughran TP. Chronic neutropenia mediated by Fas ligand. Blood 2000;95:3219-3222.

28. Cohen 0 , Cicala $C$, Vaccarezza $M$, Fauci AS. The immunology of human immunodeficiency virus infection. In: Mandell GL, Bennett JE, Dolin R, (eds). Principles and Practice of Infectious Diseases. New York, Churchill Livingstone, 2000.

29. Uguz A, Coskun M, Yuzbey S, Kizilors A, Karadogan I, Gura A, Yoldas B, Oygur $\mathrm{N}$, Yegin 0 . Apoptosis of cord blood neutrophils and their response to colony-stimulating factors. Am J Perinatol 2002;19:427-433.

30. Papadaki HA, Eliopoulos AG, Kosteas T, Gemetzi C, Damianaki A, Koutala $H$, Bux J, Eliopoulos GD. Impaired granulocytopoiesis in patients with chronic idiopathic neutropenia is associated with increased apoptosis of bone marrow myeloid progenitor cells. Blood 2003;101:2591-2600.

31. Kuijpers TW, Maianski NA, Tool AT, Smit GP, Rake JP, Roos D, Visser G. Apoptotic neutrophils in the circulation of patients with glycogen storage disease type 1b (GSD1b). Blood 2003;101:5021-5024.

32. Cohen GM, Sun XM, Snowden RT, Dinsdale D, Skilleter DN. Key morphological features of apoptosis may occur in the absence of internucleosomal DNA fragmentation. Biochem J 1992;286:331-334.

33. Poon IK, Lucas CD, Rossi AG, Ravichandran KS. Apoptotic cell clearance: basic biology and therapeutic potential. Nat Rev Immunol 2014;14:166180

34. Abbas AK, Lichtman AH, Pillai S. Innate immunity. In: Abbas A, Lichtman $A H$, Pillai S (eds). Cellular and Molecular Immunology. 8th ed. Toronto, Elsevier Saunders, 2015.

35. Abbas AK, Lichtman AH, Pillai S. Differentiation and functions of CD4+ effector T cells. In: Abbas A, Lichtman AH, Pillai S (eds). Cellular and Molecular Immunology. 8th ed. Toronto, Elsevier Saunders, 2015.

36. Olcay L, Ünal Ş, Öztürk $A$, Erdemli E, Billur D, Metin A, Okur H, İkincioğulları A, Yıldırmak Y, Büyükaşık Y, Yılmaz-Falay M, Özet G, Yetgin S. Granulocytic and non granulocytic lineages in children with congenital neutropenia and their non neutropenic parents: biochemical, functional, morphological and genetic evaluation. Haematologica 1012;97(Suppl 3):065a (abstract).

37. Shitara $T$, Yugami $S$, ljima $H$, Sotomatu $M$, Kuroume T. Cytokine profile during high-dose rhG-CSF therapy in severe congenital neutropenia. Am J Hematol 1994;45:58-62.

38. Koval'chuk LV, Khoreva MV, Nikonova AS, Finogenova NA, Mamedova EA, Polovtseva TV, Fetisova Lla, Gracheva LA, Goldyreva NG. Toll-like receptormediated functional activity of mononuclear cells in children with neutropenia. Zh Mikrobiol Epidemiol Immunobiol 2010;2:64-68.

39. Bohn G, Hardtke-Wolenski M, Zeidler C, Maecker B, Sauer M, Sykora KW, Grigull L, Welte K, Klein C. Lethal graft-versus-host disease in congenital neutropenia caused by p14 deficiency after allogeneic bone marrow transplantation from an HLA-identical sibling. Pediatr Blood Cancer 2008:51:436-438.

40. Geering B, Simon HU. A novel signaling pathway in TNF $\alpha$-induced neutrophil apoptosis. Cell Cycle 2011;10:2821-2822.

41. Ugan $Y$, Nazıroğlu $M$, Şahin $M$, Aykur M. Anti-tumor necrosis factor alpha (Infliximab) attenuates apoptosis, oxidative stress, and calcium ion entry through modulation of cation channels in neutrophils of patients with ankylosing spondylitis. J Membr Biol 2016;249:437-447.

42. Bommhardt U, Chang KC, Swanson PE, Wagner TH, Tinsley KW, Karl IE, Hotchkiss RS. Akt decreases lymphocyte apoptosis and improves survival in sepsis. J Immunol 2004;172:7583-7591.

43. Hotchkiss RS, Tinsley KW, Karl IE. Role of apoptotic cell death in sepsis. Scand J Infect Dis 2003;35:585-592.
44. Kawakami Y, Tsukimoto M, Kuwabara K, Fujita T, Fujino O, Kojima S, Fukunaga Y. Tumor necrosis factor- $\alpha$-induced mononuclear cell death may contribute to polymorphonuclear cell predominance in the cerebrospinal fluid of patients with bacterial meningitis. J Nippon Med Sch 2011;78:360-366.

45. Cevik O, Adiguzel Z, Baykal AT, Somay G, Sener A. The apoptotic actions of platelets in acute ischemic stroke. Mol Biol Rep 2013;40:6721-6727.

46. Kawada J, Kimura H, Shibata $Y$, Hara S, Hoshino Y, Kojima S, Nishikawa $\mathrm{K}$, Morishima T. Evaluation of apoptosis in Epstein-Barr virus-associated hemophagocytic lymphohistiocytosis. J Med Virol 2006;78:400-407.

47. Ochs HD, Notarangelo LD. Structure and function of the Wiskott-Aldrich syndrome protein. Curr Opin Hematol 2005;12:284-291.

48. Jung J, Bohn G, Allroth A, Boztug K, Brandes G, Sandrock I, Schäffer AA, Rathinam C, Köllner I, Beger C, Schilke R, Welte K, Grimbacher B, Klein C. Identification of a homozygous deletion in the AP3B1 gene causing Hemansky-Pudlak syndrome, type 2. Blood 2006;108:362-369.

49. Wei ML. Hermansky-Pudlak syndrome: a disease of protein trafficking and organelle function. Pigment Cell Res 2006;19:19-42.

50. Zhu J, Davidson TS, Wei G, Jankovic D, Cui K, Schones DE, Guo L, Zhao $\mathrm{K}$, Shevach EM, Paul WE. Down-regulation of Gfi-1 expression by TGFB is important for differentiation of Th17 and CD103+ inducible regulatory $T$ cells. J Exp Med 2009;206:329-341.

51. Dinauer MC, Newburger PP. The phagocyte system and disorders of granulopoiesis and granulocyte function. In: Orkin SH, Nathan DG, (eds). Nathan and Oski's Hematology of Infancy and Childhood. Philadelphia, Saunders Elsevier, 2009.

52. Jaeger BN, Donadieu J, Cognet $C$, Bernat $C$, Ordoñez-Rueda D, Barlogis $V$ Mahlaoui N, Fenis A, Narni-Mancinelli E, Beaupain B, Bellanné-Chantelot C,

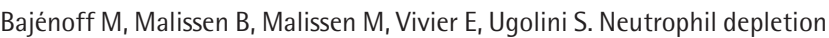
impairs natural killer cell maturation, function, and homeostasis. J Exp Med 2012;209:565-580.

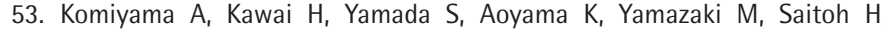
Miyagawa $Y$, Akabane T, Uehara Y. Impaired natural killer cell recycling in childhood chronic neutropenia with morphological abnormalities and defective chemotaxis of neutrophils. Blood 1985;66:99-105.

54. McElhaney JE, Effros RB. Immunosenescence: what does it mean to health outcomes in older adults? Curr Opin Immunol 2009;21:418-424.

55. Freund A, Orjalo AV, Desprez PY, Campisi J. Inflammatory networks during cellular senescence: causes and consequences. Trends Mol Med 2010;16:238-246.

56. Olcay L, Billur D, Erdemli E, Baskin SE, Balci HF, Yetgin S. Myelodysplastic features and cellular senescence in autoimmune disorders: a pilot study on patients with collagen tissue disorders and immune thrombocytopenic purpura. Turk J Med Sci 2015;45:742-744.

57. Chang BD, Xuan Y, Broude EV, Zhu H, Schott B, Fang J, Roninson IB. Role of $p 53$ and $p 21$ waf1/cip1 in senescence-like terminal proliferation arrest induced in human tumor cells by chemotherapeutic drugs. Oncogene 1999;18:4808-4818.

58. O'Connor PM, Jackman J. Assessment of DNA damage cell cycle checkpoints in $\mathrm{G} 1$ and $\mathrm{G} 2$ phases of mammalian cells. In: Studzinski GP, Robertson GP, Hufford A, Lugo TG, (eds). Cell Growth, Differentiation and Senescence: A Practical Approach. New York, Oxford University Press, 1999.

59. Hubbard K, Ozer HL. Senescence and immortalization of human cells. In: Studzinski GP, Robertson GP, Hufford A, Lugo TG, (eds). Cell Growth, Differentiation and Senescence: A Practical Approach. New York, Oxford University Press, 1999.

60. Ly DH, Lockhart DJ, Lerner RA, Schultz PG. Mitotic misregulation and human aging. Science 2000;287:2486-2492.

61. Gorbunova V, Seluanov A, Pereira-Smith OM. Expression of human telomerase (hTERT) does not prevent stress-induced senescence in normal human fibroblasts but protects the cells from stress-induced apoptosis and necrosis. J Biol Chem 2002;277:38540-38549. 
62. Wright WE, Shay JW. Historical claims and current interpretations of replicative aging. Nat Biotechnol 2002;20:682-688.

63. Rodier F, Campisi J. Four faces of cellular senescence. J Cell Biol 2011;192:547-556.

64. Ohtani N, Hara E. Roles and mechanisms of cellular senescence in regulation of tissue homeostasis. Cancer Sci 2013;104:525-530.

65. Macieira-Coelho A. Chromatin reorganization during senescence of proliferating cells. Mutat Res 1991;256:81-104.

66. Parmley RT, Crist WM, Ragab AH, Boxer LA, Malluh A, Lui VK, Darby CP. Congenital dysgranulopoietic neutropenia: clinical, serologic, ultrastructural, and in vitro proliferative characteristics. Blood 1980;56:465-475.

67. Olcay $\mathrm{L}$, Yetgin $\mathrm{S}$. Disorders mimicking myelodysplastic syndrome and difficulties in its diagnosis. In: Fuchs 0, (ed). Myelodysplastic Syndromes. Rijeka, InTech, 2016.

68. Lightsey AL, Parmley RT, Marsh WL Jr, Garg AK, Thomas WJ, Wolach B, Boxer LA. Severe congenital neutropenia with unique features of dysgranulopoiesis. Am J Hematol 1985;18:59-71.

69. Thiele J, Lorenzen J, Manich B, Kvasnicka HM, Zirbes TK, Fischer R. Apoptosis (programmed cell death) in idiopathic (primary) osteo-/myelofibrosis: naked nuclei in megakaryopoiesis reveal features of para-apoptosis. Acta Haematol 1997;97:137-143.

70. Centurione L, Di Baldassarre A, Zingariello $M$, Bosco D, Gatta V, Rana RA, Langella V, Di Virgilio A, Vannucchi AM, Migliaccio AR. Increased and pathologic emperipolesis of neutrophils within megakaryocytes associated with marrow fibrosis in GATA-1(low) mice. Blood 2004;104:3573-3580.

71. Aslan D, Yetgin S. Megakaryocyte emperipolesis in a child with chronic neutropenia: an unusual coexistence. Turk J Pediatr 2001;43:255-256.

72. Houwerzijl EJ, Blom NR, van der Want JJ, Esselink MT, Koornstra JJ, Smit JW, Louwes $H$, Vellenga $E$, de Wolf JT. Ultrastructural study shows morphologic features of apoptosis and para-apoptosis in megakaryocytes from patients with idiopathic thrombocytopenic purpura. Blood 2004;103:500-506.

73. Erber WN, Jacobs A, Oscier DG, O'Hea AM, Mason DY. Circulating micromegakaryocytes in myelodysplasia. J Clin Pathol 1987;40:1349-1352.

74. Cowan DH, Graham RC, Baunach D. The platelet defect in leukemia. Platelet ultrastructure, adenine nucleotide metabolism, and the release reaction. J Clin Invest 1975;56:188-200.

75. Rao AK. Inherited platelet function disorders: overview and disorders of granules, secretion, and signal transduction. Hematol Oncol Clin North Am 2013;27:585-611.

76. Klein C. Congenital neutropenia. Hematology Am Soc Hematol Educ Program 2009;344-350.

77. Nieuwenhuis HK, Akkerman JW, Sixma JJ. Patients with a prolonged bleeding time and normal aggregation tests may have storage pool deficiency: studies on one hundred and six patients. Blood 1987;70:620-623.

78. Jasty R, Kuerbitz $S$, Matthew P. Correlation of clinical severity of bleeding with electron microscopy findings in a group of pediatric patients with platelet storage pool deficiencies at a single institution. J Pediatr Hematol Oncol 2001;23:1146a (abstract).

79. Sladky JL, Klima J, Grooms L, Kerlin BA, O'Brien SH. The PFA-100 ${ }^{\circledR}$ does not predict delta-granule platelet storage pool deficiencies. Hemophilia 2012;18:626-629.

80. White JG. Use of the electron microscope for diagnosis of platelet disorders. Semin Thromb Hemost 1998;24:163-168.

81. Ancliff PJ, Gale RE, Watts JM, Liesner R, Hann IM, Strobel S, Linch DC. Paternal mosaicism proves the pathogenic nature of mutations in neutrophil elastase in severe congenital neutropenia. Blood 2002;100:707-709.

82. Hirata 0 , Okada S, Tsumura M, Karakawa $S$, Matsumura I, Kimura $Y$, Maihara T, Yasunaga S, Takihara $Y$, Ohara 0 , Kobayashi M. Mosaicism of an ELANE mutation in an asymptomatic mother in a familial case of cyclic neutropenia. J Clin Immunol 2015;35:512-516.

83. Kim HJ, Song MJ, Lee KO, Kim SH, Kim HJ. Paternal somatic mosaicism of a novel frameshift mutation in ELANE causing severe congenital neutropenia. Pediatr Blood Cancer 2015;62:2229-2231.

84. Malcov M, Reches A, Ben-Yosef D, Cohen T, Amit A, Dgany O, Tamary H, Yaron $Y$. Resolving a genetic paradox throughout preimplantation genetic diagnosis for autosomal dominant severe congenital neutropenia. Prenat Diagn 2010;30:207-211.

85. Ancliff PJ, Gale RE, Liesner R, Hann IM, Linch DC. Mutations in the ELA2 gene encoding neutrophil elastase are present in most patients with sporadic severe congenital neutropenia but only in some patients with the familial form of the disease. Blood 2001;98:2645-2650.

86. Sippel KC, Fraioli RE, Smith GD, Schalkoff ME, Sutherland J, Gallie BL, Dryja TP. Frequency of somatic and germ-line mosaicism in retinoblastoma: implications for genetic counseling. Am J Hum Genet 1998;62:610-619.

87. Skokowa J, Dale DC, Touw IP, Zeidler C, Welte K. Severe congenital neutropenias. Nat Rev Dis Primers 2017;3:17032.

88. Haurie C, Dale DC, Mackey MC. Occurrence of periodic oscillations in the differential blood counts of congenital, idiopathic, and cyclical neutropenic patients before and during treatment with G-CSF. Exp Hematol 1999;27:401-409.

89. Jaloma-Cruz AR, Beltran-Miranda CP, Gonzalez-Ramos IA, Lopez-Jimenez JJ, Luna-Zaizar H, Mantilla-Capacho JM, Mundo-Ayala JN, Galvan MJV. Genotype-phenotype interaction analyses in hemophilia. In: Batorova $A_{\text {, }}$ (ed). Hemophilia. Rijeka, InTech, 2012.

90. Steinemann D, Praulich I, Otto N, Göhring G, Niemeyer CM, Schlegelberger B. Mutation analysis of the $H A X 1$ gene in childhood myelodysplastic syndrome. Br J Haematol 2009;145:533-550.

91. Park J, Kim M, Lim J, Kim Y, Cho B, Park JY, Han K. Molecular analysis of two cases of severe congenital neutropenia. Korean J Lab Med 2010;30:111-116.

92. Skokowa J, Welte K. Dysregulation of myeloid-specific transcription factors in congenital neutropenia. Ann N Y Acad Sci 2009;1176:94-100.

93. Skokowa J, Fobiwe JP, Dan L, Thakur BK, Welte K. Neutrophil elastase is severely down-regulated in severe congenital neutropenia independent of ELA2 or HAX1 mutations but dependent on LEF-1. Blood 2009;114:3044-3051. 


\title{
Appendix: Supplemental Materials and Methods
}

\section{Mutation Analysis}

Mutation analyses of the HAX1, ELANE, CSF3R, and G6PC3 genes were performed by standard techniques using a DNA sequencing kit (PerkinElmer, Foster City, CA, USA) and the ABI Prism 3100 sequence analyzer (Applied Biosystems, Foster City, CA, USA).

\author{
HAX1 (NM_006118) \\ ELANE (NM_001972) \\ CSF3R (NM_156039) \\ G6PC3 (NM_138387) \\ JAGN1 (NM_032492)
}

Reference accession number of the genes

\section{Evaluation of Cellular Morphology}

The peripheric blood cells were evaluated by light (Nikon Eclipse E400, Nikon Corporation, Japan) and transmission electron microscope (TEM) (LEO 906E, Zeiss, Germany) for apoptosis and dysmorphism [1,2,3,4], in a blinded fashion. One hundred neutrophils of the parents (except YF's mother whose peripheral blood smear enabled us to evaluate only 50 neutrophils) and control group were scored for dysmorphism under light microscope (1000x). Each dysmorphic feature shown by an individual neutrophil was given one score and the total score for a definite dysmorphic feature was presented as '\%'. Only for YF's mother the total score for a definite dysmorphic feature was multiplied by two. The patients' neutrophils could not be scored due to neutropenia. The photographs of the representative cells with dysmorphic features under electron microscope were taken and presented.

\section{Evaluation of the Thrombocytes of the Patients and the Parents}

In vitro bleeding time: This was measured by a PFA-100 instrument (Dade Behring Marburg GmbH, Marburg, Germany) using collagenepinephrine and/or collagen-ADP cartridges [5].

Turbidimetric aggregation tests: A Chrono-Log 560 Ca aggregometer was used with minor modifications (Chrono-Log Corporation, Havertown, PA, USA) [5]. Thrombocyte aggregation was studied with collagen ( 1 and $2 \mu \mathrm{g} / \mathrm{mL}$ ), ristocetin $(1.25 \mathrm{mg} / \mathrm{mL})$, $\operatorname{ADP}(2,6,10 \mu \mathrm{M})$, and epinephrine $(10 \mu \mathrm{M})$.

Mepacrine labeling of dense granules: Thrombocyte-rich plasma was prepared and stained with mepacrine $(1 \mu \mathrm{M}$; Sigma, St. Louis, M0, USA) as described previously [6,7]. The greenish-yellow fluorescent dense granules were visualized under a fluorescent microscope (Zeiss Axoscope; Zeiss, Thornwood, NY, USA). The dense granules were counted in 84-106 platelets for each sample. The results were presented as the mean dense granule number per thrombocyte $[6,7]$.

Electron microscopic evaluation of aggregation: After adding $2 \mu \mathrm{M}$ ADP to thrombocyte-rich plasma obtained from two patients (BA, $\mathrm{ZG})$, samples were removed at the $2^{\text {nd }}, 8^{\text {th }}$, and $14^{\text {th }}$ minutes and were prepared for TEM [6].

\section{Statistics}

We used SPSS 15.0 to evaluate the data we obtained (SPSS Inc., Chicago, IL, USA). A normality test was performed to determine if the data were distributed in a normal fashion. To compare evenly and unevenly distributed data, we used the independent samples t-test and the Mann-Whitney $U$ test (for two groups) and One-way ANOVA and the Kruskal-Wallis $\mathrm{H}$ test with Bonferroni correction (for more than two groups). We used the Scheffe test in the one-way ANOVA testing to determine which groups had differences between themselves. One-sample t-tests were used to evaluate whether the means of the variables differed from the means of the reference group. Values of $p<0.05$ and $p<0.017$ were considered significant for inter-group comparison and the Kruskal-Wallis $\mathrm{H}$ test, respectively.

\section{Supplemental Results \\ Ultrastructural View of Aggregating Thrombocytes}

Aggregation tests under TEM revealed the following abnormalities: 1) Lack of adhesion: At the $2^{\text {nd }}, 8^{\text {th }}$, and $14^{\text {th }}$ minutes of the aggregation test, the thrombocytes were still separate from each other. At the second minute, the granules were fairly or completely centralized with no visible pseudopods, whereas normal thrombocytes fit together tightly, displayed abundant blunt pseudopods, and had released almost all of their granules (Case 1, Case 2, and control). 2) Lack of or inadequate secretion: Organelle centralization took place but the organelles later became dispersed in the cytoplasm, without undergoing secretion and with

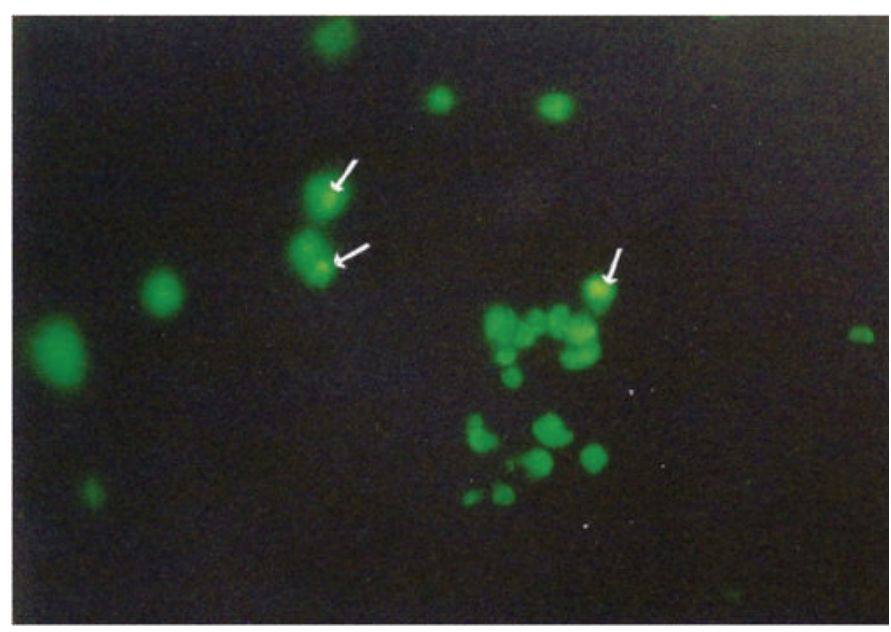

Supplemental Figure 1. The platelet dense granules stained by mepacrine (arrow). 


\begin{tabular}{|c|c|}
\hline \multicolumn{2}{|c|}{$\begin{array}{l}\text { Supplemental Table 1. Primers used for the } \\
\text { sequencing of the coding regions of } H A X 1, E L A N E \text {, } \\
G 6 P C 3, C S F 3 R, J A G N 1 \text { genes. }\end{array}$} \\
\hline HAX1-1F & ACTGGAGGGGTTCAAAGGT \\
\hline HAX1-1R & ATCACCCC AGGTTGGAGAA \\
\hline$H A X 1-2 F$ & TCC CACTTGGCACCCATGAGT \\
\hline HAX1-2R & ПТТТСАСАСПТССАТСССС \\
\hline HAX1-3F & ССПТСССАТСССAGCAAACACC \\
\hline HAX1-3R & CT CACAAGCTCTCACTCAGGACCA \\
\hline HAX1-4F & G GGGTTIGGAGCTCGGGAGTAGT \\
\hline HAX1-4R & TCAGGGAGGGAGAACACACAG A \\
\hline HAX1-5,6F & СTCСTGCTСТTСАTСTCTC TGCTC \\
\hline HAX1-5,6R & AGGCAGAAGCAAAGGACAAGGG \\
\hline HAX1-7F & CTCAAGATCCTGGGGAAG \\
\hline HAX1-7R & CGGAAGTGTTGGAT GGTTCT \\
\hline ELANE-2,3F & CGGAGGGGCAGAGACCCCGGA \\
\hline ELANE-2,3R & AGACCGGGACGCGGGGTCCGA \\
\hline ELANE-4F & CTCGAGCACCTTCGCCCTCAG \\
\hline ELANE-4R & TCAACGGCCCATGGCGGGTAT \\
\hline ELANE-5-6F & CCTGCCCTGCAGGATCCCAGA \\
\hline ELANE-5-6R & GGAGAGTGTGGGTGTGGGCAG \\
\hline CSF3R-3R & AAGGAAATСCCAATATCTCTCC \\
\hline CSF3R-4F & CCAGGGTCTGCTITCTCTG \\
\hline CSF $3 R-4 R$ & AGGCACCCGCCACTATG \\
\hline CSF3R-5-6F & AGGAAGCTTTCTGAGTGGTCC \\
\hline CSF3R-5-6R & TGTGTTСССТСТССАПСС \\
\hline CSF3R-7-8F & AGAGCCCTCTAGGGTGGG \\
\hline CSF3R-7-8R & GGGGCCTGGACTGGATAC \\
\hline CSF3R-9F & GTATCCAGTCCAGGCCCC \\
\hline CSF3R-9R & CTAAGCCCCGGTTGTAGG \\
\hline CSF3R-10F & СCTAGAGGCTCTCCTGACTC \\
\hline CSF3R-10R & CCAGGCAGTCTAGCCTTG \\
\hline CSF3R-11F & CAGGCTTCTGGCTCAAGG \\
\hline CSF3R-11R & TCAGATAAGCACTGCCTCCC \\
\hline CSF $3 R-12 F$ & GCTCCTGATCATTAGCACAGG \\
\hline CSF3R-12R & AGAGCCTGGGAGAGAGAGG \\
\hline CSF3R-13-14F & AGAAGTCCAACCGGGCTC \\
\hline CSF3R-13-14R & AAATCAGCATCCTTTGGGTG \\
\hline CSF3R-15-16F & AGACCCAGCCTTCCCAAC \\
\hline CSF3R-15-16R & CTGGCTCAGAAGGTGTCC \\
\hline CSF3R-17F & CCAGACAGGGACAGTGGC \\
\hline CSF3R-17R & AСССТССССТСТСТССАG \\
\hline G6PC3-1F & GTGATAGCCGAGGCGCTACAG \\
\hline G6PC3-1R & AGGGCTTACACATGACTCAGGG \\
\hline G6PC3-2F & GAGTACTCTGTGTCCTGCCCG \\
\hline G6PC3-2R & CTCTGAAATGTTCACCCGAACC \\
\hline G6PC3-3F & CAGCTGTATATTGAGGCATCACC \\
\hline G6PC3-3R & GCCATGCTGCTGTGTCTATAGG \\
\hline G6PC3-4F & TCAACCATGGAGTACCTGGG \\
\hline G6PC3-4R & GTGGGCTCTACAGAAGCTGGG \\
\hline G6PC3-5F & АПСТCTGCCAAGCTGCACTG \\
\hline G6PC3-5R & AGGCTAGGTGCAGGCGAGATAG \\
\hline G6PC3-6aF & GATAGCCTGCCTGTGCTGG \\
\hline G6PC3-6aR & CGGAAGCAGATTAGGGAGGG \\
\hline G6PC3-6bF & CAGTGGCCTCTATGTTCCAGC \\
\hline G6PC3-6bR & GGCCAGAGGGTGTACTTAGG \\
\hline JAGN1_1F & GTGTCGTGCGGTACCAGG \\
\hline JAGN1_1R & GGGGAGCAAGACCCTGAG \\
\hline JAGN1_2F & TGTCTGGCATATAGTGGTGG \\
\hline JAGN1_2R & AAGGGATTTGGAACCGC \\
\hline
\end{tabular}

unevacuated large granules and no enlargement in the OCS (Case 2) or having made partial secretion with enlarged OCS full of unsecreted material (Cases 1 and 2). 3) Delay in all stages of aggregation: Each stage of aggregation (centralization, development of pseudopods, and/or absent or impartial secretion) took place with delay (Case 1, Case 2, and control). 4) Abnormal degranulation: Unlike in normal degranulation, in which the dissolution of the granule's membrane is followed by evacuation of granule contents into the OCS and canalicular dilation, in some samples of the patients the dense granule was evident in the OCS, without membrane dissolution (Case 1). 5) Dissociation phenomenon: The patients' platelets showed the dissociation phenomenon, a disruption of normal aggregation that normally takes place in a coordinated sequence of pseudopod formation, change in shape, clustering of central granules, degranulation, and canalicular dilation $[8,9]$. In our cases, all of these changes took place without the adherence of thrombocytes to each other. We observed OCS enlargement and secretion of some material taking place before the degranulation phase ended (Case 1). 6) Abnormal cytoplasmic protrusions: The cytoplasmic protrusions in normal aggregating thrombocytes were thin, whereas in our patients they were amoeboid (Cases 1 and 2).

\section{Clinical Correlations Between Hemorrhagic Diathesis and Laboratory Parameters}

It was striking that not all cases with a history of hemorrhagic diathesis displayed abnormal aggregation test results, low dense granule number in thrombocytes, or prolonged in vitro bleeding time, whereas many cases without any history of hemorrhagic diathesis displayed abnormal aggregation test results or low dense granule number in thrombocytes or prolonged bleeding time or abnormal ultrastructure of thrombocytes. Not all of these abnormalities coexisted all together (Table 2; Supplemental Table 5).

\section{Supplemental Discussion \\ Text 1}

In the steady state apoptotic cells are rarely encountered under physiological conditions and the removal of the apoptotic cells is fast and promotes an anti-inflammatory response [10]. However, in the case of substantial and excessive apoptosis during which the capacity of phagocytes to engulf apoptotic cells is reduced, the uncleared apoptotic cells and fragments undergo secondary necrosis (delayed apoptotic clearance) which can provoke inflammation or autoimmunity. Macrophages that ingest necrotic cells cause increased T cell proliferation [10].

Hence, the flow cytometric graphics show that apoptotic and necrotic cells coexisted in all three cell lines, confirming that necrosis was due to excessive apoptosis. Hence, phagocytosis of both necrotic and apoptotic cells were shown in the bone marrow of the patients.

However, presence of excessive apoptosis and secondary necrosis not only in the patients' neutrophils but in all other cell lines (lymphocytic and monocytic) regardless of the mutation type of congenital neutropenia and their existence even in the non-neutropenic parents of the congenital neutropenia patients seem unreliable at first glance.

We think that macrophages of our patients were activated by increased apoptosis in the myeloid lineage, and the TNF-alpha secreted by activated macrophages gave rise to increased apoptosis (and secondary necrosis) in all cell lineages. Hence, striking phagocytic activity of various phagocytic cells (histiocytes, monocytes, macrophages, neutrophils, bands and even eosinophils and eosinophil myelocytes), mainly being monocytic cells, and our previous findings showing elevated TNF-alpha which is mainly secreted by activated macrophages in a group of congenital neutropenia patients, most of whom also enrolled in this study [11], confirm our explanation. 


\begin{tabular}{|c|c|c|c|c|c|c|c|c|}
\hline & Age & Symptoms / findings & Molecular genetics & \begin{tabular}{|l|} 
Leukocyte \\
count \\
(WBC; x109/L) \\
$(n=4.0-10.0)$
\end{tabular} & $\begin{array}{l}\text { Neutrophil } \\
\text { count } \\
\left(10^{9} / \mathrm{L}, \%\right) \\
(\mathrm{n}=1.9-8.0)\end{array}$ & $\begin{array}{l}\text { Monocyte } \\
\text { count } \\
\left(x 10^{9} / L, \%\right) \\
(n=0.12-1.2)\end{array}$ & $\begin{array}{l}\text { Lymphocyte } \\
\text { count } \\
\left(x 10^{9} / \mathrm{L}, \%\right) \\
(\mathrm{n}=0.9-5.2)\end{array}$ & $\begin{array}{l}\text { Thrombocyte } \\
\text { count } \\
\left(\times 10^{9} / L, \%\right) \\
(n=130-400)\end{array}$ \\
\hline Father of MK & $38 y$ & - & $\mathrm{NA}^{+}$ & 7.0 & 3.6 & 0.8 & 2.5 & 365 \\
\hline $\begin{array}{l}\text { Mother of MNY- } \\
\text { AY siblings* }\end{array}$ & $34 y$ & - & $\begin{array}{l}\text { HAX1 heterozygousc.130- } \\
131 \text { insA (p.W44X)** }\end{array}$ & 8.3 & 5.2 & 0.5 & 2.5 & 312 \\
\hline $\begin{array}{l}\text { Father of MNY- } \\
\text { AY siblings* }\end{array}$ & $37 y$ & - & $\begin{array}{l}\text { HAX1 heterozygous } \\
\text { c.130-131insA (p.W44X)** }\end{array}$ & 8.48 & 5.77 & 0.62 & 1.8 & 304 \\
\hline $\begin{array}{l}\text { Mother of MeK- } \\
\text { OSK siblings }\end{array}$ & $55 y$ & - & $\mathrm{NA}^{+}$ & 9.24 & 4.38 & 0.77 & 3.91 & 314 \\
\hline $\begin{array}{l}\text { Father of MeK- } \\
\text { OSK siblings }\end{array}$ & $54 y$ & - & $\mathrm{NA}^{+}$ & 8.7 & 5.6 & 0.8 & 2.1 & 322 \\
\hline Mother of $\mathrm{AF}^{*}$ & $28 y$ & Gingival enlargement & $\mathrm{NA}^{+}$ & 8.8 & 5.4 & 0.8 & 2.3 & 247 \\
\hline Father of AF & $32 y$ & Frequent aphthae & $\mathrm{NA}^{+}$ & 8.9 & 5.6 & 0.7 & 2.3 & 211 \\
\hline Mother of $\mathrm{EC}^{*}$ & $26 y$ & $\begin{array}{l}\text { Gingival enlargement } \\
\text { gingival bleeding }\end{array}$ & $\begin{array}{l}\text { HAX1 heterozygous } \\
\text { c. } 130-131 \text { ins } A(p . W 44 X) * *\end{array}$ & 6.82 & 4.26 & 0.61 & 1.80 & 241 \\
\hline Father of $\mathrm{EC}^{*}$ & $25 y$ & - & $N A^{*}$ & 8.32 & 5.37 & 0.57 & 2.07 & 238 \\
\hline Mother of $\mathrm{HY}^{*}$ & $29 y$ & - & \begin{tabular}{|l} 
HAX1 heterozygous \\
c. $130-131$ insA (p.W44X)
\end{tabular} & 7.38 & 4.75 & 0.52 & 1.94 & 268 \\
\hline Father of $\mathrm{HY}^{*}$ & $32 y$ & - & $\begin{array}{l}\text { HAX1 heterozygous } \\
\text { c.130-131insA (p.W44X)** }\end{array}$ & 10.15 & 5.87 & 0.70 & 3.18 & 287 \\
\hline Mother of $\mathrm{RT}^{*}$ & $30 y$ & - & No ELANE ${ }^{* * *}$ & 10.0 & 7.3 & 0.3 & 2.3 & 261 \\
\hline Father of $\mathrm{RT}^{*}$ & $34 y$ & - & No ELANE ${ }^{* * *}$ & 14.1 & 11.3 & 0.6 & 2.1 & 280 \\
\hline Mother of NBÖ* & $46 y$ & Easy bruising & No ELANE $E^{* * *}$ & 4.7 & 2.8 & 0.3 & 1.6 & 242 \\
\hline Father of NBÖ* & $49 y$ & - & No ELANE $E^{* * *}$ & 5.1 & 2.3 & 0.5 & 2.1 & 251 \\
\hline Mother of $\mathrm{AO}$ & 29 & Easy bruising & $\mathrm{NA}^{+}$ & 7.9 & 5.2 & 0.4 & 2.2 & 361 \\
\hline Father of $\mathrm{AO}$ & $36 y$ & Gingival enlargement & $\mathrm{NA}^{+}$ & 8.0 & 4.8 & 0.48 & 2.4 & 328 \\
\hline Mother of BA & $32 y$ & - & $\mathrm{NA}^{+}$ & 6.4 & 4.0 & 0.4 & 1.9 & 366 \\
\hline Father of BA & $38 y$ & Easy bruising & $\mathrm{NA}^{+}$ & 9.4 & 6.3 & 0.6 & 2.2 & 248 \\
\hline $\begin{array}{l}\text { Mother of AG- } \\
\text { ZG siblings* }\end{array}$ & $23 y$ & - & $\mathrm{NA}^{+}$ & 6.7 & 3.6 & 0.56 & 2.24 & 205 \\
\hline $\begin{array}{l}\text { Father of AG-ZG } \\
\text { siblings* }\end{array}$ & $27 y$ & Easy bruising & $\mathrm{NA}^{+}$ & 6.84 & 3.88 & 0.57 & 2.12 & 227 \\
\hline
\end{tabular}

\begin{tabular}{|c|c|c|c|c|c|c|c|c|c|c|}
\hline \multicolumn{11}{|c|}{$\begin{array}{l}\text { Supplemental Table } 3 \text {. The number } \\
\text { and above age matched normal ran } \\
\text { CD3 }\end{array}$} \\
\hline & \begin{tabular}{|l|} 
Below \\
normal
\end{tabular} & $\begin{array}{l}\begin{array}{l}\text { Above } \\
\text { normal }\end{array} \\
\end{array}$ & \begin{tabular}{|l|} 
Below \\
normal
\end{tabular} & $\begin{array}{l}\text { Above } \\
\text { normal }\end{array}$ & $\begin{array}{l}\text { Below } \\
\text { normal }\end{array}$ & $\begin{array}{l}\begin{array}{l}\text { Above } \\
\text { normal }\end{array} \\
\end{array}$ & $\begin{array}{l}\text { Below } \\
\text { normal }\end{array}$ & $\begin{array}{l}\text { Above } \\
\text { normal }\end{array}$ & $\begin{array}{l}\text { Below } \\
\text { normal }\end{array}$ & $\begin{array}{l}\begin{array}{l}\text { Above } \\
\text { normal }\end{array} \\
\end{array}$ \\
\hline \multirow{2}{*}{ Patients $(n=11)$} & 2 & 2 & 1 & 0 & 0 & 3 & 0 & 0 & 4 & 0 \\
\hline & $16.6 \%$ & $16.6 \%$ & $8.3 \%$ & $0 \%$ & $0 \%$ & $27.3 \%$ & $0 \%$ & $0 \%$ & $36.4 \%$ & $0 \%$ \\
\hline \multirow{2}{*}{ Control $(n=18)$} & 0 & 0 & 0 & 0 & 0 & 3 & 0 & 0 & 1 & 0 \\
\hline & $0 \%$ & $0 \%$ & $0 \%$ & $0 \%$ & $0 \%$ & $16.7 \%$ & $0 \%$ & $0 \%$ & $5.6 \%$ & $0 \%$ \\
\hline
\end{tabular}

\begin{tabular}{|l|l|l|}
\hline Supplemental Table 4. In vitro bleeding time of the cases. \\
\hline & Collagen-epinephrin $(\mathbf{n = 8 5 - 1 5 7} \mathbf{~ s n}) /($ No of cases) & Collagen-ADP ( $\mathbf{n = 6 5 - 1 2 5}$ sn) / (No of cases) \\
\hline Patients & $150.25 \pm 28.89(n=8)$ & $121.0 \pm 22.5(n=6)$ \\
\hline Parents & $131.9 \pm 35.5(n=16)$ & $110.3 \pm 74.1(n=8)$ \\
\hline Control & $129.2+28.8(n=9)$ & $88.3 \pm 12.2$ \\
\hline P (Patients-parents) & 0.293 & 0.233 \\
\hline P (Patients-control) & 0.293 & 0.031 \\
\hline P (Parents-control) & 0.293 & 1.000 \\
\hline
\end{tabular}




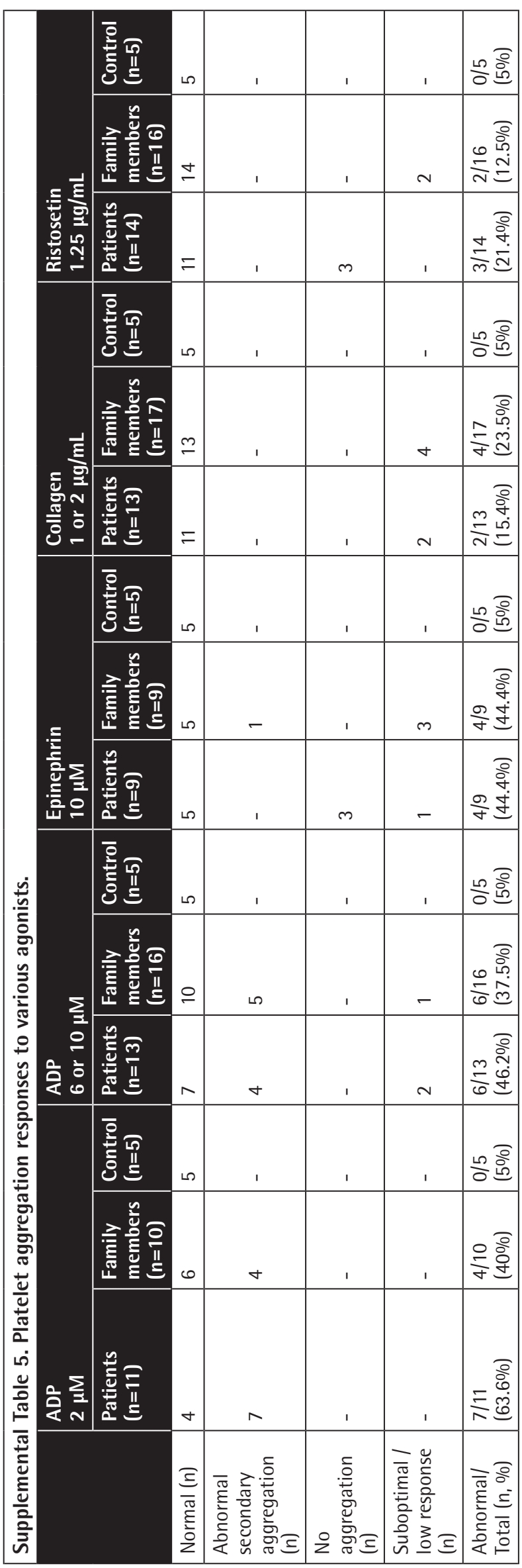

Additionally, studies of other colleagues showing enhanced stimulating effect of monocyte activation through toll-like receptors on TNF-alpha production $[12,13]$, and increased baseline cytokines including TNF-alpha in children with congenital neutropenia [14] also draw attention to the role of TNF-alpha and other inflammatory cytokines in congenital neutropenia.

Monocytes are activated by microbial products as well as molecules expressed or released by dying or stressed cells through toll-like receptors, interferon gamma, Th1 cells or complement fragments [15]; additionally removal mechanisms of necrotic and apoptotic cells may overlap [10]. Once activated, macrophages secrete TNF-alpha, IL-1, IL-6 and IL-12, the latter of which is also secreted by dendritic cells and stimulates IFN-gamma production by NK and T cells thereby exacerbating macrophage activation $[15,16]$. Hence, elevations of proinflammatory cytokines in congenital neutropenia were reported before $[11,14]$.

TNF-alpha which is mainly secreted by macrophages is a well known cytokine to give rise to apoptosis in neutrophils $[17,18]$, lymphocytes $[19,20]$, monocytes [21], and thrombocytes [22] in various conditions like sepsis, HLH [23], stroke, and ankylosing spondilitis and secreted mainly by macrophages and through TNF alpha and TNFR1 interaction.

Therefore, the factor that stimulates macrophage activation in our patients, none of whom had any major infection other than gingivitis or aphthous stomatitis at the time of evaluation, seems to be excessive apoptosis (thereby secondary necrosis) in the granulocytic lineage due to various mutations distrupting normal granulopoiesis. Apoptosis and secondary necrosis of other cell lines like lymphocytes and monocytes as shown by flow cytometry, and in megakaryocytes as shown by light microscopy are thought to be secondary to increased TNF-alpha through excessive macrophage activation.

\section{Text 2}

On the other hand, RCS in 25\% and 12.5\% of the evaluated patients and parents, documented by $\beta$-gal positivity of leukocytes may be another reason for quantitative abnormalities in T lymphocytes. That the patients with low CD3+ and CD4+ lymphocytes (sibling patients AG, ZG) were those with $\beta$-gal positivity of leukocytes showing RCS and with normal NK levels suggests a relationship between T-lymphopenia and RCS. Presence of immune activation in our patients documented by increased phagocytic activity in their bone marrow suggests that continual presence of circulating pro-inflammatory aforementioned factors secreted by activated macrophages had kept the immune system in a state of chronic low-level activation giving rise to an immunosenescence through loss of telomeric DNA with each S phase, and therefore a decline in the absolute number of $T$ and $B$ lymphocytes, with no change in overall lymphocyte count but a relative increase in NK cells [24] (in our patients we could not evaluate B lymphocytes). A set of mediators including inflammatory mediators secreted by senescent cells themselves contribute to the chronic inflammation [25] and the loss of telomeres. Likewise, a previous study of ours showed RCS ( $\beta$-gal positivity) of leukocytes in active autoimmune disorders [systemic lupus erythematasus (SLE), juvenile rhematoid arthritis (JRA), and immune thrombocytopenic purpura (ITP)], in all of which pro-inflammatory cytokines are high [26].

\section{Text 3}

\section{Dysmegakaryopoiesis and Hemorrhagic Diathesis}

In our patients one of the most prominent findings was abnormal megakaryopoiesis evidenced by naked megakaryocyte nuclei (NMN), 


\begin{tabular}{|c|c|c|c|c|}
\hline \multicolumn{5}{|c|}{ Supplemental Table 6. Laboratory parameters of the parents. } \\
\hline $\begin{array}{l}\text { Family of the patient } \\
\text { that is examined/ } \\
\text { mutation of the } \\
\text { patient }\end{array}$ & Parent/molecular genetics & $\begin{array}{l}\text { Lymphocyte } \\
\text { subsets in } \\
\text { comparison to } \\
\text { age matched } \\
\text { normal ranges }\end{array}$ & 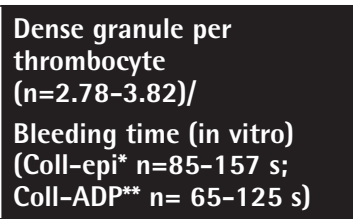 & Aggregation defect \\
\hline \multirow[t]{2}{*}{$\begin{array}{l}\text { Family of YF/ } \\
\text { HAX1 homozygous } \\
\text { c. } 130-131 \text { insA (p.W44X) }\end{array}$} & Mother/NA ${ }^{+}$ & $\begin{array}{l}\text { NK:25-50p } \\
\text { CD3:25-50p } \\
\text { CD4:<25p } \\
\text { CD8:25-50p } \\
\text { CD4/CD8:25-50p } \\
\end{array}$ & 3.2/coll-epi: $120 \mathrm{~s}$ & $\begin{array}{l}\text { No secondary aggregation with } 2 \text { and } 6 \mu \mathrm{M} \\
\mathrm{ADP} ; \text { hypoaggregation with epinephrin }(10 \\
\mu \mathrm{M} / \mathrm{mL}) \text {, normal aggregation with collagen } \\
(1 \mu \mathrm{g} / \mathrm{mL}) \text { and ristocetin }(1.25 \mathrm{mg} / \mathrm{mL})\end{array}$ \\
\hline & Father/NA ${ }^{+}$ & ND & 2.1/coll-epi: $152 \mathrm{~s}$ & $\begin{array}{l}\text { No secondary aggregation with } 2 \text { and } 6 \mu \mathrm{M} \\
\text { ADP; normal aggregation with epinephrin }(10 \\
\mu \mathrm{M} / \mathrm{mL}) \text {, collagen }(1 \mu \mathrm{g} / \mathrm{mL}) \text {, and ristocetin }(1.25 \\
\mathrm{mg} / \mathrm{mL})\end{array}$ \\
\hline \multirow[t]{2}{*}{$\begin{array}{l}\text { Family of MNY/AY } \\
\text { Both HAX1/ } \\
\text { Homozygous c.130- } \\
\text { 131insA (p.W44X) } \\
\end{array}$} & $\begin{array}{l}\text { Mother } \\
\text { HAX1 heterozygous c.130- } \\
\text { 131insA (p.W44X) }\end{array}$ & $\begin{array}{l}\text { NK<25p;CD3>75p } \\
\text { CD4:25-50p } \\
\text { CD8 }>75 p \\
\text { CD4/CD8<25p }\end{array}$ & 4/coll-epi: 154 s & ND \\
\hline & $\begin{array}{l}\text { Father } \\
\text { HAX1 heterozygous c.130- } \\
131 \text { insA (p.W44X)*** }\end{array}$ & $\begin{array}{l}\text { NK }<25 p \\
\text { CD3:50-75p } \\
\text { CD4 }>75 p \\
\text { CD8<25p } \\
\text { CD4/CD8 }>75 p\end{array}$ & 0.23/coll-epi:122 s & $\begin{array}{l}\text { Secondary aggregation defect and } \\
\text { and disaggregation with ADP }(10 \mu \mathrm{M}), \\
\text { hypoaggregation with collagen }(2 \mu \mathrm{g} / \mathrm{mL}) \text {, } \\
\text { normal aggregation with ristocetin } \\
(1.25 \mu \mathrm{g} / \mathrm{mL}) \text { (epinephrin not available) }\end{array}$ \\
\hline $\begin{array}{l}\text { Family of MK/ } \\
\text { HAX1 homozygous } \\
\text { c.130-131 insA (p.W44X) }\end{array}$ & Father/NAt & ND & ND/ND & $\begin{array}{l}\text { Hypoaggregation with ADP }(10 \mu \mathrm{M}) \text { and } \\
\text { collagen }(1 \mu \mathrm{g} / \mathrm{mL}) \text {, normal aggregation with } \\
\text { ristocetin }(1.25 \mu \mathrm{g} / \mathrm{mL})\end{array}$ \\
\hline \multirow[t]{2}{*}{$\begin{array}{l}\text { Family of EÇ/ } \\
\text { HAX1 homozygous } \\
\text { c. } 130-131 \text { insA (p.W44X) }\end{array}$} & $\begin{array}{l}\text { Mother } \\
\text { HAX1 heterozygous c.130- } \\
131 \text { ins } A^{* * *}\end{array}$ & $\begin{array}{l}\text { NK<25p } \\
\text { CD3>75p } \\
\text { CD4:50-75p } \\
\text { CD8:50-75p } \\
\text { CD4/CD8:50p }\end{array}$ & $\begin{array}{l}\text { 3.6/coll-epi:134 s; } \\
\text { Coll-ADP:103 s }\end{array}$ & $\begin{array}{l}\text { Normal aggregation with ADP }(10 \mu \mathrm{M}) \\
\text { collagen }(2 \mu \mathrm{g} / \mathrm{mL}) \text {, ristocetin }(1.25 \mathrm{mg} / \mathrm{mL})\end{array}$ \\
\hline & Father $N A^{*}$ & $\begin{array}{l}N K<25 p \\
C D 3: 25-50 p \\
C D 4>75 p \\
C D 8<25 p \\
C D 4 / C D 8>75 p\end{array}$ & $\begin{array}{l}\text { 3.5/coll-epi:151; coll- } \\
\text { ADP:80 s }\end{array}$ & $\begin{array}{l}\text { Normal aggregation with ADP }(10 \mu \mathrm{M}), \\
\text { collagen }(2 \mu \mathrm{g} / \mathrm{mL}) \text {, ristocetin } \\
(1.25 \mathrm{mg} / \mathrm{mL})\end{array}$ \\
\hline \multirow[t]{2}{*}{$\begin{array}{l}\text { Family of } \mathrm{HY} / \\
\text { HAX1 homozygous } \\
\text { c. } 130-131 \text { insA (p.W44X) }\end{array}$} & $\begin{array}{l}\text { Mother } \\
\text { HAX1 heterozygous c.130- } \\
131 \text { insA (p.W44X)*** }\end{array}$ & $\begin{array}{l}N K<25 p \\
C D 3>75 p \\
C D 4: 25-50 p \\
C D 8: 25-50 p \\
C D 4 / C D 8: 50 p\end{array}$ & $\begin{array}{l}\text { 4.5/coll-epi:76 s; } \\
\text { Coll-ADP:48 s }\end{array}$ & $\begin{array}{l}\text { Secondary aggregation defect and } \\
\text { disaggregation with ADP }(10 \mu \mathrm{M}) \text {, normal } \\
\text { aggregation with collagen }(2 \mu \mathrm{g} / \mathrm{mL}) \text {, ristocetin } \\
(1.25 \mathrm{mg} / \mathrm{mL})\end{array}$ \\
\hline & $\begin{array}{l}\text { Father } \\
\text { HAX1 heterozygous c.130- } \\
131 \text { insA (p.W44X) }\end{array}$ & $\begin{array}{l}\text { NK:25-50p } \\
\text { CD3:50-75p } \\
\text { CD4:25-50p } \\
\text { CD8:25-50p } \\
\text { CD4/CD8:50p }\end{array}$ & $\begin{array}{l}\text { 0.9/coll-epi: } 166 \text { s; coll-ADP: } \\
115 \mathrm{~s}\end{array}$ & $\begin{array}{l}\text { Secondary aggregation defect and } \\
\text { disaggregation with ADP }(10 \mu \mathrm{M}) \text {, } \\
\text { collagen }(2 \mu \mathrm{g} / \mathrm{mL}) \text {, ristocetin } \\
(1.25 \mathrm{mg} / \mathrm{mL})\end{array}$ \\
\hline $\begin{array}{l}\text { Family of OSK/MeK } \\
\text { G6PC3 homozygous, } \\
\text { c. } 194 \mathrm{~A}>\mathrm{C}(\mathrm{p} . \mathrm{E} 65 \mathrm{~A})\end{array}$ & Father/NAt & ND & $2.3 / \mathrm{ND}$ & $\begin{array}{l}\text { Normal aggregation with ADP }(2 \mu \mathrm{M}) \\
\text { hypoaggregation with epinephrin }(10 \mu \mathrm{M} / \mathrm{mL}) \\
\text { collagen }(1 \mu \mathrm{g} / \mathrm{mL}) \text { and ristocetin }(1.25 \mathrm{mg} / \mathrm{mL})\end{array}$ \\
\hline $\begin{array}{l}\text { Family of the patient } \\
\text { that is examined/ } \\
\text { mutation of the patient }\end{array}$ & Parent/molecular genetics & $\begin{array}{l}\text { Lymphocyte } \\
\text { subsets in } \\
\text { comparison to } \\
\text { age matched } \\
\text { normal ranges }\end{array}$ & $\begin{array}{l}\text { Dense granule per } \\
\text { thrombocyte } \\
(\mathrm{n}=2.78-3.82) / \\
\text { Bleeding time (in vitro) } \\
(\text { Coll-epi* } n=85-157 \mathrm{~s} \text {; Coll- } \\
\left.\text { ADP }^{* *} n=65-125 \mathrm{~s}\right)\end{array}$ & Aggregation defect \\
\hline \multirow[t]{2}{*}{$\begin{array}{l}\text { Family of RT/ } \\
\text { ELANE } \\
\text { Heterozygous } \\
\text { IVS4+5G }>\text { A }\end{array}$} & $\begin{array}{l}\text { Mother } \\
\text { No ELANE mutation**** }\end{array}$ & $\begin{array}{l}N K<25 p \\
\text { CD3:50-75p } \\
\text { CD4 }>75 p \\
\text { CD8<25p } \\
\text { CD4/CD8 }>75 p\end{array}$ & $\begin{array}{l}\text { 3.95/coll-epi: } 142 \text { s; coll- } \\
\text { ADP: } 96 \text { s }\end{array}$ & $\begin{array}{l}\text { Normal aggregation with ADP } \\
(2 \text { and } 6 \mu \mathrm{M}) \text {, epinephrin }(10 \mu \mathrm{M}), \\
\text { collagen }(1 \mu \mathrm{g} / \mathrm{mL}) \text {, ristocetin }(1.25 \mathrm{mg} / \mathrm{mL})\end{array}$ \\
\hline & $\begin{array}{l}\text { Father } \\
\text { No ELANE mutation**** }\end{array}$ & $\begin{array}{l}\text { NK }<25 p \\
\text { CD3 }>75 p \\
\text { CD4:25-50p } \\
\text { CD8:50-75p } \\
\text { CD4/CD8:25-50p }\end{array}$ & $\begin{array}{l}\text { 3.26/coll-epi: } 107 \text { s; coll- } \\
\text { ADP:65 s }\end{array}$ & $\begin{array}{l}\text { Normal aggregation with ADP } \\
(2 \text { and } 6 \mu \mathrm{M}) \text {, epinephrin }(10 \mu \mathrm{M}), \\
\text { collagen }(1 \mu \mathrm{g} / \mathrm{mL}) \text {, ristocetin }(1.25 \mathrm{mg} / \mathrm{mL})\end{array}$ \\
\hline
\end{tabular}




\begin{tabular}{|c|c|c|c|c|}
\hline \multicolumn{5}{|c|}{ Supplemental Table 6. Continued. } \\
\hline $\begin{array}{l}\text { Family of the patient } \\
\text { that is examined/ } \\
\text { mutation of the patient }\end{array}$ & Parent/molecular genetics & $\begin{array}{l}\text { Lymphocyte } \\
\text { subsets in } \\
\text { comparison to } \\
\text { age matched } \\
\text { normal ranges }\end{array}$ & $\begin{array}{l}\text { Dense granule per } \\
\text { thrombocyte } \\
\text { ( } \mathrm{n}=2.78-3.82) / \\
\text { Bleeding time (in } \\
\text { vitro) (Coll-epi* } \\
\mathrm{n}=85-157 \mathrm{~s} \text {; Coll- } \\
\text { ADP** } \mathrm{n}=65-125 \mathrm{~s})\end{array}$ & Aggregation defect \\
\hline $\begin{array}{l}\text { Family of BA } \\
\text { Unidentified mutation }\end{array}$ & Father//NA ${ }^{+}$ & $\begin{array}{l}N K<25 p \\
\text { CD3:50-75p } \\
\text { CD4>75p } \\
\text { CD8<25p } \\
\text { CD4/CD8 }>75 p\end{array}$ & 3.5/coll-epi: 97 s & $\begin{array}{l}\text { No secondary aggregation with } 2 \mu \mathrm{M} \text { ADP and } \\
\text { epinephrin }(10 \mu \mathrm{M} / \mathrm{mL}) \text { but normal aggregation with } 6 \\
\mu \mathrm{M} \text { ADP, collagen }(1 \mu \mathrm{g} / \mathrm{mL}) \text {, and ristocetin }(1.25 \mu \mathrm{g} / \mathrm{mL})\end{array}$ \\
\hline \multirow[t]{2}{*}{$\begin{array}{l}\text { Family of } A G / Z G \\
\text { Unidentified mutation }\end{array}$} & Mother//NA ${ }^{+}$ & $\begin{array}{l}N<25 p \\
C D 3: 50-75 p \\
C D 4>75 p \\
C D 8<25 p \\
C D 4 / C D 8>75 p\end{array}$ & 0.76/coll-epi: $134 \mathrm{~s}$ & $\begin{array}{l}\text { Normal aggregation with ADP } \\
(2 \text { and } 10 \mu \mathrm{M}) \text {, collagen }(2 \mu \mathrm{g} / \mathrm{mL}) \text {, ristocetin } \\
(1.25 \mathrm{mg} / \mathrm{mL})\end{array}$ \\
\hline & Father//NA ${ }^{+}$ & $\begin{array}{l}N K<25 p \\
C D 3>75 p \\
C D 4>75 p \\
C D 8<25 p \\
C D 4 / C D 8>75 p\end{array}$ & $\begin{array}{l}\text { 0.98/ coll-epi: } 193 \text { s; } \\
\text { coll-ADP>300 s }\end{array}$ & $\begin{array}{l}\text { Normal aggregation with ADP }(10 \mu \mathrm{M}) \text {, collagen }(2 \mu \mathrm{g} / \\
\mathrm{mL}) \text {, ristocetin }(1.25 \mathrm{mg} / \mathrm{mL})\end{array}$ \\
\hline \multirow[t]{2}{*}{$\begin{array}{l}\text { Family of NBÖ/ } \\
\text { Heterozygous } \\
\text { ELANE c. } 416 C>T\end{array}$} & $\begin{array}{l}\text { Mother } \\
\text { No ELANE mutation }{ }^{* *}\end{array}$ & ND & 1.8/coll-epi: $82 \mathrm{~s}$ & $\begin{array}{l}\text { Normal aggregation with ADP } \\
(2 \text { and } 6 \mu \mathrm{M}) \text {, epinephrin }(10 \mu \mathrm{M}), \\
\text { collagen }(1 \mu \mathrm{g} / \mathrm{mL}) \text {, ristocetin }(1.25 \mathrm{mg} / \mathrm{mL})\end{array}$ \\
\hline & $\begin{array}{l}\text { Father } \\
\text { No ELANE mutation }{ }^{* * *}\end{array}$ & ND & 2.0/coll-epi: 91 s & $\begin{array}{l}\text { No secondary aggregation with ADP }(2 \mu \mathrm{M}) \text { but normal } \\
\text { aggregation with ADP }(6 \mu \mathrm{M}) \text {, epinephrin }(10 \mu \mathrm{M}) \text {, } \\
\text { collagen }(1 \mu \mathrm{g} / \mathrm{mL}) \text {, ristocetin }(1.25 \mathrm{mg} / \mathrm{mL})\end{array}$ \\
\hline $\begin{array}{l}\text { Family of } A 0 \\
\text { Unidentified mutation }\end{array}$ & Mother/NA ${ }^{+}$ & ND & $\begin{array}{l}\text { 0.22/coll-epi: } 189 \mathrm{~s} ; \\
\text { coll-ADP:103 s }\end{array}$ & $\begin{array}{l}\text { Normal aggregation with ADP }(2 \text { and } 6 \mu \mathrm{M}) \text {, collagen } \\
(1 \mu \mathrm{g} / \mathrm{mL}) \text {, ristocetin }(1.25 \mathrm{mg} / \mathrm{mL}) \text {. Prolonged lag phase } \\
\text { with epinephrin }(10 \mu \mathrm{M})\end{array}$ \\
\hline
\end{tabular}

megakaryocyte emperipolesis, megakaryocytes with features of apoptosis, paraapoptosis, necrosis, and abnormalities in thrombocyte aggregation.

Naked megakaryocyte nuclei form after progressive folding of lobulated nucleus itself and then contracting (pyknosis), in order to reach the lowest volume that the megakaryocyte can occupy. The surrounding small rim of cytoplasm contains no characteristic MK granules or demarcation membranes. In physiological conditions, NMN are senescent cells which completed thrombocyte shedding and are few in normal bone marrow. However, large numbers of NMN in the bone marrow, like in myeloproliferative diseases and AIDS show defective maturation, a heavy intramedullary premature cell death of megakaryocytes and increased megakaryopoies [27, 28].

Emperipolesis $[29,30]$ is a random passage of one cell through the cytoplasm of another one with no physiological change in neither of them. It is most frequent in megakaryocytes and the most engulfed cell types are neutrophils and erythrocytes, as in our patients.

Naked megakaryocyte nuclei [27] and megakaryocytes with emperipolesis [29] were shown to display the features of paraapoptosis (non classical apoptosis).

While apoptosis is characterized by margination of condensed chromatin, nuclear fragmentation and formation of apoptotic bodies, paraapoptosis of megakaryocytes is characterized by cytoplasmic vacuolization due to mitochondrial swelling and distended demarcation membrane system (DMS), condensed nuclear chromatin with no early chromatin margination and no surface blebbing and apoptotic body formation. All paraapoptotic megakaryocytes were shown to have an intact, thickened peripheral zone which seemed to contain no functional cellular material, like organelles or DMS and their cytoplasm did not contain thrombocyte territories [31], like in our patients.

Additionally presence of many stage 1 megakaryocytes (megakaryoblasts), some of which are aberrantly releasing thrombocytes, unlike what is expected, also show dysmegakaryopoiesis [32].

That presence of nearly no normal megakaryocytes in our patients and that nearly all megakaryocytes displayed characteristics of NMN, emperipolesis or abnormal morphology like peripheral vacuolization (showing non-classical apoptosis: paraapoptosis and directly destructed megakaryocytes (showing necrosis) imply defective megakaryocyte maturation, a heavy intramedullary premature cell death of megakaryocytes and increased megakaryopoiesis.

Defective maturation in megakaryocytes is also expected to be due to the increased levels of aforementioned proinflammatory cytokines secreted by and after macrophage activation which can destroy the bone marrow microenvironment and hematopoietic stem cell niches [25] giving rise to hematopoietic stem cell dysfunction and dyshematopoiesis and thereby generalized 
dysplastic findings of bone marrow cells, as it is for the other bone marrow cells.

\section{Supplemental References}

1. Olcay L, Yetgin S, Okur H, Erdemli E. Rapid cell senescence and apoptosis in lymphocytes and granulocytes and absence of GM-CSF receptor in congenital dysgranulopoietic neutropenia. Leuk Res 2008;32:235-242.

2. Olcay L, Yetgin $S$, Erdemli $E$, Germeshausen $M$, Aktaş $D$, Büyükaşik $Y$, Okur H. Congenital dysgranulopoietic neutropenia. Pediatr Blood Cancer 2008;50:115-119.

3. Dykstra MJ. A Manual of Applied Techniques for Biological Electron Microscopy. New York, Plenum Press, 1993.

4. Olcay L, Yetgin S, Okur H, Erekul S, Tuncer M. Dysplastic changes in idiopathic thrombocytopenic purpura and the effect of corticosteroids to increase dysplasia and cause hyperdiploid macropolycytes. Am J Hematol 2000;65:99104.

5. Buyukasik Y, Karakus S, Goker H, Haznedaroglu IC, Ozatli D, Sayinalp N, Ozcebe OI, Dundar SV, Kirazli S. Rational use of the PFA-100 device for screening of platelet function disorders and von Willebrand disease. Blood Coagul Fibrinolysis 2002;13:349-353.

6. Olcay L, Erdemli E, Kesimer M, Büyükasik Y, Okur H, Kalkanoğlu HS, Coskun T, Altay $C$. High cystine in platelets from patients with nephropathic cystinosis: a chemical, ultrastructural, and functional evaluation. J Clin Pathol 2005;58:939-945.

7. Komarnichi M, Pietrzak I, Zozulinska M. Mepacrine-labeled platelet densebody number in patients with chronic uremia. Nephron 1988;50:306-307.

8. Pintado $\mathrm{T}$, Maldonado JE. Ultrastructure of platelet aggregation in refractory anemia and myelomonocytic leukemia. I. Ultrastructure of aggregation in normal controls and general defects in refractory anemia and myelomonocytic leukemia. Mayo Clin Proc 1976;51:379-392.

9. Pintado T, Maldonado JE. Ultrastructure of platelet aggregation in refractory anemia and myelomonocytic leukemia. II. Individual platelet abnormalities: Thrombasthenia-like platelets, surface defects, and dissociation phenomena. Mayo Clin Proc 1976;51:443-451.

10. Poon IK, Lucas CD, Rossi AG, Ravichandran KS. Apoptotic cell clearance: basic biology and therapeutic potential. Nat Rev Immunol 2014;14:166-180.

11. Olcay $L$, Ünal Ş, Onay $H$, Erdemli $E$, Öztürk $A$, Billur D, Metin $A$, Okur $H$, Yıldırmak $Y$, Büyükaşık $Y$, İkincioğulları A, Yılmaz-Falay $M$, Özet $G$, Yetgin S. Granulocytic and non granulocytic lineages in children with congenital neutropenia and their non neutropenic parents: Biochemical, functional, morphological and genetic evaluation. Haematologica 1012;97(Suppl 3):065a (abstract).

12. Koval'chuk LV, Khoreva MV, Nikonova AS, Finogenova NA, Mamedova EA, Polovtseva TV, Fetisova Lla, Gracheva LA, Goldyreva NG. Toll-like receptormediated functional activity of mononuclear cells in children with neutropenia. Zh Mikrobiol Epidemiol Immunobiol 2010;2:64-68.

13. Bohn G, Hardtke-Wolenski M, Zeidler C, Maecker B, Sauer M, Sykora KW, Grigull L, Welte K, Klein C. Lethal graft-versus-host disease in congenital neutropenia caused by 14 deficiency after allogeneic bone marrow transplantation from an HLA-identical sibling. Pediatr Blood Cancer 2008;51:436-438.

14. Shitara T, Yugami S, ljima H, Sotomatu M, Kuroume T. Cytokine profile during high-dose rhG-CSF therapy in severe congenital neutropenia. Am J Hematol 1994;45:58-62.
15. Abbas AK, Lichtman AH, Pillai S. Innate immunity. In: Cellular and Molecular Immunology. 8th ed. Canada, Elsevier Saunders, 2015:51-86.

16. Abbas AK, Lichtman AH, Pillai S. Differentiation and functions of CD4+ effector T cells. In: Cellular and Molecular Immunology. 8th ed. Canada, Elsevier Saunders, 2015:213-230.

17. Geering B, Simon HU. A novel signaling pathway in TNF $\alpha$-induced neutrophil apoptosis. Cell Cycle 2011;10:2821-2822.

18. Ugan $Y$, Nazıroğlu $M$, Şahin $M$, Aykur M. Anti-tumor necrosis factor alpha (Infliximab) attenuates apoptosis, oxidative stress, and calcium ion entry through modulation of cation channels in neutrophils of patients with ankylosing spondylitis. J Membr Biol 2016;249:437-447.

19. Bommhardt U, Chang KC, Swanson PE, Wagner TH, Tinsley KW, Karl IE, Hotchkiss RS. Akt decreases lymphocyte apoptosis and improves survival in sepsis. J Immunol 2004;172:7583-7591.

20. Hotchkiss RS, Tinsley KW, Karl IE. Role of apoptotic cell death in sepsis. Scand $\mathrm{J}$ Infect Dis 2003;35:585-592.

21. Kawakami Y, Tsukimoto M, Kuwabara K, Fujita T, Fujino 0, Kojima S, Fukunaga $Y$. Tumor necrosis factor- $\alpha$-induced mononuclear cell death may contribute to polymorphonuclear cell predominance in the cerebrospinal fluid of patients with bacterial meningitis. J Nippon Med Sch 2011;78:360-366.

22. Cevik O, Adiguzel Z, Baykal AT, Somay G, Sener A. The apoptotic actions of platelets in acute ischemic stroke. Mol Biol Rep 2013;40:6721-6727.

23. Kawada J, Kimura $H$, Shibata $Y$, Hara $S$, Hoshino $Y$, Kojima $S$, Nishikawa $\mathrm{K}$, Morishima T. Evaluation of apoptosis in Epstein-Barr virus-associated hemophagocytic lymphohistiocytosis. J Med Virol 2006;78:400-407.

24. McElhaney JE, Effros RB. Immunosenescence: what does it mean to health outcomes in older adults? Curr Opin Immunol 2009;21:418-424.

25. Freund A, Orjalo AV, Desprez PY, Campisi J. Inflammatory networks during cellular senescence: Causes and consequences. Trends Mol Med 2010;16:238246.

26. Olcay L, Billur D, Erdemli E, Baskin SE, Balci HF, Yetgin S. Myelodysplastic features and cellular senescence in autoimmune disorders: a pilot study on patients with collagen tissue disorders and immune thrombocytopenic purpura. Turk J Med Sci 2015;45:742-744.

27. Thiele J, Lorenzen J, Manich B, Kvasnicka HM, Zirbes TK, Fischer R. Apoptosis (programmed cell death) in idiopathic (primary) osteo-/myelofibrosis: naked nuclei in megakaryopoiesis reveal features of para-apoptosis. Acta Haematol 1997; $97: 137-143$.

28. Olcay L, Tuncer AM, Okur H, Erdemli E, Uysal Z, Cetin M, Duru F, Cetinkaya DU. Excessive naked megakaryocyte nuclei in myelodysplastic syndrome mimicking idiopathic thrombocytopenic purpura: a complicated pre- and post-transplantation course. Pediatr Hematol Oncol 2009;26:387-397.

29. Centurione L, Di Baldassarre A, Zingariello M, Bosco D, Gatta V, Rana RA, Langella $V$, Di Virgilio A, Vannucchi AM, Migliaccio AR. Increased and pathologic emperipolesis of neutrophils within megakaryocytes associated with marrow fibrosis in GATA-1 (low) mice. Blood 2004;104:3573-3580.

30. Aslan D, Yetgin S. Megakaryocyte emperipolesis in a child with chronic neutropenia: an unusual coexistence. Turk J Pediatr 2001;43:255-256.

31. Houwerzijl EJ, Blom NR, van der Want JJ, Esselink MT, Koornstra JJ, Smit JW,

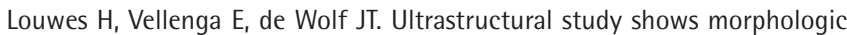
features of apoptosis and para-apoptosis in megakaryocytes from patients with idiopathic thrombocytopenic purpura. Blood 2004;103:500-506.

32. Erber WN, Jacobs A, Oscier DG, O'hea AM, Mason DY. Circulating micromegakaryocytes in myelodysplasia. J Clin Pathol 1987;40:1349-1352. 